UNIVERSIDADE DE SÃO PAULO

FACULDADE DE ECONOMIA, ADMINISTRAÇÃO E CONTABILIDADE DEPARTAMENTO DE ADMINISTRAÇÃO PROGRAMA DE PÓS-GRADUAÇÃO EM ADMINISTRAÇÃO

COCRIAÇÃO DE VALOR: CONCEITOS E IMPLICAÇÕES VISTOS SOB A ÓTICA DA EDUCAÇÃO A DISTÂNCIA NO BRASIL

Danielle Daffre Carvalho

Orientadora: Profa. Dra. Maria Aparecida Gouvêa

SÃO PAULO 
Prof. Dr. Marco Antonio Zago Reitor da Universidade de São Paulo

Prof. Dr. Adalberto Américo Fischmann

Diretor da Faculdade de Economia, Administração e Contabilidade

Prof. Dr. Roberto Sbragia

Chefe do Departamento de Administração

Prof. Dr. Moacir de Miranda Oliveira Júnior Coordenador do Programa de Pós-Graduação em Administração 


\section{COCRIAÇÃO DE VALOR: CONCEITOS E IMPLICAÇÕES VISTOS SOB A ÓTICA DA EDUCAÇÃO A DISTÂNCIA NO BRASIL}

Tese apresentada ao Programa de PósGraduação em Administração do Departamento de Administração da Faculdade de Economia, Administração e Contabilidade da Universidade de São Paulo, como requisito parcial para a obtenção do título de Doutor em Ciências.

Orientadora: Profa. Dra. Maria Aparecida Gouvêa

Versão Corrigida

versão original disponível na Biblioteca da Faculdade de Economia, Administração e Contabilidade

\section{SÃo PAUlO}


FICHA CATALOGRÁFICA

Elaborada pela Seção de Processamento Técnico do SBD/FEA/USP

Carvalho, Danielle Daffre

Cocriação de valor: conceitos e implicações vistos sob a ótica da educação a distância no Brasil / Danielle Daffre Carvalho. - São Paulo, 2017.

$164 \mathrm{p}$.

Tese(Doutorado) - Universidade de São Paulo, 2017.

Orientador: Maria Aparecida Gouvêa.

1. Educação a distância 2. Marketing de serviços 3. Marketing educacional 4. Estatística aplicada 5. Modelagem de equações estruturais I. Universidade de São Paulo. Faculdade de Economia, Administração e Contabilidade. II. Título.

CDD - 371.334 


\section{AGRADECIMENTOS}

Agradeço à minha orientadora, professora Maria Aparecida Gouvêa, por sua confiança depositada em mim desde o primeiro dia que nos falamos.

Aos meus pais, agradeço por estarem presentes não apenas em cada fase do doutorado, mas em cada momento relevante da minha vida, acreditando e encorajando os meus passos.

À minha irmã, agradeço pelo carinho e orgulho demonstrados sempre.

À minha avó, tios e primos, agradeço pelo apoio incondicional nos momentos mais difíceis.

Agradeço aos professores que tive durante o doutorado, em especial aos professores José Afonso Mazzon e Abraham Sin Oih Yu, que, mesmo inconscientemente, me impulsionaram a ser uma melhor profissional.

À Eliane e Paula, amigas de graduação, de mestrado, de trabalho, de vida, agradeço o interesse constante e a companhia nos momentos certos.

Agradeço à Luciana, Natalia e Liana, que sempre me incentivaram e demonstraram interesse desde quando o tema de pesquisa ainda era um embrião.

Agradeço aos amigos que fiz na FEA-USP, Patrícia, Mariana, Vitor, Leonardo, Camila, Rodolfo, Roberto, Elaine, Daniel, Greice, Sandra, Alexandre e tantos outros, cuja amizade tornou todo o processo muito mais tranquilo e divertido.

Aos meus colegas da SD\&W, agradeço pelo incentivo e, especialmente à Ana Lúcia, agradeço por todo apoio e contribuição.

Agradeço aos profissionais e empresas que, acreditando no trabalho, compartilharam seus dados, tornando possível a realização da pesquisa. Em especial, agradeço ao Daniel Infante pela prontidão e disponibilidade que sempre demonstrou.

Por fim, agradeço a todos que confiaram na pesquisa e responderam o questionário. 

“(...) because we're curious and curiosity keeps leading us down new paths" Walt Disney 



\section{RESUMO}

Modalidade de ensino em crescimento no Brasil desde o início dos anos 2000 e com expectativa de contínua expansão, especialmente em função da cada vez maior facilidade de comunicação, seja via Internet, seja via celular ou tablet, a educação a distância (EaD) permite que indivíduos de áreas remotas ou aqueles com pouca disponibilidade de rotina regular para frequentar um curso tradicional, possam obter um diploma superior. Do ponto de vista das instituições de ensino, porém, as altas taxas de evasão são um obstáculo à manutenção e ampliação da oferta desta tipologia de curso. Para que haja a queda destas taxas, é necessário aumentar a lealdade dos estudantes e, para tanto, o valor percebido no curso, que, no caso da educação, faz sentido supor que seja criado entre alunos e universidade; isto porque, além de haver a necessidade de ambos os agentes para a prestação de serviço, o aluno possui papel fundamental para o sucesso do que se oferece (qualificação acadêmica). A literatura acadêmica do setor de serviços indica que, apesar de existir relação entre [cocriação de] valor e lealdade, esta, em geral, se apresenta mediada por qualidade e/ou satisfação. É neste contexto que este trabalho está inserido, apresentando como objetivo identificar os aspectos de cocriação de valor determinantes para a qualidade percebida e lealdade, com foco em educação a distância, por meio de uma pesquisa quantitativa com estudantes desta modalidade de ensino. Esta pesquisa foi antecedida pela exploração do tema com especialistas do setor que contribuíram com seus conhecimentos e experiências. Para a pesquisa quantitativa foi enviado questionário online de autopreenchimento para endereço eletrônico de estudantes de graduação $\mathrm{EaD}$ fornecidos por parceria com faculdades privadas e empresa de pesquisa voltada à educação. Ao final, foram obtidas 400 respostas válidas, usadas para entender o comportamento do aluno perante cocriação de valor e suas relações com demais dimensões de interesse (qualidade percebida, satisfação e lealdade). Duas vertentes mostraram-se relevantes na composição da cocriação de valor: coprodução, que engloba o compartilhamento de conhecimento, a interação faculdade-aluno e transparência na transmissão de valores e interesses da faculdade; e valor em uso, refletindo a experiência, o relacionamento e a capacidade de personalização do serviço educacional. Como era suposto, a cocriação mostrou-se influente na explicação dos construtos e tem a imagem da faculdade como uma dimensão importante em sua explicação. Quando observadas as relações entre variáveis latentes segundo o perfil do aluno, encontra-se que aqueles pertencentes à Geração Y são os que mais condicionam sua satisfação e lealdade à participação na criação do valor.

Palavras-chave: Educação a distância. Cocriação de valor. Lealdade. Evasão escolar. Ensino superior 



\begin{abstract}
Growing type of education in Brazil since the early 2000s and with expectations of continued expansion, especially given the increasing ease of communication, whether via the Internet, whether via mobile phone or tablet, distance education (DE) allows individuals from remote areas or those with limited availability of regular routine to attend a traditional course, get a higher degree. From the perspective of educational institutions, however, the high dropout rates are an obstacle to the maintenance and expansion of supply of this type of course. In order to make these rates fall, it is necessary to increase the loyalty of students and, therefore, the perceived value, which in the case of education, it makes sense to assume created between students and university; this is because in addition to be a need for both agents to provide service, the student has fundamental role in the success of what is offered (academic qualification). The academic literature in the service sector indicates that although there is a relationship between [co-creation of] value and loyalty, this relation is usually presents mediated by quality and/or satisfaction. In this context, this work is inserted, aiming to identify the aspects of value co-creation that are determinants for perceived quality and loyalty, focusing on distance education, through a quantitative survey of students of this type of education. This research was preceded by an exploration of the theme with specialists of the sector who contributed with their knowledge and experiences. For the survey, an online self-completion questionnaire was sent to the e-mail of undergraduate students provided by a partnership with private colleges and a research company focused on education. In the end, 400 valid answers were obtained, used to understand the student's behavior in relation to value creation and their relationships with other dimensions of interest (perceived quality, satisfaction and loyalty). Two aspects have been relevant in the composition of value co-creation: co-production, which includes knowledge sharing, college-student interaction and transparency in the transmission of values and interests of the college; and value-in-use, reflecting the experience, the relationship and the capacity of personalization on the educational service. As was supposed, co-creation has proved to be influential in the explanation of constructs, and the image of college is an important dimension in its explanation. When the relationships between latent variables were observed according to the profile of the student, it was found that those belonging to Y Generation are the ones that present their satisfaction and loyalty conditioned to participation in the creation of value.
\end{abstract}

Keywords: Distance education. Value co-creation. Loyalty. University dropout. Higher education 



\section{LISTA DE ABREVIATURAS E SIGLAS}

ABED: Associação Brasileira de Educação a Distância

ACSI: American Customer Satisfaction Index

Assim: Assimetria

AVE: Average Variance Extracted

CC: Confiabilidade Composta

Curt: Curtose

CV: Coeficiente de Variação

DART: Diálogo, acesso, risco-benefício, transparência

DP: Desvio Padrão

FIES: Fundo de Financiamento Estudantil

G-D logic: Goods-Dominant Logic

HTMT: Heterotrait-Monotrait Ratio

IBGE: Instituto Brasileiro de Geografia e Estatística

INEP: Instituto Nacional de Estudos e Pesquisas Educacionais Anísio Teixeira

LDB: Lei de Diretrizes e Bases da Educação

MEB: Movimento de Educação de Base

Med: Mediana

PIB: Produto Interno Bruto

PLS-MGA: PLS-SEM Multigroup Analysis

PLS-SEM: Partial Least Squares Structural Equation Modeling

PNAD: Pesquisa Nacional por Amostra de Domicílios

S logic: Service Logic

S-D logic: Service-Dominant Logic

VAF: Variance accounted for

VIF: Variance inflator factor 



\section{LISTA DE TABELAS}

Tabela 1 - Número de cursos, vagas e matrículas: EaD e presencial, 2000 a 2015 ............31

Tabela 2 - Número de matrículas e concluintes: EaD e presencial, 2000 a 2015 ...............33

Tabela 3 - Percentual de cursos de graduação oferecidos por escolas particulares: EaD e

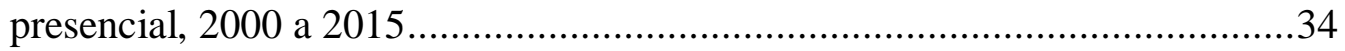

Tabela 4 - Distribuição de alunos por faixa etária: EaD e presencial, 2015 ......................37

Tabela 5 - Número de alunos segundo situação de matrícula: EaD e presencial, 2015 ......37

Tabela 6 - Dimensões referentes à cocriação de valor segundo Ranjan e Read (2016) ......57

Tabela 7 - Dimensões referentes a qualidade percebida, satisfação e lealdade ...................70

Tabela 8 - Atributos e fontes para cocriação de valor ...................................................... 72

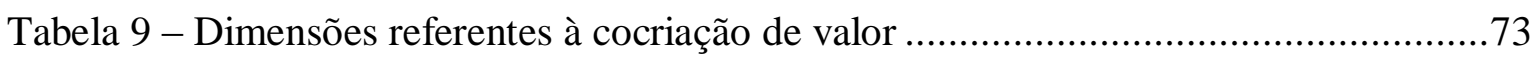

Tabela 10 - Critérios para definição de modelo formativo e modelo reflexivo ...................75

Tabela 11 - Perfil demográfico da amostra.................................................................92

Tabela 12 - Perfil da amostra referente à situação estudantil ......................................93

Tabela 13 - Estatísticas descritivas dos itens dos construtos ..........................................96

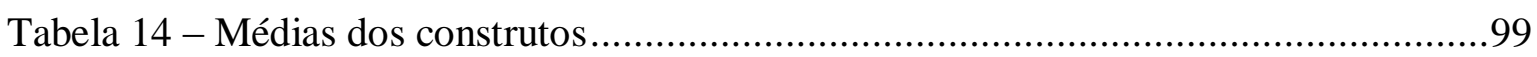

Tabela 15 - Avaliação do critério de Fornell-Larcker - primeira execução...................... 102

Tabela 16 - Avaliação do critério de Fornell-Larcker - pré-validação convergente e

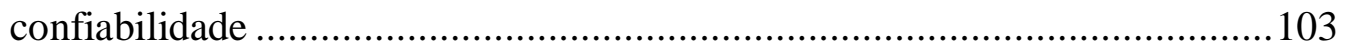

Tabela 17 - Cargas fatoriais - pré-validação convergente e confiabilidade ......................104

Tabela 18 - Estatística HTMT - pré-validação convergente e confiabilidade .................. 105

Tabela 19 - Medidas de validade convergente e confiabilidade dos indicadores ..............106

Tabela 20 - Avaliação de multicolinearidade (VIF) entre construtos de $1^{\mathrm{a}}$ ordem referentes

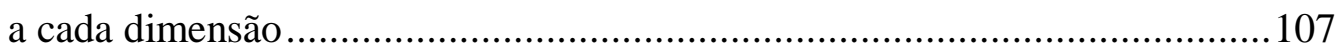

Tabela 21 - Avaliação de multicolinearidade (VIF) para o modelo proposto ...................112

Tabela 22 - Valores de $\mathrm{R}^{2}$ e $\mathrm{Q}^{2}$ para variáveis latentes endógenas .................................115

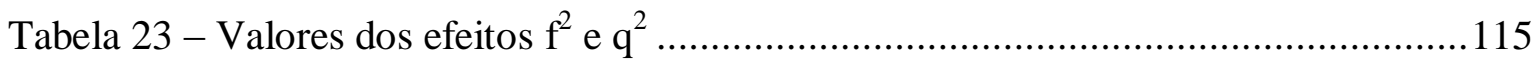

Tabela 24 - Estatísticas descritivas dos itens de imagem e comprometimento ................117

Tabela 25 - Medidas de validade convergente, discriminante e confiabilidade dos indicadores para o modelo alternativo .................................................... 119

Tabela 26 - Avaliação de multicolinearidade (VIF) para modelo alternativo ...................121

Tabela 27 - Medidas de avaliação do modelo estrutural alternativo................................126 
Tabela 28 - Comparação das relações estruturais segundo grupos de interesse

Tabela 29 - Avaliação do critério de Fornell-Larcker para o modelo final ......................161

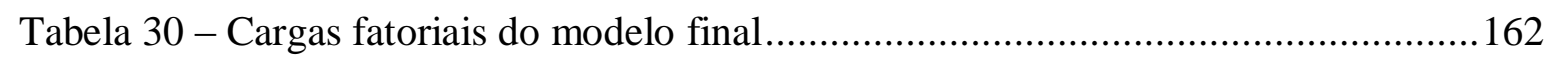

Tabela 31 - Estatística HTMT para o modelo final...................................................... 163

Tabela 32 - Medidas de validade convergente e confiabilidade dos indicadores para o modelo final............................................................................. 163 


\section{LISTA DE FIGURAS}

Figura 1 - Distribuição dos alunos por regiões e localidade: EaD e presencial, 2015 ........35 Figura 2 - Distribuição dos alunos por gênero: EaD e presencial, cursos em geral e

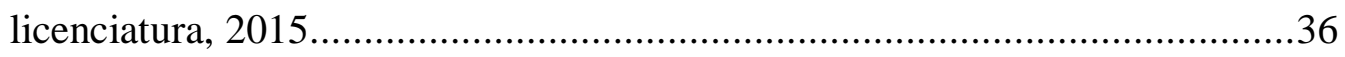

Figura 3 - Modelo de cocriação de experiência de relacionamento com a marca ..............53

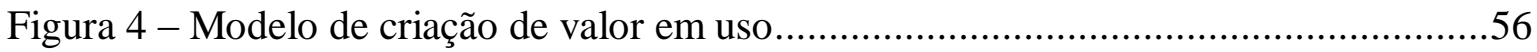

Figura 5 - Cocriação de valor: modelo de mensuração (formativo-formativo) ..................59

Figura 6 - Modelo proposto para relacionamento entre cocriação de valor, qualidade percebida, satisfação e lealdade - visão macro .........................................68

Figura 7 - Qualidade percebida: modelo de mensuração ............................................. 70

Figura 8 - Cocriação de valor: modelo de mensuração (reflexivo-formativo) ...................76

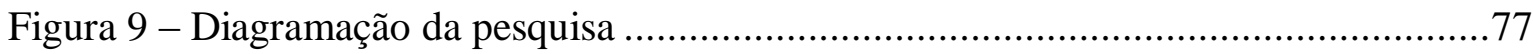

Figura 10 - Modelo de mensuração para qualidade percebida ..................................... 108

Figura 11 - Modelo de mensuração para cocriação de valor ..........................................109

Figura 12 - Avaliação do modelo de mensuração - primeira execução...........................110

Figura 13 - Avaliação do modelo de mensuração - execução final.................................111

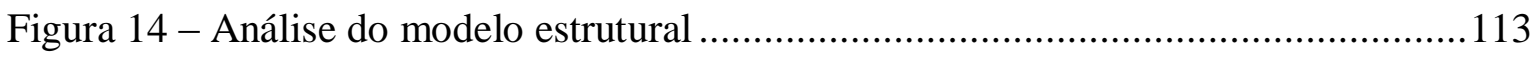

Figura 15 - Modelo alternativo - visão macro ............................................................. 118

Figura 16 - Modelo de mensuração para comprometimento ..........................................120

Figura 17 - Avaliação do modelo de mensuração alternativo ........................................121

Figura 18 - Análise do modelo estrutural alternativo................................................... 122

Figura 19 - Lealdade como construto consequente....................................................123

Figura 20 - Modelo estrutural cocriação de valor e lealdade, mediado por

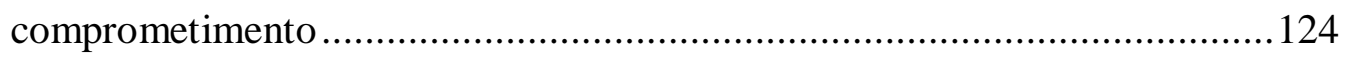

Figura 21 - Modelo estrutural satisfação e lealdade, mediado por comprometimento .....125

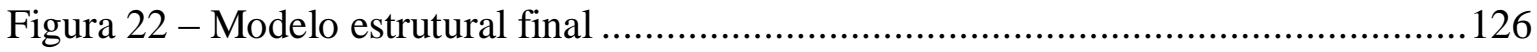





\section{SUMÁRIO}

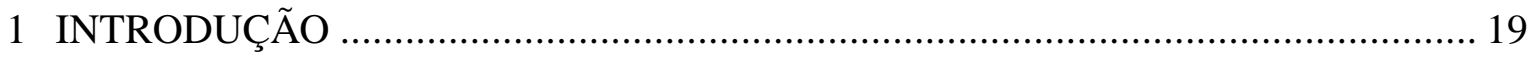

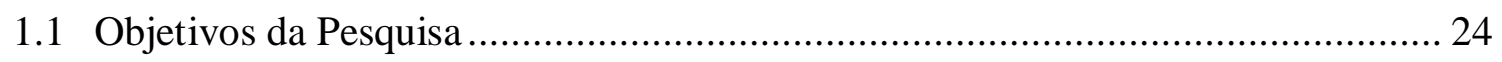

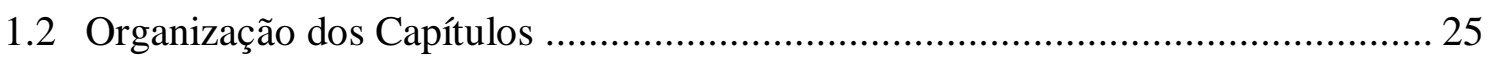

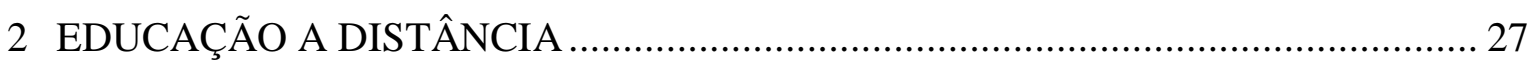

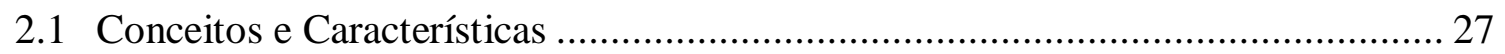

2.2 Números da Educação a Distância no Ensino Superior Brasileiro ........................ 31

2.3 Educação a Distância no Ensino Superior: Perfil do Aluno Brasileiro .................. 35

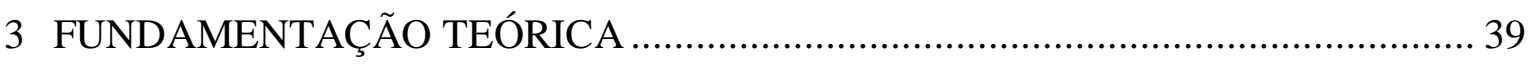

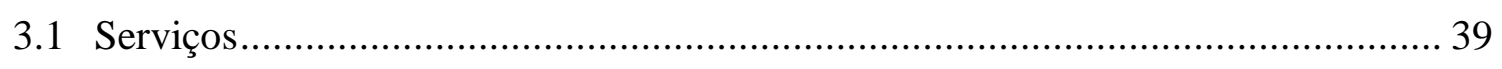

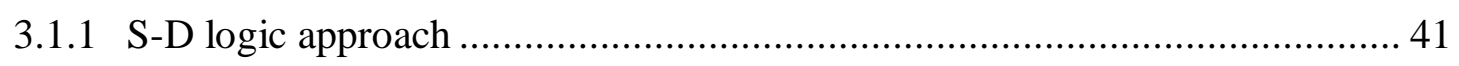

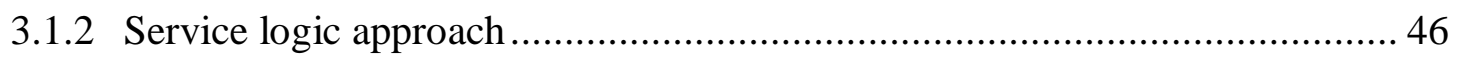

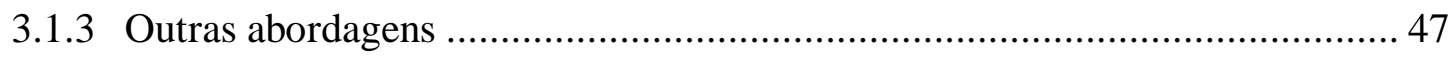

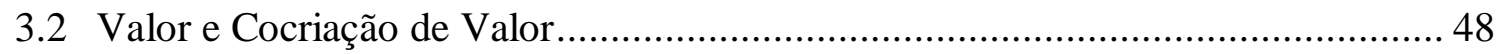

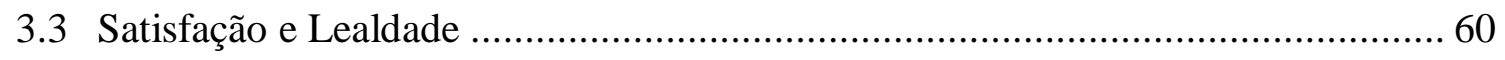

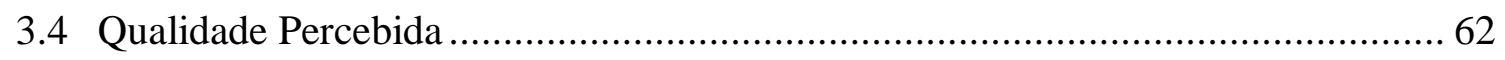

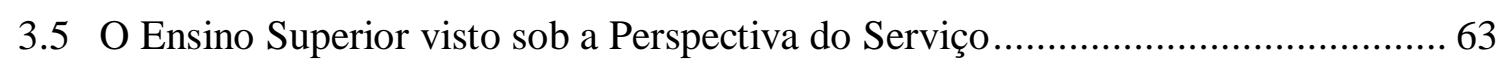

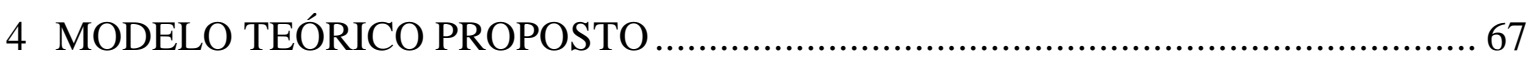

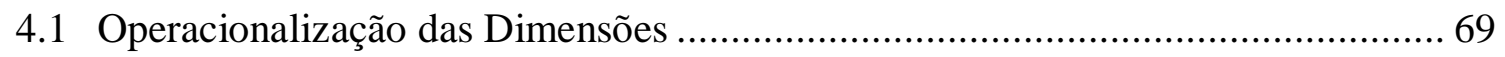

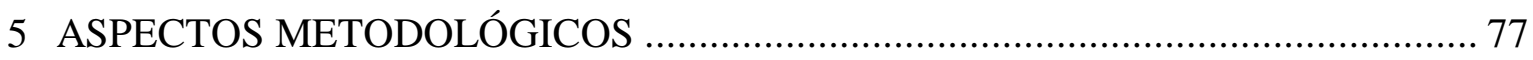

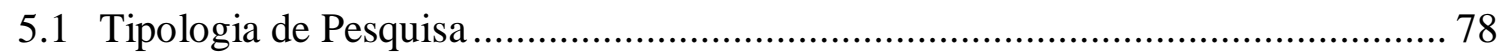

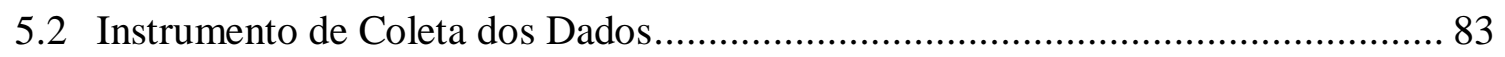

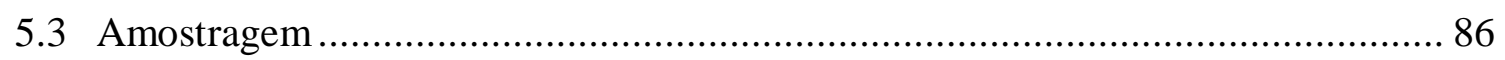

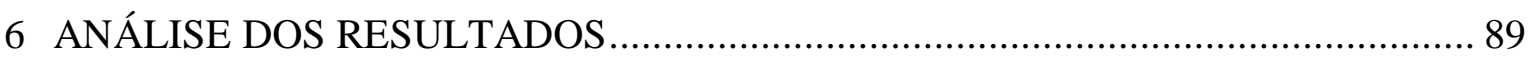

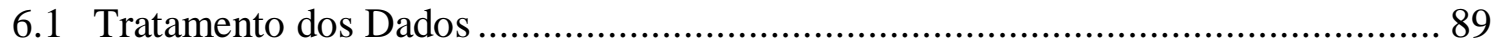

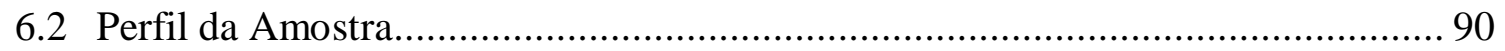

6.3 Modelo de Equações Estruturais: PLS-SEM ................................................... 100

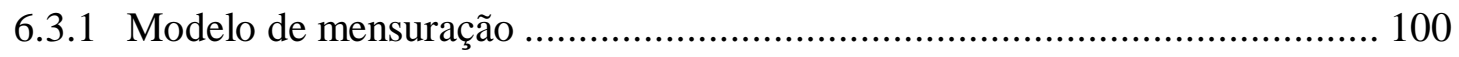

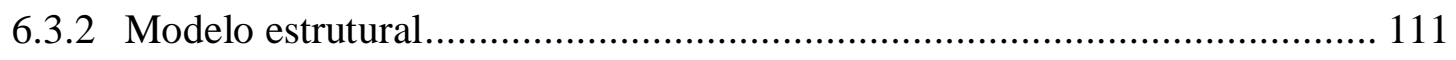

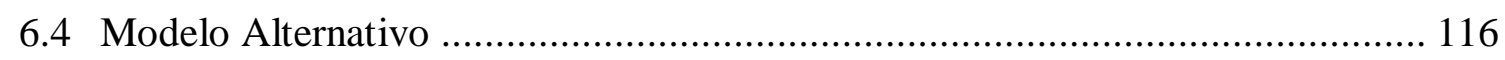

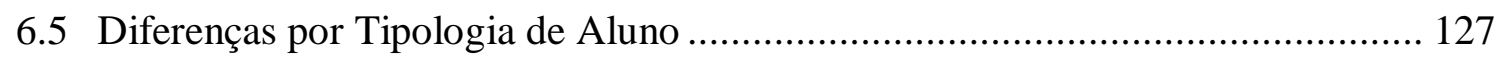

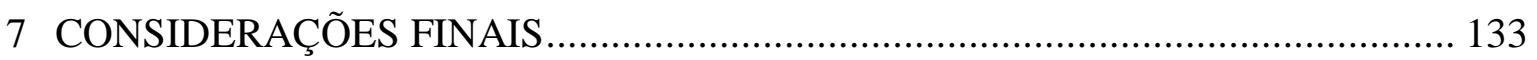




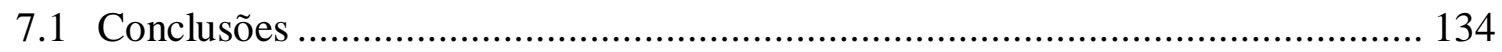

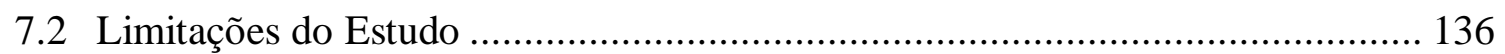

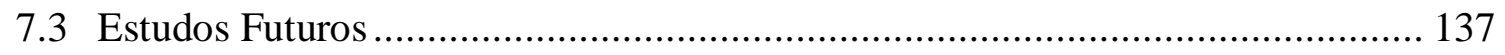

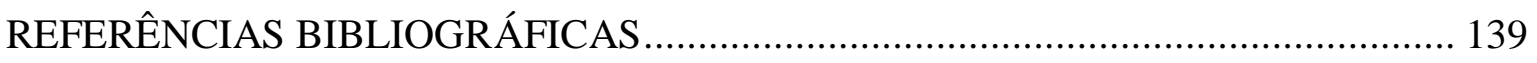

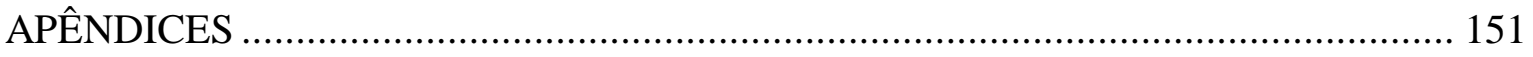

Apêndice A - Roteiro de Pesquisa Qualitativa.................................................... 151

Apêndice B - Instrumento de Coleta de Dados ......................................................... 153

Apêndice C - Tabelas de Validade Discriminante, Convergente e Medidas de

Confiabilidade para Modelo Final ............................................................................ 161 


\section{INTRODUÇÃO}

A educação a distância $(\mathrm{EaD})$ foi estruturada a partir do desenvolvimento de tecnologias de transporte e comunicação, permitindo o aprendizado mesmo quando professores e alunos estão em localizações distintas e apresentou evolução conforme o surgimento de inovações tecnológicas, como rádio e telégrafo na primeira metade do século $\mathrm{XX}$, televisores a partir da década de 1950, computadores no final do século XX e tablets e celulares no início do século XXI (Keegan, 1996; Fuegen, 2012; Saboia, Viva \& Vargas, 2013).

Com a massificação da Internet, ocorreu também a expansão dos cursos a distância em todo o mundo, em função da facilidade de comunicação e agilidade de interação com professores e colegas de turma, aproximando a atmosfera do EaD à do ensino tradicional (presencial).

Em 2005, o Ministério da Educação (MEC) criou a Universidade Aberta do Brasil (UAB), programa que apresenta a "ampliação e interiorização da oferta de cursos e programas de educação superior, por meio da educação a distância, com prioridade à formação de professores e outros profissionais da educação básica da rede pública" como principal objetivo.

Conforme ressaltado por Mantovani (2012), este modelo de educação a distância adotado permitiu que pessoas de áreas remotas e que, provavelmente, não teriam acesso a um diploma superior caso precisassem frequentar aulas presenciais, tivessem a possibilidade de obter uma graduação, gerando, como consequência, maior desenvolvimento para essas áreas. Mesmo em casos em que o curso exige contato presencial esporádico do aluno, são designados locais (polos) próximos à residência dos alunos, não necessariamente em grandes centros (onde está a maior concentração das faculdades tradicionais).

Em seu estudo, Mantovani (2012) aponta diferenças demográficas entre os alunos de graduação do $\mathrm{EaD}$ e dos cursos presenciais brasileiros, com o primeiro destacando-se pelo número de mulheres de mais idade. Esta diferenciação pode ser explicada por alguns motivos, como tipologia de cursos oferecidos em cada modalidade de ensino - EaD 
apresentam, proporcionalmente, grande quantidade de vagas nas áreas de humanas e licenciaturas, cadeiras tradicionalmente com maior número de mulheres -, maior flexibilidade aos horários da família e, especialmente no caso das mais velhas, necessidade de obtenção de diploma superior após entrada no mercado de trabalho.

Dados mais recentes divulgados pelo Ministério da Educação mostram que, no Brasil, o número de matriculados em cursos de graduação no EaD foi de 114.642 em 2005 para 1.393.752 em 2015 (Instituto Nacional de Estudos e Pesquisas Educacionais Anísio Teixeira [INEP], 2016), um crescimento de $1.116 \%$ em 10 anos. Para efeito de comparação, durante o mesmo período, a educação tradicional - presencial - apresentou crescimento de $49 \%$ no número de matrículas. Embora o mercado educacional tradicional esteja mais maduro sendo, portanto, esperado um crescimento em menor ritmo, a velocidade de evolução do $\mathrm{EaD}$, mesmo com alguns mitos que o cercam, especialmente no que tange à qualidade, como supor que cursos online são mais fáceis do que os equivalentes tradicionais (Mantovani, 2012), indica o quanto este tópico encontra-se em voga. Importante destacar que, apesar de estar em um compasso mais lento do que o visto entre 2005 e 2008 (com crescimentos a taxas de mais de $81 \%$ ao ano), não há motivos para crer em estagnação da atividade tão em breve: o crescimento foi de 4\% entre 2014 e 2015 , anos de arrefecimento da economia brasileira (Villas Bôas \& Patu, 2016), o dobro do apresentado pelo ensino tradicional.

Segundo relatório analítico da aprendizagem a distância no Brasil desenvolvido pela Associação Brasileira de Educação a Distância (ABED) em parceria com a Fundação Getúlio Vargas e o Grupo Uninter (ABED, 2014) com 309 instituições de ensino, o maior obstáculo enfrentado pelas universidades na execução de cursos a distância no país referese à evasão, cuja taxa varia de acordo com o tipo de curso avaliado; para aqueles autorizados pelo MEC (foco desta pesquisa) a evasão foi de 16,94\% em 2013, com variação entre 14,83\% para o caso de cursos regulamentados semipresenciais e 19,06\% para cursos regulamentados totalmente a distância.

Brambilla e Damacena (2012) sugerem que a evasão em instituições de ensino superior está [inversamente] relacionada à lealdade dos alunos perante este estabelecimento. 
Encontrar meios de aumentar a lealdade pode, assim, promover algum tipo de vantagem competitiva para a Universidade decorrente do aumento da retenção do corpo discente.

A definição de lealdade é discutida por Aksoy, Keiningham e Oliver (2014), para quem há quatro itens fundamentais que definem esta dimensão: (1) percepção de relação especial; (2) tratamento favorável aos objetos de lealdade; (3) desejo de manter o relacionamento mesmo quando sacrifícios são necessários e (4) defesa e reforço do relacionamento. Com base nestes quatro pontos, então, os autores propõem a seguinte definição: "Lealdade é o reconhecimento do quão especial é um relacionamento, o que resulta em um tratamento diferenciado e mais favorável a esta relação, a criação de um vínculo como resultado desta relação e a defesa e reforço deste relacionamento" (Aksoy et al., 2014, p. 38).

Conforme destacado por Ravald e Grönroos (1996), um aumento na percepção de valor do consumidor pode impactar em sua intenção de estabelecer e manter um relacionamento de longo prazo com a empresa. Pesquisadores de diversos setores têm estudado esta relação entre valor percebido e lealdade (Grewal, Iyer, Krishnan \& Sharma, 2003; Velázquez, Saura \& Molina, 2011; Taylor \& Hunter, 2014; Chen, 2015).

De forma geral, o valor percebido é uma característica individual de cada consumidor, de acordo com o que ele entende por benefício em relação ao sacrifício necessário para a obtenção do bem ou serviço (Zeithaml, 1988). Linha de pesquisa defendida por alguns autores (Vargo \& Lusch, 2004; Payne, Storbacka \& Frow, 2008; Grönroos, 2011) apresenta a tese de que, em serviços, o cliente não é apenas ente receptivo do valor criado pela empresa, mas também colaborador e cocriador no processo de desenvolvimento, até mesmo pelas características inerentes ao serviço, como impossibilidade de estoque e inseparabilidade de produção e consumo.

Sem um conceito rigorosamente formatado sobre como deve ser a relação entre consumidor e fornecedor de serviço para que haja a cocriação de valor, Prahalad e Ramaswamy (2004b) desenvolveram modelo pautado no monitoramento (ora passivo, ora ativo) do fornecedor em relação a quatro pontos-chave, sempre focando na interação entre os entes: diálogo, acesso, risco-benefício e transparência. 
Com o objetivo de formular um modelo que suprisse as lacunas de como ocorre a cocriação de valor, Payne et al. (2008) levantaram achados por meio de pesquisa qualitativa e entrevistas com altos executivos de empresas de diversas áreas de serviços e identificaram quatro principais componentes fundamentais para a cocriação de valor: processos de criação de valor do consumidor, processos de criação de valor do fornecedor, encontros e fontes adicionais de conhecimento acerca da marca.

Grönroos (2011), por sua vez, estabeleceu modelo com maior foco no consumidor, destacando que, em serviço, o valor é concebido em uso; assim, entende-se que o consumidor é que deve ser visto como realmente o criador de valor, com a empresa assumindo o papel de facilitadora do processo. Grönroos (2011) aponta que sem uma interação direta entre os entes, há apenas a criação do valor (pelo usuário), não a cocriação, o que torna fundamental que os empregados da empresa entendam as necessidades e expectativas dos consumidores, resultando em interações proveitosas, com trocas de informações e geração de oportunidades, para ambos os lados.

Em estudo de 2014, Taylor e Hunter revisitaram pesquisa desenvolvida por eles anteriormente (Taylor \& Hunter, 2003), onde buscavam entender os papéis de valor percebido, satisfação, confiança e atitude em relação à marca para explicar lealdade na indústria de eCRM (eletronic customer relationship management). Nesse novo estudo, o objetivo foi apontar as evoluções ocorridas entre relações após introdução do conceito de cocriação de valor por Vargo e Lusch (2004) e Grönroos (2011) de que o valor é fundamentalmente derivado e determinado na interação - ou uso - e não criado unicamente pela empresa. As conclusões foram que a relação entre as dimensões não sofreu grandes alterações mesmo após novos conceitos e avanços na teoria do marketing de serviços acerca da criação de valor; com incorporação ativa do consumidor, a lealdade encontra-se relacionada à [cocriação de] valor, por meio da satisfação.

Embora a educação superior possa ser entendida como um serviço, muito se discute se o que é fornecido pela universidade pode ser encarado como uma prestação de serviço tradicional, já que, se por um lado cada ente possui seus deveres e obrigações após a contratação (Kanji \& Tambi, 1999), por outro, a obtenção da qualificação - item oferecido pela universidade - depende do envolvimento e conduta do aluno (Eagle \& Brennan, 
2007), além do fato de o fornecimento do serviço só ocorrer após avaliação prévia do provedor sobre as habilidades do receptor (Svensson \& Wood, 2007).

Assim, no caso da educação, não há como o papel de criação do valor para o cliente (estudante) ser exclusividade do provedor do serviço (universidade); ela deve ocorrer necessariamente de forma conjunta, cocriada.

Neste contexto, mantendo o foco no mercado de $\mathrm{EaD}$, nos mitos a respeito da qualidade do ensino a distância e na questão apresentada a respeito das taxas de evasão - e usando como base estudos desenvolvidos para o ensino presencial, que apontam a relação entre lealdade e menores taxas de evasão em conjunto com estudos de outras áreas, que apontam relações entre valor percebido e qualidade, satisfação, lealdade -, esta pesquisa busca responder:

\section{Quais os aspectos de cocriação de valor são determinantes para impactar a qualidade percebida, a satisfação e a lealdade na educação a distância?}

Apesar de o setor de serviços representar cada vez mais do Produto Interno Bruto (PIB) nas economias desenvolvidas e emergentes (Maglio, Vargo, Caswell \& Spohrer, 2009), em geral, poucos estudos acerca da cocriação de valor foram realizados. Galvagno e Dalli (2014) fizeram levantamento bibliográfico nas principais plataformas de busca de artigos acadêmicos (SSCI, Scopus, Ebsco e Google Scholar) com o objetivo de resumir e classificar estudos passados e presentes sobre cocriação. Neste levantamento, realizado em trabalhos desenvolvidos entre janeiro de 2000 e dezembro de 2012, obtiveram, em um primeiro momento, 2.568 itens, que após análise atenta se a presença dos trechos pesquisados (cocrea, co-crea, co crea) atendiam às definições de cocriação de valor, foram reduzidos para 711 referências, concentrados principalmente nos 2 últimos anos, indicando um crescente interesse por este tema, apesar do ainda baixo volume de publicações. Em educação, o tema da cocriação de valor foi pouco percorrido; em educação a distância, onde as interações entre os entes do processo se dão de forma diferenciada, nada (ou

pouco) presenciais, não foi possível obter, na literatura, pesquisa que elucidasse o problema levantado. 
Além de introduzir um tema pouco explorado - entender a cocriação de valor em EaD -, outra contribuição desta pesquisa é abordar este assunto relacionando-o à lealdade, à satisfação e à qualidade percebida, com a intenção de avaliar como ocorrem estas associações.

Portanto, a justificativa deste estudo tem como argumentos a originalidade - devido à escassez de publicações sobre cocriação de valor em educação - e a relevância decorrente da relação entre valor percebido (ou cocriado) e lealdade.

Estando abordada a justificativa, podem ser definidos os objetivos desta pesquisa.

\subsection{Objetivos da Pesquisa}

Esta pesquisa apresenta, como objetivo primário, avaliar os aspectos de ensino a distância que permitem a concretização da cocriação de valores, relacionando-os com qualidade percebida, satisfação e lealdade. Podem ser identificados como objetivos específicos:

a) Levantamento dos atributos relevantes à cocriação de valor em $\mathrm{EaD}$;

b) Identificação do impacto da cocriação de valor na qualidade percebida;

c) Identificação do impacto da cocriação de valor na satisfação;

d) Identificação do impacto da cocriação de valor na lealdade;

e) Análise da intensidade das relações entre dimensões considerando características dos estudantes e cursos frequentados por estes, como idade, localidade de moradia, área (exatas/humanas/biológicas) e tipologia dos cursos (licenciatura/bacharelado/ tecnólogo), entre outros. 


\subsection{Organização dos Capítulos}

O primeiro capítulo deste trabalho apresenta breve introdução ao tema proposto, pontuando principais questões abordadas ao longo do projeto, com justificativa sobre a escolha da pesquisa, além de apontar seus objetivos.

No segundo capítulo encontra-se o levantamento sobre conceitos e características da educação a distância ao longo do tempo e incorporação de dados que descrevem o perfil desta modalidade de ensino no Brasil.

A fundamentação teórica, que define cada ponto estudado, está contida no terceiro capítulo, segmentada segundo as seguintes seções:

- Serviços: revisão teórica sobre as abordagens de - e modelos desenvolvidos para - serviços, tratando-os de forma diferenciada em relação a bens de consumo (produtos);

- Valor e cocriação de valor: conceituação sobre valor e cocriação de valor, com levantamento sobre os modelos desenvolvidos por estudiosos do tema, para que seja possível sua adaptação à pesquisa;

- Satisfação e lealdade: breve levantamento teórico sobre as duas dimensões, focando especialmente o contexto da educação a distância;

- Qualidade percebida: breve descrição sobre dois dos principais modelos de qualidade em serviço;

- O ensino superior visto sob a perspectiva do serviço: integração do ensino superior aos conceitos de serviços e valoração.

O modelo de pesquisa com todas as relações consideradas - e respectivas hipóteses formuladas - para que fosse possível alcançar os objetivos do estudo, além da operacionalização das dimensões, está presente no capítulo quatro.

Em seguida, encontra-se o capítulo que especifica os aspectos metodológicos utilizados, detalhando a forma de amostragem, pesquisa e técnicas estatísticas utilizadas nas análises. 
As análises dos dados e as conclusões estão contempladas no sexto e no sétimo capítulos, respectivamente.

Por fim, encontram-se as referências bibliográficas e os apêndices. 


\section{EDUCAÇÃO A DISTÂNCIA}

Para contextualizar o estudo realizado, é importante entender o mercado a que ele se refere. Com este objetivo, esta seção busca conceituar a educação a distância (EaD), incorporando-a no contexto mundial e, especialmente, brasileiro, por meio de dados históricos e tendências deste modelo educacional.

Este capítulo aponta levantamento sobre o mercado de estudo - educação a distância - com informações relevantes acerca de seu contexto histórico recente e panorama da situação brasileira entre os anos 2000 e 2015.

\subsection{Conceitos e Características}

$\mathrm{O}$ primeiro conceito a ser discutido refere-se ao termo empregado neste trabalho. Com o passar do tempo, as definições essenciais sobre educação a distância sofreram algumas alterações ou complementações, tornando-se mais específicas.

Embora se possa supor que todo tipo de curso não presencial é, então, a distância, esta é uma visão simplista do termo, promovendo um "entendimento parcial do que é educação a distância e, em alguns casos, estabelece termos de comparação pouco científicos" com a modalidade presencial (Nunes, 1993).

Nos últimos anos da década de 1960 e durante a década de 1970, tinha-se bastante claro que o ensino a distância deveria englobar a separação entre alunos e professores, não importando o material utilizado para a transmissão do conhecimento. Porém, já neste período, entendia-se que a educação a distância devia possuir uma interação entre alunos e professores, impedindo, assim que um programa cultural na televisão, por exemplo, fosse considerado educação a distância. Um dos primeiros conceitos foi registrado por Dohmen (1967), para quem 
a educação a distância é uma forma de organização sistemática de auto-estudo no qual o aconselhamento aos estudantes, a apresentação do material e a garantia e supervisão do sucesso no aprendizado dos alunos são realizados por uma equipe de professores, cada um com responsabilidades. Torna-se possível por meio de uma mídia que cubra longas distâncias. O oposto de "educação a distância" é a "educação direta" ou "educação frente a frente": um tipo de educação que ocorre com o contato direto entre palestrantes e estudantes. (Dohmen, 1967, p. 9)

Com definição parecida, porém mais pragmática, em 1973, Peters define que

ensino/educação a distância é um método de transmissão de conhecimentos, habilidades e atitudes que é racionalizado pela aplicação de divisão de trabalho e princípios organizacionais, bem como pelo uso extensivo de mídias técnicas, especialmente com a finalidade de reproduzir material de ensino de alta qualidade, o que torna possível instruir um grande número de alunos ao mesmo tempo independente de onde eles morem. É uma forma industrializada de ensino e aprendizagem. (Peters, 1973, p. 206)

Focando muito mais no ferramental para a execução da educação a distância, Moore (1973) determina que

ensino a distância pode ser definido como a família de métodos de instrução nos quais os comportamentos de ensino são executados em separado dos comportamentos de aprendizagem [...] de modo que a comunicação [...] deva ser facilitada por dispositivos impressos, eletrônicos, mecânicos e outros. (Moore, 1973, p. 664)

Por fim, Holmberg, em 1977, reforça a necessidade de planejamento e organização no desenvolvimento de cursos da modalidade a distância

o termo "educação a distância" cobre várias formas de estudo, em todos os níveis, que não estão sob a supervisão contínua e imediata de tutores presentes com seus alunos em salas de aula ou nos mesmos lugares, mas que se beneficiam do planejamento, da orientação e do ensino oferecidos por uma organização tutorial. (Holmberg, 1977, p. 9)

Nas décadas seguintes, outros autores mantiveram a busca por maior detalhamento da definição de educação a distância, reforçando ao conceito até então traçado, principalmente, a necessidade de contínua interação entre professores e alunos e entre colegas de turma - até mesmo em encontros frente a frente pontuais, com propósitos tanto educacionais quanto sociais. Garrison e Shale (1987) conceituam que

educação a distância implica que a maioria da comunicação educacional entre professor(es) e aluno(s) ocorre de forma não presencial. Deve envolver a comunicação de duas vias entre professor(es) e aluno(s) com a finalidade de facilitar e apoiar o processo 
educacional. Ela usa a tecnologia para mediar a necessária comunicação bidirecional. (Garrison \& Shale, 1987, p. 11)

Com o advento das novas tecnologias das [tele]comunicações, que passam a permitir o emprego de áudio e/ou vídeo (em relação à correspondência), Barker, Friesbie e Patrick (1989) discutem a ampliação da definição de educação a distância com a possibilidade de trocas imediatas entre professores e alunos, aproximando a experiência obtida àquela da sala de aula tradicional.

Apesar de muitas vezes as expressões educação a distância e ensino a distância serem utilizadas como sinônimos, Preti (1996) reforça, parafraseando Maroto (1995), que, "Ensino representa instrução, socialização de informação, aprendizagem, etc.", enquanto Educação é "estratégia básica de formação humana, aprender a aprender, saber pensar, criar, inovar, construir conhecimento, participar, etc".

Acompanhando o que pregam os autores citados até então, Keegan (1996) ressalta que para haver educação a distância é necessário que haja tanto ensino a distância quanto aprendizado a distância, ou seja, que exista uma interação professor-estudante tornando possível a transmissão do conhecimento de forma clara - com materiais e tecnologias adequados - e a captação deste conhecimento pelo aluno.

Com foco no histórico da educação a distância, Keegan (1996) avalia, ainda, que a educação a distância tornou-se possível a partir do desenvolvimento de tecnologias de transporte e comunicação ocorridas no período da Revolução Industrial, entre os séculos XVIII e XIX, uma vez que "a educação a distância é caracterizada pela separação do professor e do aluno e do aluno e dos colegas, com a relação pessoal frente a frente da educação convencional sendo substituída por uma relação impessoal mediada pela tecnologia", que pode ser desde cartas até o uso de equipamentos considerados inovadores, como computadores, tablets e celulares.

Do início do século XX até a Segunda Guerra Mundial, foram adotadas diversas modalidades de comunicação para a realização de cursos a distância, acompanhando as inovações ocorridas em cada período, tendo sido o rádio uma importante ferramenta de difusão das aulas, em conjunto com as correspondências tradicionais. Durante a Segunda 
Guerra, o uso do telégrafo na capacitação dos recrutas norte-americanos por meio de código Morse mostrou-se bastante relevante.

A partir da década de 1950, se juntam às formas de ensino até então tradicionais, as novas tecnologias, como a televisão; no final do século XX, o computador - com a Internet - e, no século seguinte, o celular. A introdução da Internet permitiu que os alunos tivessem a oportunidade de interagir com professores e "colegas de turma" de forma dinâmica e individualizada, tornando a educação a distância mais próxima de uma relação pessoal (frente a frente), como ocorre com os cursos presenciais.

Focando especialmente no Brasil, muitos foram os programas de incentivo governamentais para a educação a distância ao longo do tempo - especialmente para a educação básica -, além da criação de empresas privadas voltadas a essa modalidade, como o Instituto RádioMonitor (1939) e o Instituto Universal Brasileiro (1941).

Dentre os programas para o desenvolvimento educacional da população, um programa que se destaca é o Movimento de Educação de Base (MEB), desenvolvido em 1961 pela Conferência Nacional dos Bispos do Brasil com o objetivo de alfabetizar e acompanhar a educação básica por meio de escolas radiofônicas, com especial atenção aos estados do Norte, Nordeste e Centro-Oeste (MEB, 2011).

O primeiro curso de graduação a distância no Brasil foi o de Pedagogia de $1^{\mathrm{a}}$ a $4^{\mathrm{a}}$ séries, criado em 1995 em caráter experimental para professores em serviço da rede pública estadual e municipal pela Universidade Federal do Mato Grosso (Moran, 2002). Até então, o foco era em cursos do tipo supletivo ou de alfabetização ou dados esporadicamente pela Universidade de Brasília no contexto de especialização. Foi apenas em 1996 que a Lei de Diretrizes e Bases (LDB) da Educação reconheceu a educação a distância, possibilitando a criação de cursos em diversos níveis e seu crescimento em importância com relação à totalidade de cursos oferecidos pelas escolas de ensino superior.

Em 2006, é instituído o Sistema UAB (Universidade Aberta do Brasil), programa do Ministério da Educação (MEC) que apresenta como principal objetivo a ampliação e interiorização da oferta de cursos e programas de educação superior, por meio da educação 
a distância, com prioridade à formação de professores e outros profissionais da educação básica da rede pública. Possui também a proposta de disseminação do ensino superior desenvolvendo um "amplo sistema nacional de educação superior a distância". Neste programa, são designados polos de ensino nos municípios permitindo o contato presencial esporádico dos estudantes, além do ensino a distância (Ministério da Educação, 2015).

\subsection{Números da Educação a Distância no Ensino Superior Brasileiro}

Apesar do reconhecimento da educação a distância pela LDB ter ocorrido em 1996, foi apenas em 2005 que esta modalidade de educação mostrou o primeiro grande crescimento para o ensino superior. Segundo dados dos censos escolares da educação superior, levantados pelo Instituto Nacional de Estudos e Pesquisas Educacionais Anísio Teixeira (INEP, 2016) e que podem ser observados na Tabela 1, em 2004 havia 58.611 alunos matriculados em cursos de graduação a distância. No ano seguinte, este número foi para 114.642, um aumento de $96 \%$.

Tabela 1

Número de cursos, vagas e matrículas: EaD e presencial, 2000 a 2015

\begin{tabular}{ccc|cc|cc}
\hline \multirow{2}{*}{ Ano } & \multicolumn{2}{c|}{ Cursos de Graduação } & \multicolumn{2}{c|}{ Vagas } & \multicolumn{2}{c}{ Matrículas } \\
\cline { 2 - 7 } & EaD & Presenciais & EaD & Presenciais & EaD & Presenciais \\
\hline 2000 & 10 & 10.585 & 6.430 & 1.216 .287 & 1.682 & 2.694 .245 \\
2001 & 8 & 12.155 & 6.856 & 1.408 .492 & 5.359 & 3.030 .754 \\
2002 & 46 & 14.399 & 24.389 & 1.773 .087 & 40.714 & 3.479 .913 \\
2003 & 52 & 16.453 & 24.025 & 2.002 .733 & 49.911 & 3.887 .022 \\
2004 & 107 & 18.644 & 113.079 & 2.320 .421 & 58.611 & 4.163 .733 \\
2005 & 189 & 20.407 & 423.411 & 2.435 .987 & 114.642 & 4.453 .156 \\
2006 & 349 & 22.101 & 780.777 & 2.629 .598 & 207.206 & 4.676 .646 \\
2007 & 408 & 23.488 & 1.541 .070 & 2.823 .942 & 369.766 & 4.880 .381 \\
2008 & 647 & 24.719 & 1.699 .489 & 2.985 .137 & 727.961 & 5.080 .056 \\
2009 & 844 & 27.827 & 1.561 .715 & 3.164 .679 & 838.125 & 5.115 .896 \\
2010 & 930 & 28.577 & 1.634 .118 & 3.120 .192 & 930.179 & 5.449 .120 \\
2011 & 1.044 & 29.376 & 1.224 .760 & 3.228 .671 & 992.927 & 5.746 .762 \\
2012 & 1.148 & 30.718 & 1.329 .407 & 3.324 .407 & 1.113 .850 & 5.923 .838 \\
2013 & 1.258 & 30.791 & 1.638 .427 & 3.429 .715 & 1.153 .572 & 6.152 .405 \\
2014 & 1.365 & 31.513 & 2.800 .358 & 3.545 .294 & 1.341 .842 & 6.486 .171 \\
2015 & 1.473 & 32.028 & 2.387 .865 & 3.754 .284 & 1.393 .752 & 6.633 .545 \\
\hline Nota. Compilado pela autora com base nos censos escolares da educação superior (INEP, 2016).
\end{tabular}

Nota. Compilado pela autora com base nos censos escolares da educação superior (INEP, 2016). 
Por meio da Tabela 1, é possível avaliar o número de cursos de graduação de forma comparativa entre o ensino a distância e o presencial, de 2000 até 2015: o primeiro tipo possuía, em 2000, apenas 10 cursos frente a 10.585 cursos da modalidade tradicional, ou seja, os cursos a distância representavam apenas $0,1 \%$ do total de 10.595 cursos de graduação. Já em 2005, com 189 cursos EaD e 20.407 presenciais, os cursos a distância já significavam $0,9 \%$ do total de cursos de graduação disponíveis no país. Com aumento relevante entre 2005 e 2015, a representatividade dos cursos $\mathrm{EaD}$ passou a ser de 4,4\% em 2015 (1.473 cursos a distância dentre os 33.501 cursos de graduação como um todo), crescimento de $389 \%$ na participação em relação a 2005.

Com propostas diferenciadas em relação ao alcance, o número de vagas por curso na modalidade a distância é bastante superior ao da modalidade presencial: com apenas 10 cursos disponíveis em 2000, já eram 6.430 as vagas disponíveis (média de 643 vagas por curso); 10 anos mais tarde, o número médio de vagas por curso era de 1.757 (1.634.118 vagas para 930 cursos). Comparativamente, nos mesmos anos, os cursos presenciais tinham média de 115 vagas por curso em 2000 e 109 em 2010 (Tabela 1). Conforme aponta Oliveira (2009), a criação do programa UAB e as políticas governamentais ocorridas no segundo mandato do Governo Lula durante os anos de 2005 e 2008, resultaram em forte aumento da oferta de cursos de graduação a distância, com diminuição no ritmo nos anos seguintes, em linha com o que se observa pelo censo escolar da educação superior levantado pelo INEP.

Uma vez que o estudante do ensino a distância não possui o compromisso de frequência ao polo como aquele aluno do formato tradicional de ensino, podia-se supor que o número de concluintes em relação aos matriculados fosse mais baixo na modalidade $\mathrm{EaD}$. Isto de fato parece ocorrer até 2009; porém, os dados indicam que a partir deste ano e até 2011, os dois métodos educacionais possuem patamares equivalentes, em torno de 15 a 16 concluintes para cada 100 matriculados, conforme Tabela 2. A partir de 2013, é possível notar uma queda no total de concluintes em relação às matrículas para ambas as modalidades, sendo mais acentuada para a presencial, reflexo, especialmente, da retração da economia e mudança de regras de incentivos creditícios específicos, como FIES (Folha de São Paulo, 
2015; Correio Braziliense, 2016). Importante ressaltar que a graduação em EaD não faz parte dos cursos atendidos pelo FIES.

Tabela 2

Número de matrículas e concluintes: EaD e presencial, 2000 a 2015

\begin{tabular}{|c|c|c|c|c|c|c|}
\hline \multirow[t]{2}{*}{ Ano } & \multicolumn{2}{|c|}{ Matrículas } & \multicolumn{2}{|c|}{ Concluintes } & \multicolumn{2}{|c|}{$\begin{array}{l}\text { Total de concluintes para } \\
\text { cada } 100 \text { matrículas }\end{array}$} \\
\hline & $\mathrm{EaD}$ & Presenciais & $\mathrm{EaD}$ & Presenciais & $\mathrm{EaD}$ & Presenciais \\
\hline 2000 & 1.682 & 2.694 .245 & 460 & 324.734 & 27,3 & 12,1 \\
\hline 2001 & 5.359 & 3.030 .754 & 131 & 352.305 & 2,4 & 11,6 \\
\hline 2002 & 40.714 & 3.479 .913 & 1.712 & 466.260 & 4,2 & 13,4 \\
\hline 2003 & 49.911 & 3.887 .022 & 4.005 & 528.223 & 8,0 & 13,6 \\
\hline 2004 & 58.611 & 4.163 .733 & 6.746 & 626.617 & 11,5 & 15,0 \\
\hline 2005 & 114.642 & 4.453 .156 & 12.626 & 717.858 & 11,0 & 16,1 \\
\hline 2006 & 207.206 & 4.676 .646 & 25.804 & 736.829 & 12,5 & 15,8 \\
\hline 2007 & 369.766 & 4.880 .381 & 29.812 & 756.799 & 8,1 & 15,5 \\
\hline 2008 & 727.961 & 5.080 .056 & 70.068 & 800.318 & 9,6 & 15,8 \\
\hline 2009 & 838.125 & 5.115 .896 & 132.269 & 826.928 & 15,8 & 16,2 \\
\hline 2010 & 930.179 & 5.449 .120 & 144.553 & 829.286 & 15,5 & 15,2 \\
\hline 2011 & 992.927 & 5.746 .762 & 151.552 & 865.161 & 15,3 & 15,1 \\
\hline 2012 & 1.113 .850 & 5.923 .838 & 174.322 & 876.091 & 15,7 & 14,8 \\
\hline 2013 & 1.153 .572 & 6.152 .405 & 161.072 & 829.938 & 14,0 & 13,5 \\
\hline 2014 & 1.341 .842 & 6.486 .171 & 189.788 & 837.304 & 14,1 & 12,9 \\
\hline 2015 & 1.393 .752 & 6.633 .545 & 233.704 & 916.363 & 16,8 & 13,8 \\
\hline
\end{tabular}

Nota. Compilado pela autora com base nos censos escolares da educação superior (INEP, 2016).

Com base na Tabela 3, nota-se que as escolas particulares passaram a demonstrar interesse mais intenso sobre os cursos a distância a partir de 2004; até 2001 (inclusive), todos os cursos EaD dados no Brasil eram oferecidos por escolas públicas. Em 2004, 65,4\% dos cursos desta modalidade eram realizados por escolas particulares, índice bastante similar àquele observado na modalidade presencial $(66,4 \%)$. $O$ percentual sofreu uma queda a partir de 2009 e nova tendência de elevação desde 2010. No último dado disponível (2015), as escolas públicas eram responsáveis por 28,6\% dos cursos EaD e 32,3\% dos cursos presenciais. 
Tabela 3

Percentual de cursos de graduação oferecidos por escolas particulares: EaD e presencial, 2000 a 2015

\begin{tabular}{ccc}
\hline \multirow{2}{*}{ Ano } & \multicolumn{2}{c}{ Cursos em escolas particulares } \\
\cline { 2 - 3 } & EaD & Presenciais \\
\hline 2000 & $0,0 \%$ & $62,0 \%$ \\
2001 & $0,0 \%$ & $63,8 \%$ \\
2002 & $19,6 \%$ & $63,5 \%$ \\
2003 & $30,8 \%$ & $65,6 \%$ \\
2004 & $65,4 \%$ & $66,4 \%$ \\
2005 & $65,1 \%$ & $69,7 \%$ \\
2006 & $68,8 \%$ & $70,4 \%$ \\
2007 & $68,4 \%$ & $71,9 \%$ \\
2008 & NI & $72,6 \%$ \\
2009 & $37,1 \%$ & $70,4 \%$ \\
2010 & $54,4 \%$ & $69,1 \%$ \\
2011 & $55,5 \%$ & $68,1 \%$ \\
2012 & $55,5 \%$ & $66,2 \%$ \\
2013 & $59,8 \%$ & $66,4 \%$ \\
2014 & $68,7 \%$ & $66,3 \%$ \\
2015 & $71,4 \%$ & $67,7 \%$ \\
\hline
\end{tabular}

Notas. NI = não informado. Compilado pela autora com base nos censos escolares da educação superior (INEP, 2016).

Na próxima seção será discutido o perfil do estudante de graduação brasileiro com base nos dados do último censo da educação superior (INEP, 2016), comparando os alunos da modalidade presencial e aqueles do $\mathrm{EaD}$. 


\subsection{Educação a Distância no Ensino Superior: Perfil do Aluno Brasileiro}

A partir dos microdados do censo escolar da educação superior (INEP, 2016), podem-se obter as informações do perfil do estudante de graduação brasileiro em 2015. A Figura 1 representa a distribuição dos alunos conforme região e localidade. Com relação à região de moradia, nota-se que a maior concentração ocorre nos estados do Sudeste, onde $45 \%$ dos estudantes do ensino presencial residem e $41 \%$ daqueles dos cursos a distância. As regiões Norte e Sul apresentam maior proporção de alunos de $\mathrm{EaD}$ do que ensino presencial, refletindo, no primeiro caso, a dificuldade de acesso aos cursos tradicionais por falta de vagas nas regiões menos populosas do país e, consequentemente, maior procura pelos cursos a distância e ações de expansão de faculdades relevantes em números de alunos, com investimentos privilegiando a modalidade $\mathrm{EaD}$ (Koike, 2015). Uma avaliação comparativa entre capital dos estados e interior, mostra a grande presença do interior nos cursos $\mathrm{EaD}$, locais onde também há menos escolas que atuam na modalidade presencial.

$\mathrm{EaD}$

Distribuição dos alunos por região do Brasil

Distribuição dos alunos segundo localidade
Presencial
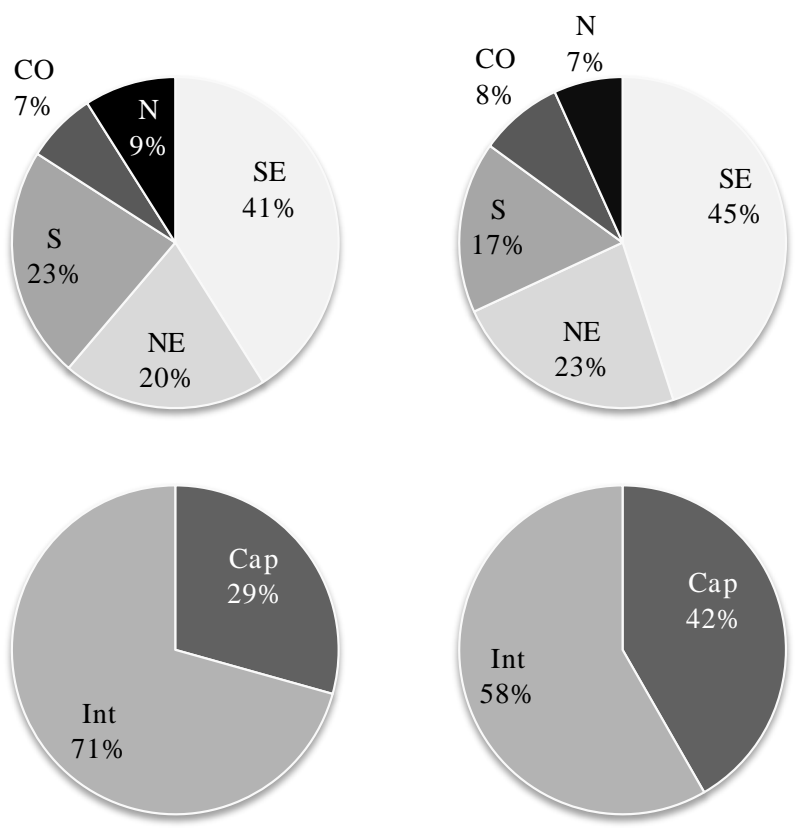

Figura 1. Distribuição dos alunos por regiões e localidade: EaD e presencial, 2015. SE: Sudeste; NE: Nordeste; S: Sul; CO: Centro-Oeste; N: Norte. Cap: Capital; Int: Interior. Compilado pela autora com base nos censos escolares da educação superior (INEP, 2016). 
Com relação ao gênero, sendo 50,5\% dos residentes no país entre 17 e 64 anos, segundo projeção da população realizada pelo Instituto Brasileiro de Geografia e Estatística (IBGE, 2013), as mulheres se sobressaem em ambas as modalidades de cursos. A maior procura pelo ensino superior por elas é objeto de pesquisa desde a década de 1970. Barroso e Mello (1975) analisaram a evolução das escolhas das mulheres e desempenho no vestibular; Rosemberg e Amado (1992), ao discutirem a questão de gêneros no sistema educacional brasileiro, levantam a diferença no significado de frequentar a escola para ambos os sexos e a gradativa desvinculação entre trabalho e escola, com os homens tendo que assumir o papel de provedor do lar mais cedo em uma sociedade patriarcal e, assim, deixando os estudos mais cedo comparativamente às mulheres.

$\mathrm{Na}$ análise comparativa entre modalidades, representada pela Figura 2, nota-se que as mulheres são ainda mais frequentes nos cursos EaD. Uma explicação para tal situação pode ser o alto volume de cursos do tipo licenciatura, especialmente em profissões voltadas ao ensino básico, que, como já visto na Seção 2.1, foi a prioridade na criação dos cursos EaD. Quando considerada apenas a licenciatura, as mulheres representam 77,2\% dos estudantes de cursos a distância e $65,4 \%$ dos cursos presenciais.

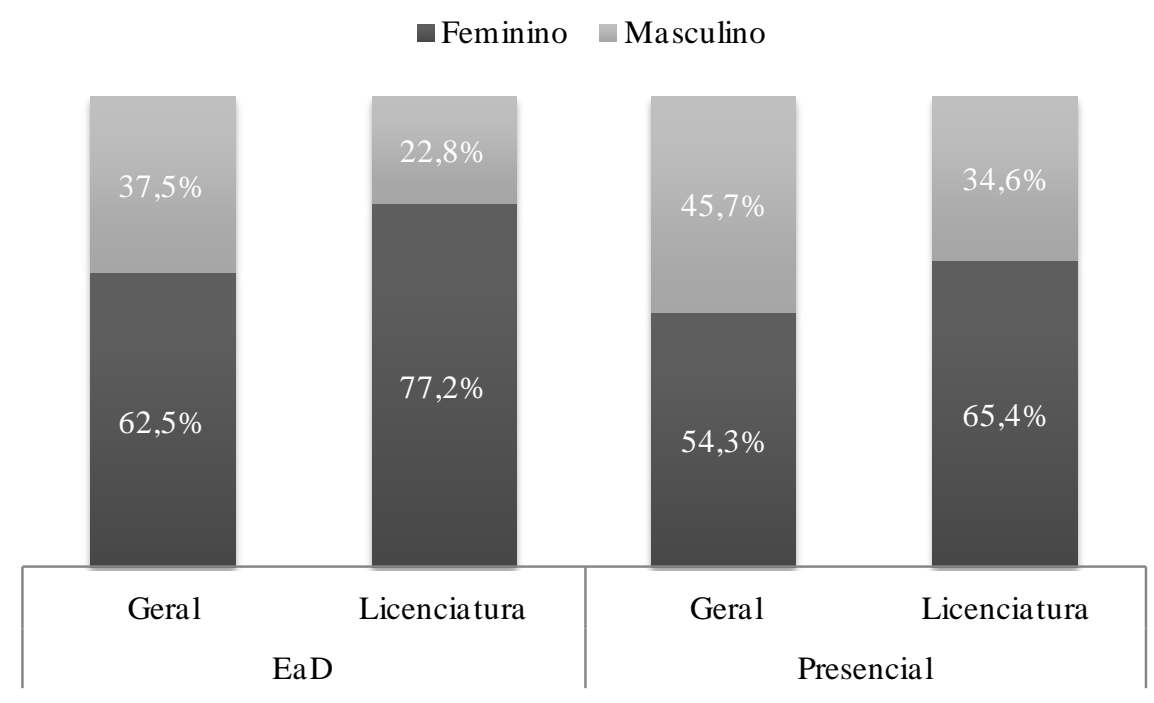

Figura 2. Distribuição dos alunos por gênero: $\mathrm{EaD}$ e presencial, cursos em geral e licenciatura, 2015. Compilado pela autora com base nos censos escolares da educação superior (INEP, 2016). 
Observando a faixa etária, percebe-se distribuição bastante diferente entre as modalidades: enquanto que nos cursos presenciais 54,3\% dos estudantes têm idade entre 17 e 24 anos, nos cursos EaD, esta faixa etária responde por $20,4 \%$ do total de alunos. Uma análise entre os mais velhos, a partir de 35 anos, indica que apenas 13,3\% dos alunos de cursos tradicionais estão nesta faixa etária - percentual $65 \%$ menor do que percentual referente aos estudantes de cursos a distância, que é de 37,6\% (Tabela 4).

Tabela 4

Distribuição de alunos por faixa etária: EaD e presencial, 2015

\begin{tabular}{lcc}
\hline \multirow{2}{*}{ Faixa Etária } & \multicolumn{2}{c}{ Alunos nos cursos } \\
\cline { 2 - 3 } & EaD & Presenciais \\
\hline Até 16 anos & $0,0 \%$ & $0,0 \%$ \\
17 a 24 anos & $20,4 \%$ & $54,3 \%$ \\
25 a 29 anos & $21,0 \%$ & $21,2 \%$ \\
30 a 34 anos & $21,0 \%$ & $11,3 \%$ \\
35 a 39 anos & $16,1 \%$ & $6,3 \%$ \\
40 a 49 anos & $16,0 \%$ & $5,2 \%$ \\
A partir de 50 anos & $5,5 \%$ & $1,8 \%$ \\
\hline
\end{tabular}

Nota. Compilado pela autora com base nos censos escolares da educação superior (INEP, 2016).

Por fim, destaca-se o nível de desistência de matrícula: com maior flexibilidade nos horários de estudos e necessidade de disciplina para acompanhar o curso mesmo de longe, o percentual de estudantes que trancaram ou cancelaram a matrícula em 2015 em relação ao número de alunos que estavam cursando ou se formaram naquele ano era $45 \%$ maior na modalidade $\mathrm{EaD}$ em relação à modalidade presencial $(50,1 \%$ contra $35,1 \%)$, conforme Tabela 5.

Tabela 5

Número de alunos segundo situação de matrícula: EaD e presencial, 2015

\begin{tabular}{lcc}
\hline \multirow{2}{*}{ Situação } & \multicolumn{2}{c}{ Alunos nos cursos } \\
\cline { 2 - 3 } & EaD & Presenciais \\
\hline Cursando ou formados & $1.393 .752(66 \%)$ & $6.633 .545(74 \%)$ \\
Matrícula cancelada ou trancada & $708.713(34 \%)$ & $2.327 .243(26 \%)$ \\
\hline
\end{tabular}

Nota. Compilado pela autora com base nos censos escolares da educação superior (INEP, 2016). 
Uma vez apresentados os conceitos de educação a distância, sua evolução e perfil do aluno no contexto brasileiro, pode-se iniciar a fundamentação teórica para obtenção de modelo que suporte o alcance dos objetivos deste estudo. 


\section{FUNDAMENTAÇÃO TEÓRICA}

Este capítulo está dividido em cinco seções e traz um levantamento bibliográfico sobre o tema principal deste trabalho, com o foco de embasamento do projeto, apontando o conjunto de estudos sobre a temática do problema de pesquisa.

\subsection{Serviços}

Com os primeiros estudos relativos ao Marketing baseados em fundamentações dos modelos de troca até então estudados pela Economia, focados nas distribuições e trocas de commodities e "bens", em geral fabricados (Shaw, 1912; Smith, 1998; Marshall, 2014), a literatura traz de forma bastante objetiva uma definição sobre produtos, tornando-os equivalentes a bens manufaturados, com a característica de serem tangíveis e cuja perecibilidade ao uso possibilite a classificação entre duráveis ou não duráveis. $\mathrm{O}$ mesmo não pode ser dito sobre serviços, onde as definições, mesmo sofrendo alterações ao longo do tempo, não são claras e tampouco apresentam características próprias. Elas se apresentam, em geral, como uma negação de algo (produto) ou parte agregada ao produto.

Autores como Judd (1964) e Rathmell (1966) definem serviços como tudo o que não é produto e eles próprios levantam que esta definição não é capaz de absorver as características do serviço. Já Solomon, Surprenant, Czepiel e Gutman (1985) e Lovelock (1991) focam a definição de serviços na questão da intangibilidade, sendo, portanto, um serviço tudo aquilo que não é um objeto ou um bem tangível; é um processo, não um bem.

Seguindo a linha da descrição do serviço como sendo algo que não é um produto, uma das definições mais difundidas na literatura foi desenvolvida por Zeithaml, Parasuraman e Berry (1985) e é baseada em quatro características opostas ao que se encontra em produtos: intangibilidade (impossibilidade do toque), heterogeneidade (incapacidade de padronização, por falta de homogeneidade), inseparabilidade de produção e consumo 
(impossibilidade de compra para uso futuro; produção e consumo ocorrem simultaneamente) e perecibilidade (impossibilidade de manutenção de estoque de serviços).

A importância do setor de serviços no Produto Interno Bruto apresenta, desde a década de 1950, crescimento frente aos setores agrícola e industrial. Nos países desenvolvidos no início do século XXI, esse setor representa entre $70 \%$ e $80 \%$ do PIB e empregos, enquanto que os setores agrícola e industrial respondem, respectivamente, por $5 \%$ e $15 \%$ a $25 \%$ (Tien \& Berg, 2006). Mesmo em países como Índia e China, o crescimento foi vertiginoso nos primeiros anos do século, em função de políticas de estímulo da área de tecnologia no primeiro caso e meta de modernização do setor no segundo (Maglio et al., 2009). Segundo dados oficiais divulgados pelo Instituto Brasileiro de Geografia e Estatística (IBGE, 2016), o setor de Serviços representou, em 2014, 62,4\% do PIB brasileiro, maior participação desde 1996.

Com o passar das décadas, novas perspectivas foram emergindo com uma lógica revisada, focada em recursos intangíveis, cocriação de valor e relações. Segundo Vargo e Lusch (2004), as novas perspectivas estão convergindo para formar uma nova lógica dominante de Marketing; uma na qual prestação de serviços - e não bens - é fundamental para a troca econômica.

Para Vargo e Lusch (2004), a separação entre produtos e serviços é ultrapassada, uma vez que, do ponto de vista do consumidor, tudo o que ele possui the rende um serviço e lhe satisfaz no uso, seja objeto, seja uma atividade. Assim, definem serviço como sendo "a aplicação de competências especializadas (conhecimentos e habilidades) por meio de atos, processos e performances para o benefício de outra entidade ou a própria entidade”. Logo, a lógica dominante centrada em serviço representa a filosofia reorientada que é aplicada a todas as ofertas de comercialização, incluindo aquelas que envolvem bens tangíveis no processo de prestação de serviço.

Mais ampla do que uma visão orientada para o consumidor, a visão centrada em serviço é centrada no consumidor (Sheth, Sisodia \& Sharma, 2000) e direcionada pelo mercado (Day, 1999), implicando um processo de criação de valor em conjunto com o cliente, que 
passa a ter um papel de colaborador - e cocriador de valor em todas as etapas do processo, de forma a suprir suas necessidades e expectativas - e não apenas receptor do produto final. Haeckel (1999) observa que as empresas de sucesso saíram da estratégia "fazer e vender" para a estratégia "sentir e responder".

\subsubsection{S-D logic approach}

A abordagem da lógica do serviço dominante (S[ervice]-D[ominant] logic approach) foi inicialmente proposta por Vargo e Lusch (2004) e posteriormente refinada pelos próprios autores em 2008 (Vargo \& Lusch, 2008). Esta abordagem se contrapõe à tradicional (chamada pelos autores de G[oods]-D[omintant] logic approach), que é focada em trocas no contexto de bens manufaturados e apresenta, como ponto principal, a ideia de que serviço - entendido como aplicação de competências e conhecimentos em benefício de outros - é a base fundamental da criação de valor por meio de trocas, havendo sempre a troca de serviço por serviço, tanto direta (ocorrida em trocas de serviços entre entes) quanto indiretamente (ocorrida em trocas por bens, que sintetizam competências que atendam às necessidades de outros em elemento tangível).

Enquanto que a abordagem $G$-D logic, também chamada de Neoclassical economics research tradition por Hunt (2000), Manufacturing logic por Normann (2001) e Old enterprise logic por Zuboff e Maxmin (2002), assume os serviços (importante destaque para a palavra no plural) como sendo um bem entregável - apesar de intangível -, muitas vezes agregado ao produto e, portanto, inferior em importância, a abordagem $S$-D logic enxerga o serviço (aqui no singular, para identificar o processo) como o processo de fazer algo para e com alguém, com a criação do valor saindo da responsabilidade exclusiva do prestador do serviço para uma relação colaborativa. Nesta abordagem, o valor é sempre cocriado.

Neste contexto, Vargo e Lusch $(2004,2006,2008)$ definem 10 premissas fundamentais da S-D logic approach. 
Premissa 1: Serviço é a base fundamental de troca

Os autores apontam que as pessoas possuem habilidades físicas e mentais, com distribuição heterogênea pela população e apenas as suas próprias habilidades não são suficientes para a sua sobrevivência ou bem-estar. Assim, parece razoável que os indivíduos busquem suprir as suas necessidades por meios que contemplem a troca de suas competências por competências de outros. Uma vez que a definição de serviço pela abordagem $S$-D logic é justamente a aplicação de conhecimentos e habilidades para benefício de outros, a primeira premissa reforça que as trocas para andamento do sistema são feitas entre serviços. Ele é visto como peça fundamental no processo.

É importante destacar que, em seu artigo de 2004, onde a abordagem foi originalmente proposta, Vargo e Lusch definiam essa primeira premissa como sendo "A aplicação de conhecimentos e habilidades especializadas é a unidade fundamental de troca", reforçando que, dado que a melhor moeda de troca entre indivíduos é justamente seu conhecimento, especializar-se torna os processos mais eficientes para todos os entes envolvidos. A alteração se deu em função de levantamentos de outros acadêmicos acerca dos termos usados, como Ballantyne e Varey (2006) sugerindo que o termo "unidade fundamental de troca" contradizia o que era defendido pela teoria da abordagem, além da busca pela simplificação de forma a refletir mais diretamente o papel central do serviço nas trocas.

Premissa 2: Trocas indiretas mascaram a base fundamental de troca

Ao longo do tempo, as trocas de habilidades especializadas indivíduo a indivíduo foram substituídas por empresas com diversos níveis hierárquicos, fazendo com que o consumidor se tornasse distante daquele que oferece a competência. Os autores, porém, defendem que, mesmo com as trocas de habilidades (serviço na definição da abordagem) ocorrendo por meio de produto, dinheiro e empresas, elas ainda são a base fundamental da troca. O processo fundamental não mudou e as pessoas ainda coletam e oferecem, fundamentalmente, habilidades especializadas de e para outras pessoas em sistemas monetarizados. Ele foi apenas mascarado pelos veículos de troca (dinheiro, produtos e empresas). 
Premissa 3: Bens são mecanismos de distribuição para a prestação de serviços

Segundo Normann e Ramirez (2005), bens tangíveis podem ser vistos como conhecimento ou atividades encapsulados. É com este contexto que Vargo e Lusch (2004) defendem a premissa 3, sugerindo que os bens nada mais são do que uma forma de entrega das habilidades individuais, transmitidas indiretamente, ao invés de diretamente ou por meio de educação e treinamento.

No caso de bens tangíveis, o consumidor, ao receber o produto, ainda participa de sua criação de valor, uma vez que deve aprender a lidar com o bem de modo a usar o objeto da melhor forma possível, extraindo, então, o conhecimento ali colocado pelo outro ente (empresa) do processo de troca.

Premissa 4: Recursos operantes são a fonte fundamental da vantagem competitiva

Em sua proposta de abordagem, Vargo e Lusch (2004) definem recursos operantes como sendo recursos dinâmicos, intangíveis, capazes de gerar valor, como conhecimento e habilidade, em contraponto aos recursos operandos, que são aqueles estáticos, em geral tangíveis, que necessitam de uma ação para ter algum valor (Silva, 2014).

Segundo Mokyr (2002), o conhecimento possui uma parte prescritiva que pode ser entendida como tecnologia. São justamente essas tecnologias que Vargo e Lusch (2004) defendem como sendo o instrumento que os envolvidos no processo de troca (empresas e organizações) usam para ganhar vantagem competitiva sobre outras entidades.

Já para Ballantyne e Varey (2006), esta premissa deveria especificar que a renovação do conhecimento é a fonte fundamental da vantagem competitiva. Vargo e Lusch (2008), porém, entendem que esta especificidade está contemplada nos recursos operantes (intangíveis). 
Premissa 5: Todas as economias são economias de serviço

Apesar de a ciência econômica ser vista como defendida por Smith (1998), onde a riqueza da sociedade é criada pela aquisição de matéria tangível e, portanto, apenas bens tangíveis poderiam ter valor e serem considerados em trocas do ponto de vista tradicional, conforme premissa 2, Vargo e Lusch (2004) defendem que os bens tangíveis são meios de distribuição do serviço - conhecimento e habilidades específicos. Logo, o serviço caracteriza a essência das atividades econômicas.

Premissa 6: O consumidor é sempre um cocriador de valor

$\mathrm{Na}$ abordagem proposta, o consumidor deve ser sempre envolvido em todas as etapas do processo de criação de valor, de forma colaborativa e não apenas receptor do resultado final, criado pela empresa sem envolvimento do cliente. Os autores defendem que mesmo quando há a produção de um bem tangível, o consumidor participa da criação do valor, ainda que seja envolvido no processo apenas no recebimento do produto - e, portanto, não pode ser considerado coprodutor -, conforme destacado na premissa 3. Em serviço, a coprodução e a cocriação se confundem, uma vez que não há prestação de serviço sem consumidor, requerendo, portanto, interação entre entes.

\section{Premissa 7: A empresa não pode entregar valor, só pode oferecer propostas de valor}

A empresa sozinha consegue apenas entregar propostas de valor, uma vez que é papel do consumidor determinar o valor e participar de sua criação por meio de processo de coprodução e valor em uso. Conforme destacado por Gummesson (1998, p. 247), "se o consumidor é o ponto focal do marketing, a criação de valor só é possível quando um bem ou serviço é consumido. Um bem não vendido não tem valor e um serviço prestado sem um consumidor não produz nada". 
Premissa 8: Uma visão centrada no serviço é inerentemente orientada para o cliente e relacional

Conforme já destacado nas premissas anteriores, a abordagem proposta espera interatividade, integração, customização e coprodução entre os entes envolvidos na troca. Esta visão de que as empresas não apenas produzem algo para o consumidor e sim com o consumidor, que deve estar sempre envolvido no processo, está inerentemente presente no modelo centrado em serviço.

Premissa 9: Todos os atores sociais e econômicos são integradores de recursos

Premissa presente originalmente em artigo escrito por Vargo e Lusch (2006), este ponto resume a importância de todos os entes (atores, agentes) envolvidos no processo de troca. É destaque de Spohrer, Maglio, Bailey e Gruhl (2007) quando definem os sistemas de serviço.

De forma geral, para que haja a troca de habilidades e conhecimentos que são pontos fundamentais da abordagem $S-D$ logic, há a necessidade de ao menos 2 entes: o que oferece o recurso e o beneficiário. A essa interação, Spohrer et al. (2007) deram o nome de sistemas de serviço, definindo-o como uma configuração de cocriação de valor dinâmica, que inclui pessoas, organizações, informações compartilhadas e tecnologia, tudo conectado interna e externamente a outro sistema de serviço por proposições de valor. No limite, todas as interações entre entes fazem parte do sistema de serviço.

Premissa 10: Valor é sempre único e fenomenalmente determinado pelo beneficiário Reforçando pontos já mencionados, o valor sempre é determinado pelo beneficiário. Aquele que o oferece, apresenta apenas uma proposta de valor. Sendo assim, como cada indivíduo é único, o valor passa a depender exclusivamente de suas experiências, contexto em que vive e características individuais, particulares. 


\subsubsection{Service logic approach}

Também direcionado ao ponto de vista dos serviços e ao papel do consumidor não apenas como ente receptivo, mas também colaborador e cocriador (ou criador) no processo de desenvolvimento de valor, Grönroos (2011) propôs a abordagem de lógica de serviço (S[ervice] logic approach). Ao apontar a importância de Vargo e Lusch (2004) ao trazerem à tona a discussão acerca da importância de serviço e sua diferenciação perante produto, além do levantamento realizado pelos autores sobre a história dos serviços, Grönroos e Gummerus (2014) destacam que, apesar de haver algumas similaridades entre a abordagem da lógica do serviço dominante ( $S$-D logic approach) e a abordagem da lógica de serviço (S logic approach), elas também se contradizem em diversos pontos.

As principais semelhanças entre ambas as abordagens dizem respeito à definição de serviço e sua relevância na sociedade, à importância da atuação do consumidor (ou qualquer usuário beneficiado pelo serviço) para a criação de valor, aplicando seus recursos físicos e mentais para que esta criação ocorra e à questão de que todo o tipo de troca envolve serviço, sendo, portanto, o bem manufaturado um meio para a entrega do que se oferece.

Já as diferenças se concentram, especialmente, no que tange os conceitos de criação de valor e fundamentos básicos das abordagens. Na abordagem $S$ logic, Grönroos e Gummerus (2014) defendem que não é o serviço e sim a criação de valor por todos os elementos envolvidos a base fundamental de troca; assim, além do serviço, fazem parte preço, custos e outros sacrifícios que também influenciam na criação de valor. Para os autores, o serviço é um facilitador; a criação de valor representa a base do negócio.

Outro ponto divergente diz respeito a quem cria o valor. Grönroos e Gummerus (2014) não concordam que o usuário e o prestador de serviço sejam sempre cocriadores de valor. Mais do que isso, sugerem que a criação - e a cocriação - de valor da forma como são definidas na abordagem $S-D$ logic são muito abrangentes, podendo ser interpretadas de formas diferenciadas dependendo do contexto, pois não estão muito claros os momentos em que a interação entre os agentes deve ocorrer para a criação de valor. 
Grönroos e Gummerus (2014) defendem que, uma vez que sem o uso do consumidor, não há prestação de serviço, o valor deve ser sempre interpretado como valor em uso, o qual ocorre durante o uso e, portanto, é criado pelo cliente nesse momento. Na visão destes autores, a empresa pode cocriar valor com o consumidor e não o contrário.

\subsubsection{Outras abordagens}

Saarijärvi, Kannan e Kuusela (2013) apresentam algumas outras abordagens com destaque para a cocriação de valor em serviços. Duas delas estão brevemente explicitadas a seguir.

Na abordagem many-to-many marketing, proposta por Gummesson (2007), há a discussão sobre o papel da rede do consumidor e o reforço sobre a importância de todos os agentes, sejam eles intermediários, empregados, vizinhos ou sociedade em geral, na cocriação de valor.

$\mathrm{Na}$ abordagem social constructionist approach introduzida por Edvardsson, Tronvoll e Gruber (2011), afirma-se que a cocriação de valor deve ser entendida levando em conta o contexto social, uma vez que cada ente envolvido no processo sofre influência de estruturas sociais, expressas por normas, valores e padrões éticos que guiam o que é - e não é - aceitável durante as interações. Neste contexto, a "cocriação de valor é moldada por forças sociais, reproduzida em estruturas sociais e pode ser assimétrica para os envolvidos" (Edvardsson et al., 2011, p. 327).

Embora divergentes na conceituação de alguns quesitos, todas as abordagens destacam a importância do serviço e o enfoque que deve ser dado a ele não como um complemento do produto, mas sim como material produzido com o objetivo de suprir necessidades dos consumidores. Mais do que isto, todas as abordagens enfatizam que o consumidor moderno deve deixar de ser visto pelas empresas atuando como um ente passivo, que consome o material apenas ao final e deve ser considerado como um colaborador e, principalmente, um [co]criador de valor, apontando suas necessidades e expectativas ao longo de todo o processo de desenvolvimento e momentos de uso. Considerações acerca de valor e cocriação de valor serão abordadas na próxima seção. 


\subsection{Valor e Cocriação de Valor}

Diferentemente do preço imposto, o valor de determinado produto ou serviço depende da percepção do consumidor, que será maior quanto maior for a diferença entre os benefícios entendidos pelo cliente e o custo efetivo da disponibilidade, aquisição ou uso do produto ou serviço. Com o intuito de aumentar o valor do que oferecem - e com isso apresentar vantagens competitivas em relação aos concorrentes e/ou aumentar o lucro -, as empresas passaram a perceber o consumidor não apenas receptor do que elas desenvolvem, mas também um ente participativo nesta concepção, cocriando o valor junto com a companhia. É neste contexto que esta seção se insere, trazendo conceitos de valor, especialmente focados em serviços, e como se dá a participação do cliente/consumidor no processo de cocriação do valor.

A definição de valor, seu entendimento e formas de aumentá-lo vêm sendo motivos de estudo por diversos autores (Ravald \& Grönroos, 1996; Sirdeshmukh, Singh \& Sabol, 2002; Chan, Yim \& Lam, 2010; Payne \& Frow, 2014; Sparks, Moutinho \& Grönroos, 2015). De maneira geral, o valor percebido de um produto ou serviço é uma característica individual de cada consumidor, uma vez que depende do quanto cada um está disposto a pagar - financeiramente ou outra moeda usada na troca - pelo que lhe é oferecido, de acordo com o benefício agregado por este produto ou serviço (Porter, 1985; Zeithaml, 1988). Assim, ele é positivo quando o cliente entende que as vantagens em uma transação superam os custos totais de propriedade/obtenção (Faria \& Costa, 2005; Kotler \& Keller, 2006).

Prahalad e Ramaswamy (2004b) sugerem que o modelo tradicional da cadeia de valor desenvolvida por Porter (1980) é unilateral, apesar da divisão das atividades empresariais entre principais e de apoio, e foca o ponto de vista apenas da organização, com os papéis de empresa e cliente claramente distintos: produção e consumo, respectivamente. Desta forma, a busca pela criação de mais valor ocorre com a empresa avaliando o que acredita ser melhor para o consumidor e uma constante procura pelo seu cliente definido como target (Kotler \& Keller, 2006). Nesse modelo, a interação cliente-empresa não é vista como fonte de geração de valor (Wikstrom, 1996; Normann \& Ramírez, 2005). 
Com a massificação da Internet, os consumidores têm aumentado seu engajamento em um diálogo ativo e explícito com provedores de produtos e serviços, resultando em diálogos não mais controlados pelas corporações. Consumidores individuais podem iniciar o diálogo, endereçar e aprender sobre negócios, por vezes sozinhos ou mediante conhecimento coletivo de outros consumidores, saindo do papel de meros espectadores para o de atores, ativos. Do ponto de vista da empresa, para que haja participação do cliente, é importante que o canal de distribuição da experiência possua ambiente convidativo. Caso contrário, é possível que frustre as expectativas do consumidor e que a satisfação com o produto, serviço, marca ou empresa sofra uma queda.

Segundo Prahalad e Ramaswamy (2000, 2004b), para conseguir absorver a "competência" [ou essência] do consumidor em prol de seu produto ou serviço, a empresa precisa, no mínimo, enfrentar quatro realidades fundamentais no aproveitamento da competência do consumidor:

- Envolver seus consumidores em um diálogo ativo, explícito e em curso, de igual para igual: entender o que o consumidor quer dialogar é fundamental; não adianta apresentar informações que ele é capaz de buscar em outros meios;

- Mobilizar comunidades de clientes, afinal, estas comunidades podem exercer grande influência no mercado: comunidades virtuais com foco em determinado produto, serviço, empresa, marca são fáceis de formar e de incorporar novos membros; notícias espalham-se muito rapidamente no meio online: virtual marketing;

- Gerir as diferenças entre clientes: clientes são diferentes e devem ser observados de acordo com essas diferenças, que não podem ser ignoradas;

- Cocriar experiências personalizadas com os clientes, permitindo que estes participem da criação do produto ou serviço que irão receber e identifiquem os pontos que lhes são mais relevantes.

Gupta e Lehmann (2005) apontam que a criação de valor sempre possui dois lados - o do consumidor e o da empresa - e a cocriação de valor só ocorre se os pontos de vista de ambas as partes puderem ser expostos concomitantemente. Além disso, é necessário que se pense sobre possíveis alterações na troca de recursos, que podem incluir tanto recompensas 
monetárias quanto benefícios mais intrínsecos e subjetivos e os mecanismos de como as competências dos consumidores e das empresas serão integradas, podendo ocorrer por meio de codesign, codesenvolvimento ou codistribuição (Saarijärvi et al., 2013).

Conforme destacam Prahalad e Ramaswamy (2004b), a cocriação coloca os holofotes diretamente sobre a interação consumidor-empresa como o local de [co]criação de valor, o que significa que todo intercâmbio é crucial para este processo. Passa-se a ter (ou perseguir) um marketing one-to-one, ao invés de segmentado, com os clientes vistos como seres únicos e com desejos, aspirações e necessidades de experiências individuais.

Prahalad e Ramaswamy (2003) apontam que as empresas devem se preparar para fornecer mais do que simplesmente um conjunto de opções para o consumidor. Devem estar preparadas para fomentar as interações e os resultados particularizados. Os clientes deixam o papel de optantes de determinados elementos fornecidos pela empresa para assumir o papel de instigadores e colaboradores de processos que gerarão resultados individualizados.

Assim, a experiência personalizada de cocriação reflete em como o indivíduo escolhe interagir com o ambiente fornecido - mas sem imposição sobre a forma de uso - que a empresa proporciona, tornando o mercado um espaço de potenciais experiências de cocriação onde restrições e escolhas individuais definem o quanto o consumidor está disposto a pagar pela experiência.

O modelo de ambiente propício à interação consumidor-empresa que resulte em cocriação de valor formulado por Prahalad e Ramaswamy (2004a) baseia-se em quatro pilares, resumidos pela sigla DART (Diálogo, Acesso, Risco-Benefício e Transparência).

Levine, Locke, Searls e Weinberger (2001) ressaltam que mercados podem ser vistos como um conjunto de conversas entre o consumidor e a empresa. Desta forma, o diálogo, visto como uma síntese de interação, profundo envolvimento, habilidade e comprometimento de ação de ambas as partes - empresa e consumidor -, é considerado elemento fundamental para a cocriação. Ele implica troca de conhecimentos, problemas e soluções, criando e mantendo uma comunidade fiel à empresa. 
O diálogo torna-se produtivo se ambas as partes tiverem acesso ao mesmo tipo de informação, no mesmo grau. Com a disseminação da Internet e possibilidade de conexão a qualquer momento do dia, as informações relevantes podem ser obtidas tanto por meio de disponibilização da própria empresa quanto por outros consumidores, agrupados em comunidades virtuais. De todo o modo, o acesso fornece ferramentas para enriquecer o diálogo e produzir valor.

Outra dimensão do modelo de Prahalad e Ramaswamy (2004b) é a percepção do riscobenefício pelo consumidor. Cada vez mais, os consumidores querem ser informados sobre os riscos (definidos como a probabilidade de dano de qualquer ordem) que estão correndo ao tomarem a decisão de interagir com o produto ou serviço, bem como as metodologias utilizadas pela empresa para a avaliação dos riscos individuais e sociais.

Por fim, os autores destacam a importância de transparência nas relações. É apenas com informações claras que os consumidores são capazes de tomar decisões conscientes e avaliar os benefícios obtidos com a obtenção do produto ou serviço da empresa fornecedora, desenvolvendo, assim, uma relação de confiança entre as partes. Com o farto acesso às informações provenientes de outros consumidores e ampliação das opções de empresas fornecedoras de produtos ou serviços em função da globalização resultante da popularização da Internet, questionamentos sobre preço, custos e margem de lucro passam a ser levantados, trazendo à tona discussões sobre estes temas e melhores avaliações sobre riscos-benefícios.

Payne et al. (2008) apontam o baixo conhecimento de como os consumidores são envolvidos na cocriação de valor, apesar de este ser ponto fundamental da abordagem da lógica de serviço dominante ( $S$-D logic approach), conforme discutido na Subseção 3.1.1. Em seu artigo, os autores apresentam uma estrutura conceitual do processo para entendimento e melhoria da cocriação de valor no contexto da abordagem $S$-D logic, na tentativa de suprir a falta de modelos objetivos sobre como é feita a cocriação do valor.

O modelo desenvolvido por Payne et al. (2008) foi baseado na literatura existente a respeito de valor, cadeia de valor, cocriação, lógicas dominantes, relacionamento de marketing e comportamento do consumidor. Em uma primeira revisão, foram incorporados 
achados de uma pesquisa qualitativa; outros novos refinamentos ocorreram a partir de séries de workshops e entrevistas com altos gerentes e executivos de grandes corporações com diferentes atuações na área de Serviços, de diferentes países. Por fim, em artigo publicado em 2009, Payne, Storbacka, Frow e Knox incorporaram discussões acerca da marca, até que fosse obtido o modelo final, sintetizado na Figura 3. Este modelo parte do princípio de que, para a abordagem da lógica de serviço dominante, marketing pode ser visto como um conjunto de processos (procedimentos, tarefas, atividades, mecanismos e interações) e recursos com os quais a empresa procura criar proposições de valor e que, coletivamente, suportam a cocriação de valor.

Observando o esquema estruturado na Figura 3 nota-se que o modelo está pautado em quatro principais componentes:

- Processos de criação de valor do consumidor: série de atividades realizadas pelo consumidor para atingir um determinado objetivo. Essas atividades ocorrem por meio de experiências de relacionamento e devem ser vistas como dinâmicas, interativas, não lineares e, muitas vezes, até mesmo inconscientes. Fazem parte deste conjunto de experiências as comunidades de consumidores, as interações entre consumidores, além da participação no desenvolvimento de inovações e design. De forma cíclica, as habilidades dos consumidores de cocriação são desenvolvidas, reforçadas e alteradas em função dos resultados das experiências individuais somadas a fatores externos ou originados pelos fornecedores;

- Processos de criação de valor do fornecedor: atividades que o fornecedor utiliza para gerenciar seu negócio e seus relacionamentos com os clientes e outros stakeholders relevantes. Devem iniciar com o entendimento dos processos de criação de valor do consumidor, identificando quais deles suportar. Segundo Storbacka e Lehtinen (2001), o consumidor é capaz de produzir valor de forma independente, desde que com o suporte do fornecedor. Uma vez que a empresa apoia a cocriação de valor por meio da entrega de experiências que englobem oportunidades e planejamento suportados pelas implementações dos processos e futuras avaliações de métricas, seu conhecimento sobre como proceder para resultar em maior valoração dos serviços também aumenta; 
- Encontros: Interação e trocas entre consumidores e prestadores de serviços. Precisam ser administrados - papel da empresa - para que haja o desenvolvimento de oportunidades de sucesso em cocriação. Estes encontros podem ser "de comunicação" (atividades que promovam diálogos, como propagandas), "de uso" (relacionamentos com uso do serviço pelo cliente, como internet banking) ou "de serviço" (interação pessoal ou de aplicação do serviço pelo prestador, como contato via call center) e são também classificados entre emotivos, cognitivos e comportamentais, dependendo da forma de abordagem para impactar o consumidor. É importante destacar que nem todos os encontros são igualmente importantes para a cocriação de valor; alguns são úteis apenas para que seja possível a construção da experiência, enquanto outros são essencialmente críticos para a cocriação de valor;

- Impacto de fontes adicionais de conhecimento de marca: o conhecimento sobre a marca pode influenciar as percepções sobre ela (Keller, 2003). Este conhecimento pode trazer grandes vantagens em um mercado competitivo e interações "patrocinadas" pelas marcas, como comunidades na Internet, interações de funcionário com consumidor etc, podem provocar processos de cocriação de valor, inclusive com inovações de uso não antes percebidas pelas empresas.

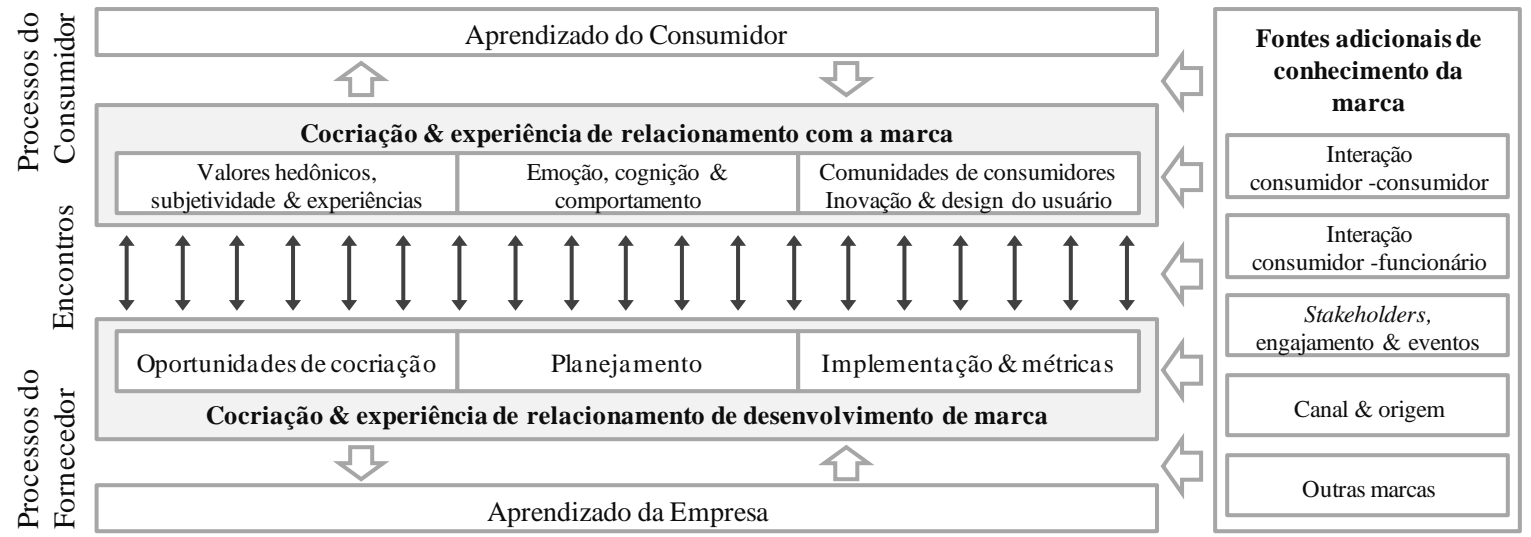

Figura 3. Modelo de cocriação de experiência de relacionamento com a marca. Adaptado pela autora de Payne et al., 2009, p. 382 
Usando como ponto de partida os estudos de Vargo e Lusch (2006, 2008 e 2011), Grönroos (2011) inicia seu artigo discorrendo a respeito da premissa 6 desenvolvida por Vargo e Lusch (2006) na abordagem da lógica de serviço dominante ( $S$-D logic approach): “O consumidor é sempre um cocriador de valor”. Segundo o autor, após a divulgação desta premissa - obtida depois de reformulação daquela desenvolvida em 2004, onde a palavra coprodutor encontrava-se no lugar de cocriador, conforme destacado na Subseção 3.1.1-, os textos seguintes de diversos autores, quando a abordagem é citada, repetem a frase como verdade, sem muito avaliar o real significado desta afirmação e como exatamente ocorre o processo da criação de valor.

Durante o texto, Grönroos (2011) discute as premissas da abordagem da lógica de serviço dominante, além de responder a questionamentos acerca de valor, [co]criação de valor e o papel de cada ator (consumidor e empresa) durante o processo desta criação.

$\mathrm{O}$ primeiro ponto refere-se à definiç̧ão de valor. $\mathrm{O}$ autor, embora reconheça haver diversas descrições, considera que

valor para o consumidor significa que depois de terem sido assistidos por um processo de autosserviço (cozinhar uma refeição ou retirar dinheiro de um caixa automático) ou um processo de serviço completo (comer em um restaurante ou retirar dinheiro no caixa de uma agência bancária) eles estejam ou se sintam melhor que antes (Grönroos, 2008, p. 303)

Esta definição implica que o valor é uma percepção pessoal, uma vez que apenas o indivíduo é capaz de determinar o quanto é necessário para que se sinta melhor do que estava antes de receber o serviço.

Com uma definição objetiva de valor, Grönroos (2011) persegue o entendimento sobre o processo de criação de valor e, mais que isso, o processo de cocriação de valor. Especialmente abordando qual o momento de participação de cada um dos atores (empresa e consumidor).

Conforme apontado pelo autor, quando utilizada a expressão de cocriação de valor, tem-se a impressão de que este processo ocorre de forma consciente - e durante todo o desenvolvimento do serviço/produto - por parte do consumidor. Ao contrário, o autor 
defende que, na maior parte das vezes, o valor é experimentado de uma forma inconsciente e emerge, do ponto de vista do consumidor, apenas durante o fornecimento do serviço ou uso do produto. Assim, conforme destacado anteriormente (Subseção 3.1.2), para Grönroos (2011), o valor de um serviço pode ser visto como o valor em uso e, consequentemente, a criação de valor só pode ser entendida como "uma percepção experimental do valor em uso que emerge do uso ou possessão de recursos, ou mesmo de estados mentais". Logo, design, desenvolvimento e manufatura dos recursos, além de processos de back-office, não podem ser considerados parte da criação de valor para o cliente, exceto em situações bastante específicas quando o consumidor é envolvido nestas etapas.

No cenário em que o consumidor, como usuário, é o responsável pela criação do valor [de usuário para usuário], a criação de valor ocorre com a integração entre os recursos fornecidos pela empresa (design, desenvolvimento, manufatura, entrega) e outros recursos disponíveis no processo de autosserviço. Desta forma, apesar de a empresa, de forma geral, não poder ser vista como cocriadora de valor em termos iguais aos do cliente, entende-se que o papel da empresa é o de facilitadora da criação de valor aos consumidores (Grönroos, 2008). Exceção é feita quando há interação direta entre empresa e consumidores. Nesta situação, os consumidores podem influenciar os processos de produção da empresa e a empresa obtém uma oportunidade de influenciar o processo de uso do cliente. Como a criação de valor ocorre durante o uso, esta última influência faz com que a empresa tenha a oportunidade de fazer parte do processo de criação de valor, tornando-se cocriadora. Grönroos (2011) defende que sem a interação, os consumidores são criadores de valor independentes e, portanto, que "se não há interações diretas, não é possível a cocriação de valor”.

Do ponto de vista da empresa, para que ela exerça a influência sobre a criação de valor tornando-se cocriadora, é importante que seus empregados entendam as necessidades e expectativas dos consumidores, para que possam interagir com eles da melhor forma possível.

A Figura 4 sintetiza as funções de empresa e consumidor, alocando o envolvimento em uma linha do tempo. Neste modelo tem-se uma separação bastante clara do papel de cada ator, com a empresa sendo a responsável pela produção (design, desenvolvimento, 
manufatura, entrega) e o consumidor o responsável pela criação de valor. Quando há a interação entre as partes, é possível que o consumidor torne-se coprodutor e a empresa, cocriadora de valor.

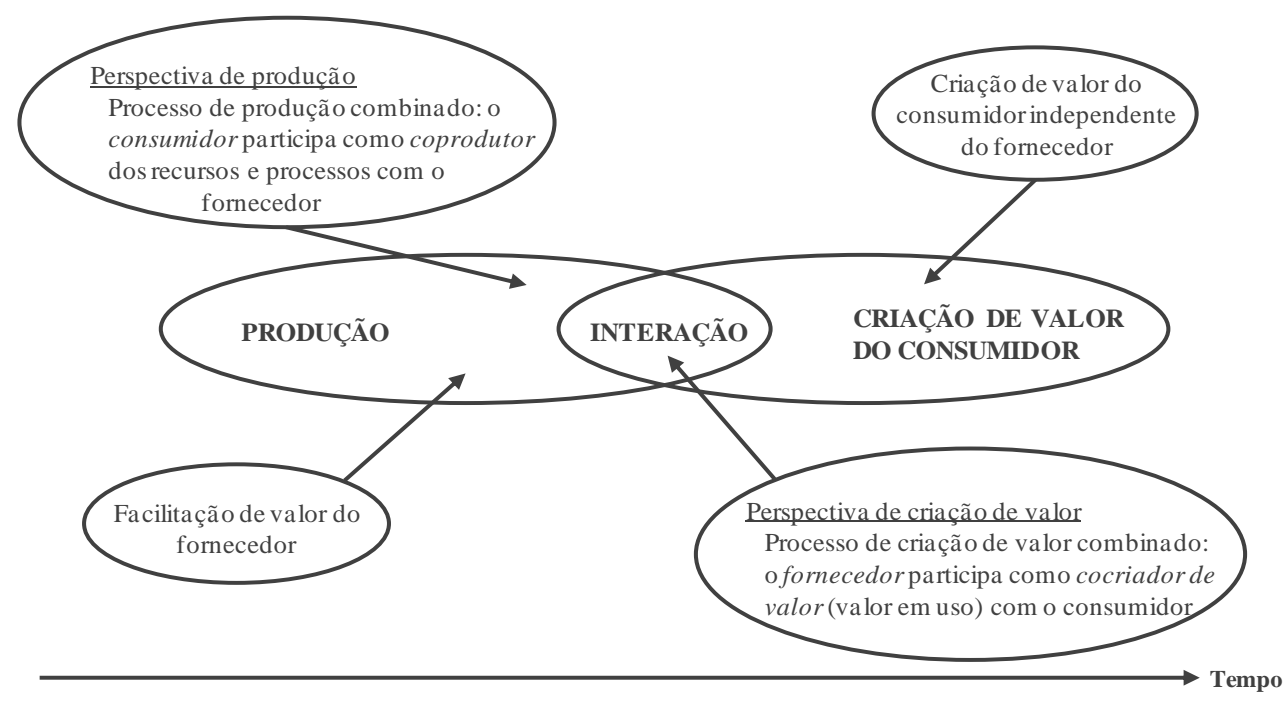

Figura 4. Modelo de criação de valor em uso. Adaptado pela autora de Grönroos, 2011, p. 291

Com o objetivo de criar um modelo teórico que pudesse quantificar a cocriação de valor, Ranjan e Read (2016) desenvolveram um modelo com base em levantamento bibliográfico sobre o tema. Tomando como ponto de partida os estudos de Prahalad e Ramaswamy (2000) e o conceito da abordagem da lógica de serviços, os autores realizaram busca em pesquisas acadêmicas entre 2000 e 2012 que tratavam da cocriação de valor discutida em diversas áreas de estudo, como experiência econômica, marketing, comportamento do consumidor etc.. Como resultado, foi possível identificar a existência de duas vertentes importantes na definição da cocriação de valor: coprodução (engloba o aspecto de troca) e valor em uso (engloba o conceito de que valor sempre é criado durante o uso), que são relevantes e complementam-se, não sendo coerente tratar de cocriação de valor desconsiderando qualquer uma delas.

Uma vez definidos os pilares do conceito de cocriação de valor, Ranjan e Read (2016) focaram na determinação de cada um dos elementos que compõem essas dimensões. Para 
tanto, avaliaram os artigos que haviam levantado, identificaram os conceitos teóricos apontados em cada um deles e separaram os quesitos considerados fundamentais no maior número de estudos. Chegaram, então, a três subdimensões para cada uma das dimensões indicadas anteriormente:

- Coprodução: [Compartilhamento de] Conhecimento, Transparência e Interação;

- Valor em Uso: Experiência, Personalização e Relacionamento.

$\mathrm{Na}$ etapa seguinte, os autores desenvolveram escala para descrever cada uma das subdimensões, por meio de pesquisa qualitativa e levantamento de escalas válidas na literatura. A Tabela 6 apresenta a versão final dos itens considerados para a coprodução e valor em uso na escala desenvolvida por Ranjan e Read (2016) para a representação da cocriação de valor.

Tabela 6

Dimensões referentes à cocriação de valor segundo Ranjan e Read(2016)

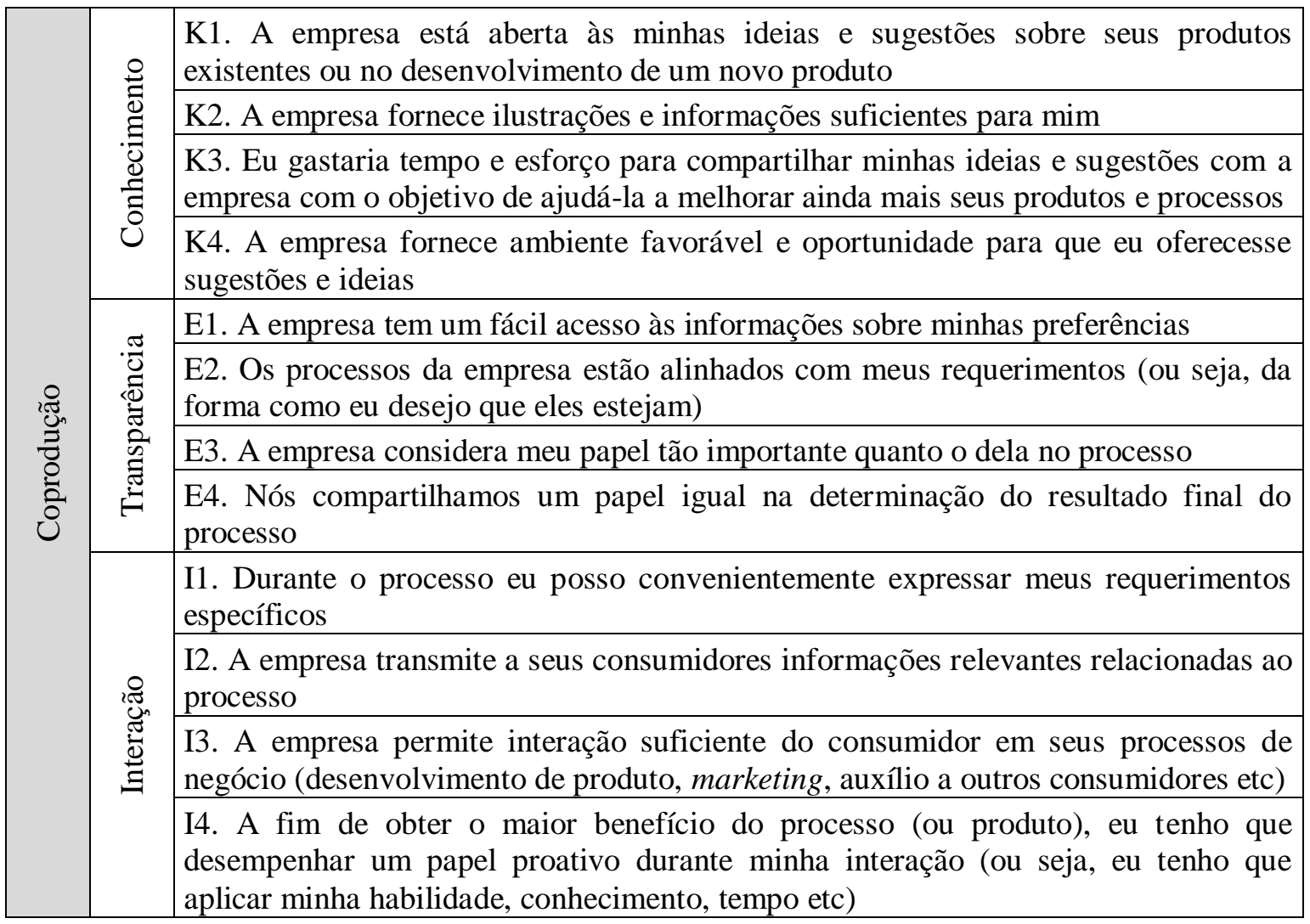




\begin{tabular}{|c|c|c|}
\hline \multirow{11}{*}{ 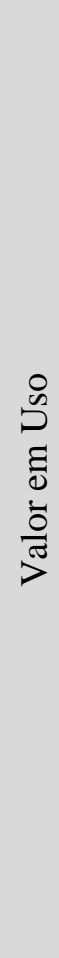 } & \multirow{3}{*}{ 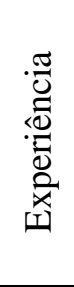 } & $\begin{array}{l}\text { X1. É uma experiência memorável para mim (ou seja, a memória do processo durará } \\
\text { um bom tempo) }\end{array}$ \\
\hline & & $\begin{array}{l}\text { X2. Dependendo da natureza da minha própria participação, as minhas experiências } \\
\text { no processo podem ser diferentes das de outros consumidores }\end{array}$ \\
\hline & & $\begin{array}{l}\text { X3. É possível para um consumidor melhorar o processo pela experimentação e } \\
\text { tentativa de novas coisas }\end{array}$ \\
\hline & \multirow{4}{*}{ 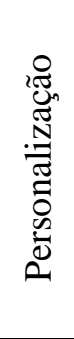 } & $\begin{array}{l}\text { P1. O benefício, valor ou divertimento do processo (ou produto) depende do usuário } \\
\text { e sua condição de uso }\end{array}$ \\
\hline & & $\begin{array}{l}\text { P2. A empresa tenta servir às necessidades individuais de cada um de seus } \\
\text { consumidores }\end{array}$ \\
\hline & & $\begin{array}{l}\text { P3. Cada consumidor, dependendo de seu gosto, escolha ou conhecimento, envolve- } \\
\text { se diferentemente no processo (ou com o produto) }\end{array}$ \\
\hline & & P4. A empresa fornece, no geral, uma boa experiência, além do benefício "funcional" \\
\hline & \multirow{4}{*}{ 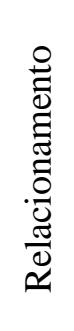 } & $\begin{array}{l}\text { R1. A facilitação estendida da empresa é necessária para os consumidores } \\
\text { desfrutarem plenamente do processo (ou do produto) }\end{array}$ \\
\hline & & R2. Eu sinto um apego ou relacionamento com a empresa \\
\hline & & $\begin{array}{l}\text { R3. Havia geralmente um grupo, uma comunidade ou uma rede de consumidores que } \\
\text { eram fãs da empresa }\end{array}$ \\
\hline & & $\begin{array}{l}\text { R4. A empresa foi reconhecida porque seus consumidores costumavam espalhar } \\
\text { palavras positivas sobre ela em suas redes sociais }\end{array}$ \\
\hline
\end{tabular}

Nota. Traduzido de Ranjan e Read, 2016, p. 301.

Ao final do processo, os autores chegaram à definição de cocriação de valor como sendo um construto de terceira ordem, formativo, composto de dois outros construtos de segunda ordem, também formativos - coprodução e valor em uso -, que, por sua vez, foram compostos por outros três construtos formativos cada, os quais eram constituídos por três ou quatro indicadores. A Figura 5 expõe o modelo completo. 


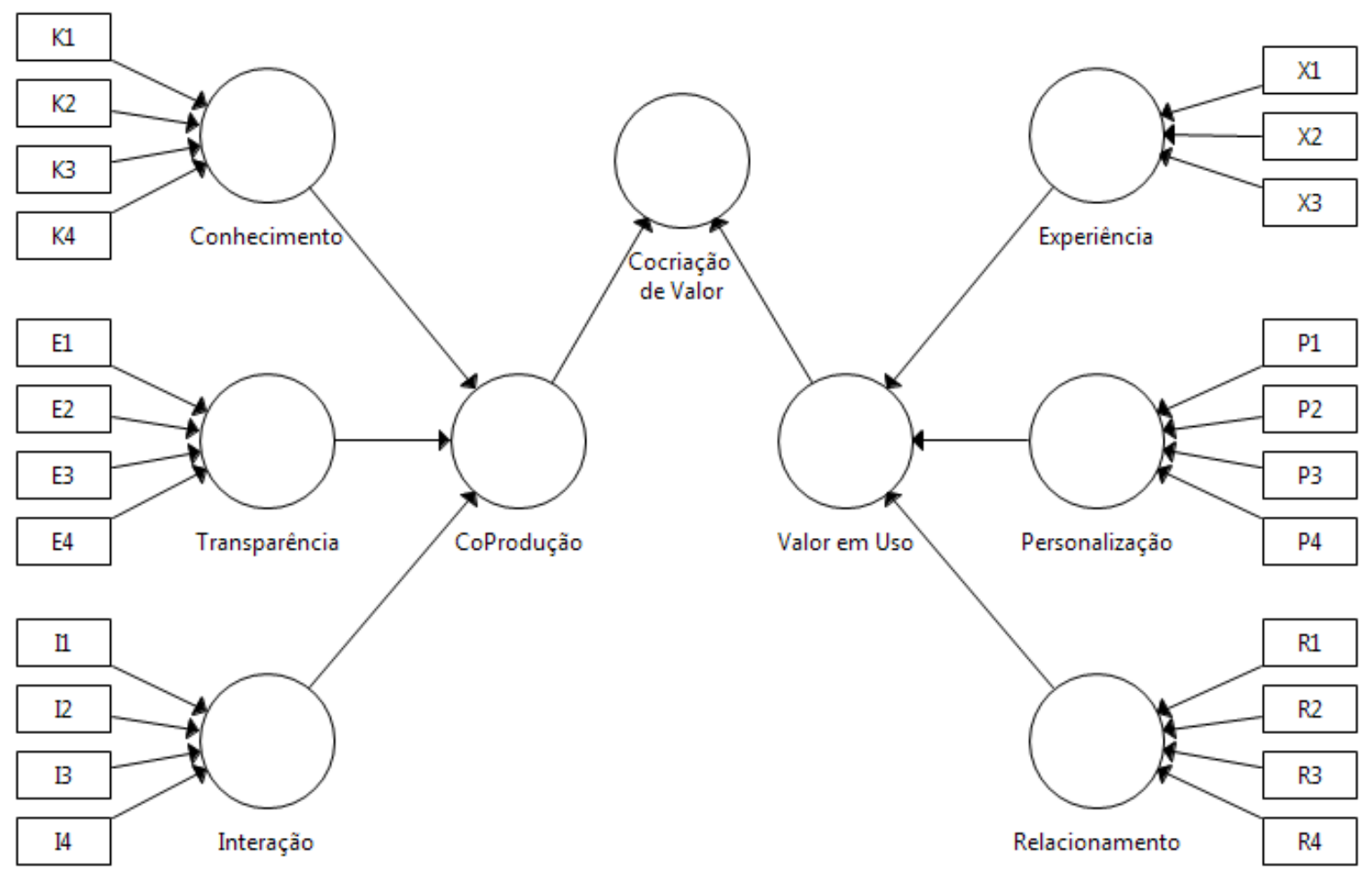

Figura 5. Cocriação de valor: modelo de mensuração (formativo-formativo). Adaptado de Ranjan e Read, 2016, p. 303

Embora o foco deste estudo seja a cocriação de valor e a interação entre sistemas de serviço tenha por objetivo resultar em valoração, Plé e Cáceres (2010) apontam que esta interação pode resultar em uma codestruição de valor - ou cocriação negativa. Um exemplo apontado pelos autores refere-se a consumidores que compram carros, mas não os mantêm, usam de forma incorreta ou que culpam a empresa por algum tipo de problema que tenham tido, reduzindo assim, o valor do produto ou serviço, ao que chamaram de codestruição. Plé e Cáceres (2010) defendem que a cocriação de valor por meio da interação entre os agentes do sistema de serviço depende das expectativas de todos os envolvidos acerca dos recursos que devem ser empregados por cada um. Quando estas expectativas não convergem, como quando o consumidor não possui conhecimento $\mathrm{o}$ suficiente para utilização do serviço que lhe está sendo oferecido (por exemplo, em casos de produtos inovadores), pode resultar em codestruição no valor em função do que os autores chamaram de mau uso dos recursos. Neste caso, a codestruição ocorre de forma não intencional. Há, porém, aquelas intencionais. Plé e Cáceres (2010, p. 434) apontam que 
um ou outro elemento algumas vezes tem interesse em fazer mau uso dos recursos. Tal uso intencional de recursos normalmente ocorre quando um dos agentes do sistema de serviço procura aumentar seu próprio bem estar e capacidade de adaptação em detrimento do bem estar e capacidade adaptativa de outro agente. Desta forma, o mau uso intencional implica a existência de valores desequilibrados, com efeitos prejudiciais (codestruição de valor) por parte de um dos agentes do sistema de serviço, enquanto o outro experimenta benefícios (cocriação de valor).

Um dos exemplos descritos com relação a esta codestruição intencional diz respeito às centrais de Call Center, onde os consumidores esperam ser atendidos por operadores com conhecimento do negócio e tenham seus problemas resolvidos na primeira ligação. Os operadores de telemarketing, porém, possuem uma meta de diminuição do tempo de atendimento, resultando em atendimentos menos produtivos. Desta forma, do ponto de vista do cliente, o recurso (operadores) não é usado do modo correto, fazendo com que a percepção seja de não atendimento intencional, resultando, assim, em uma codestruição de valor. Já para a empresa, o resultado é de diminuição do custo de pessoal, por ser mais produtivo, implicando uma cocriação de valor (Singh, 2000). Interações de alta qualidade que permitam que um cliente individual cocrie experiências únicas com a empresa são a chave para destravar novas fontes de vantagem competitiva.

Conforme abordado em algumas passagens desta seção, espera-se que a cocriação de valor possua relação positiva com satisfação e lealdade do consumidor a determinada empresa ou serviço, uma vez que o consumidor passa a assumir um papel ativo e a criar valor junto com a empresa, coproduzindo um serviço ou produto que satisfaça suas necessidades. A próxima seção apresenta definições de satisfação e lealdade.

\subsection{Satisfação e Lealdade}

Apesar de a satisfação ser amplamente discutida em estudos que englobam diferentes áreas do setor de serviços, Velázquez et al. (2011) destacam a existência de diversas definições, ora com foco em uma perspectiva cognitiva e/ou afetiva, ora com foco em uma perspectiva prática, considerando a natureza de uma transação específica. Segundo as autoras, esta falta de objetividade acarreta dificuldade na obtenção de medidas (escalas) válidas e na comparação entre resultados de pesquisas. 
Para a área educacional, especificamente, embora também não haja um consenso estabelecido para a definição de satisfação, há uma concordância entre pesquisadores de que a satisfação exerce influência positiva na lealdade do estudante perante o curso e/ou a universidade (Mantovani, 2012).

Para o modelo proposto por Mantovani (2012) em seu estudo sobre educação a distância, foram utilizadas escalas desenvolvidas a partir dos achados de Gruber, FuB, Voss e GläserZikuda (2010) e Udo, Bagchi e Kirs (2011). Os primeiros definem que a satisfação é resultado do quanto o estudante avalia como positivas as suas experiências de aprendizado. Para Gruber et al. (2010), qualidade percebida, preço, fatores pessoais e de ambiente são elementos que compõem a satisfação do aluno. Já Udo et al. (2011) apresentam a satisfação como sendo uma resposta do consumidor a um serviço que ele acreditou ter sido bem prestado, resultando em sensações positivas.

Embora muitas vezes a lealdade do consumidor seja considerada apenas do ponto de vista comportamental como um processo de repetição de compra, Velázquez et al. (2011, p. 67) apontam três importantes visões sobre este tema:

- Comportamental, que reflete a repetição de compra de produto ou nova aquisição de serviço igual ou diferente de mesma empresa;

- Atitudinal, que inclui a recomendação do serviço a conhecidos e intenção de recompra;

- Complexa, que combina ambos os componentes anteriores.

Com o objetivo de conceituar de forma objetiva esta dimensão, Aksoy et al. (2014) avaliam a necessidade de quatro itens fundamentais em seu conceito: (1) percepção de relação especial; (2) tratamento favorável aos objetos de lealdade; (3) desejo de manter o relacionamento mesmo quando sacrifícios são necessários e (4) defesa e reforço do relacionamento, definindo-a como "Lealdade é o reconhecimento do quão especial é um relacionamento, o que resulta em um tratamento diferenciado e mais favorável a esta relação, na criação de um vínculo como resultado desta relação e na defesa e reforço deste relacionamento" (Aksoy et al., 2014, p. 38). 
É importante ressaltar que, apesar de satisfação não garantir lealdade, é esperada relação positiva entre as duas características, considerando que consumidores leais estão satisfeitos (Jones \& Sasser, 1995).

Dimensão relevante para a determinação da satisfação do consumidor - e sua consequente lealdade -, a próxima seção abordará a qualidade percebida, apontando modelos amplamente estudados para sua obtenção.

\subsection{Qualidade Percebida}

Conforme levantamento realizado por Mantovani (2012) acerca dos mitos que envolvem a educação a distância, a percepção de menor qualidade e as dúvidas sobre o grau de efetividade em relação ao ensino tradicional são evidentes.

De acordo com Gianesi e Correa (1996), principalmente as características de intangibilidade, inseparabilidade e perecibilidade afetam significativamente a qualidade dos serviços prestados e a percepção dos consumidores em relação à qualidade. $\mathrm{Na}$ área de educação, Gruber et al. (2010, p.107) destacam que "qualidade no ensino superior é um conceito complexo e multifacetado", dependendo dos pontos de vista dos diferentes entes envolvidos no processo educacional - cuja avaliação sofre influência das necessidades individuais de cada um.

A partir de grupos-foco, Parasuraman, Zeithaml e Berry (1988) constataram que, de forma geral, era possível generalizar em um questionário com escala do tipo Likert de sete pontos, os critérios que mediam expectativa e percepção de desempenho por meio de cinco dimensões de qualidade compostas por 22 perguntas. Esta abordagem é chamada de SERVQUAL. A partir destas medidas de expectativa (E) e as percepções (P) dos clientes em relação ao serviço prestado, obtém-se a qualidade do serviço $(\mathrm{Q})$ usando $\mathrm{Q}=\mathrm{P}-\mathrm{E}$. São as dimensões da SERVQUAL (Salomi et al., 2005): Confiabilidade, Presteza, Segurança, Empatia e Aspectos Tangíveis. 
Em contraste ao SERVQUAL, Cronin Jr. e Taylor (1992) propuseram uma abordagem partindo do pressuposto que a qualidade não deve ser medida por meio das diferenças entre expectativa e desempenho e sim apenas como uma percepção do desempenho (modelo SERVPERF). Considerando fundamentados os 22 itens em cinco dimensões propostos por Parasuraman et al. (1988), testaram validade e discriminação de ambos os modelos e concluíram que o instrumento por eles desenvolvido é mais sensível em retratar as variações de qualidade em relação às outras escalas testadas. Os autores concluíram, também, que a qualidade de serviço conduz à satisfação do cliente e que o nível de qualidade perceptível do serviço redefinido modifica a intenção de recompra de um cliente (lealdade).

De forma geral, o modelo SERVPERF pode ser representado por $\mathrm{Qj}=\mathrm{Pj}$, sendo $\mathrm{Qj}$ a avaliação da qualidade do serviço em relação à característica j e $\mathrm{Pj}$ os valores de percepção de desempenho para a característica j de serviço (Salomi et al., 2005).

Mantovani (2012), utilizando como base o modelo SERVPERF, apresenta escala específica para educação a distância considerando as cinco dimensões consolidadas, com foco na percepção de desempenho.

As seções seguintes discutem serviço e cocriação de valor sob a ótica da educação - e EaD -, entendendo, primeiramente onde se encaixam as relações entre estudantes, professores e universidade no contexto de consumidores e provedores e, em seguida, as hipóteses acerca da cocriação de valor neste ambiente específico.

\subsection{O Ensino Superior visto sob a Perspectiva do Serviço}

Embora a relação entre estudante e universidade possa ser presumida uma relação de prestação de serviço, com o aluno no papel de consumidor, muito se discute a respeito desta definição sob os preceitos do marketing. 
Analisando o estudante sob o ponto de vista estrito daquele que realiza uma compra, que troca o serviço fornecido pela universidade por dinheiro, ele pode ser visto e deve ser tratado como um consumidor comum, como de qualquer outro tipo de produto ou serviço, com suas obrigações e deveres (Kanji \& Tambi, 1999; Bennet, 2003). Eagle e Brennan (2007), entretanto, argumentam que, considerando que o objetivo ao cursar o ensino superior é o de obter uma qualificação, então, tratar estudantes como consumidores no sentido de que os prestadores de serviço devem fornecer o melhor possível dentro daquilo que é importante para seus clientes, de forma a manter a máxima de que "os consumidores têm sempre razão", pode corroer o processo educacional e, assim, apesar de, de fato estarem adquirindo um serviço fornecido pela universidade, a conceituação do papel de consumidor não é tão simples para o ambiente do ensino superior.

Clayson e Haley (2005) discutem justamente que se os estudantes forem encorajados a se autoperceberem consumidores, podem ser encorajados a culpar o fornecedor do serviço se seu desempenho ficar abaixo das expectativas; logo, "resultados ruins tornam-se culpa do professor" (Clayson \& Haley, 2005, p. 3).

Para Svensson e Wood (2007), a relação entre estudantes e universidade se inicia com a concepção de que a universidade é provedora do conhecimento e o estudante, seu receptor; porém, os papéis são intercambiáveis entre os dois entes em alguns momentos, fazendo com que o aluno não possa ser visto como um mero consumidor como ocorreria em outros tipos de serviço ou produtos. Destacam-se, também, como singularidades da relação, a impossibilidade de compra da qualificação em si (Sirvanci, 1996; Emery, Kramer \& Tian, 2001) e a avaliação prévia realizada pela universidade das habilidades acadêmicas do potencial aluno, não importando, portanto, apenas a capacidade de pagamento pelo serviço.

Svensson e Wood (2007) defendem, assim, que os estudantes não devem ser vistos como consumidores e sim como cidadãos da comunidade universitária, reforçando o mesmo apontado por Halbesleben, Becker e Buckley (2003), de que ao invés de considerar o estudante como um consumidor faz mais sentido considerá-lo como ente participativo em seu processo educacional. 
Entendidas as peculiaridades da educação a distância como serviço e suas implicações, é possível consolidar os tópicos discutidos até então em um modelo relacional, avaliando os efeitos das dimensões levantadas, especialmente no que diz respeito à cocriação de valor, no contexto EaD. É sobre este modelo que trata o próximo capítulo. 


\section{MODELO TEÓRICO PROPOSTO}

Este capítulo apresenta uma integração entre os Capítulos 2 e 3, com a descrição do modelo de estudo proposto.

Em estudo publicado em 1996, Fornell, Johnson, Anderson, Chang e Bryant apresentaram um modelo que sumariza um índice de satisfação do consumidor americano (American Customer Satisfaction Index - ACSI), com impacto positivo na lealdade do consumidor e negativo em suas reclamações. Segundo os autores, a satisfação sofre influência da qualidade percebida, valor percebido e expectativa do consumidor. De forma adaptada, diversos autores pautaram seus estudos estendendo e variando as relações obtidas no ACSI, ora acrescentando, ora retirando dimensões, mas utilizando-se como base as relações apontadas por Fornell et al. (1996) para a qualidade, satisfação e lealdade (Mantovani, 2012). Embora, como destacado por Masano (2006), haja linhas de pesquisa que entendem a satisfação como antecedente da qualidade percebida, neste trabalho foi utilizado mesmo conceito defendido por Fornell et al. (1996).

Conforme destacado na Seção 1.1, o presente estudo também busca inter-relacionar as dimensões de qualidade percebida, satisfação e lealdade, levando em consideração o papel da cocriação de valor em contexto maior do que de valor percebido: como valor cocriado. Agregando ao conceito de cocriação de valor as relações que foram apontadas ao longo do Capítulo 3, como, por exemplo, que a cocriação de valor influencia na satisfação que, por sua vez, influencia na lealdade (Taylor \& Hunter, 2014) ou que a percepção de valor impacta na lealdade (Ravald \& Grönroos, 1996), obtém-se o modelo esquematizado de modo macro pela Figura 6.

É importante notar que, apesar de no modelo ACSI, o valor percebido ser influenciado pela qualidade percebida, entende-se que, ao se tratar de cocriação de valor, faz sentido que a relação ocorra em sentido inverso, uma vez que o consumidor participa da criação do serviço ou produto, sendo, de certa forma, corresponsável pela geração da qualidade final. 
As hipóteses primárias das relações entre dimensões no contexto de educação a distância podem ser, então, resumidas como disposto a seguir, conforme objetivos (b), (c) e (d) apresentados na Seção 1.1:

H1) Existe uma relação positiva entre cocriação de valor e qualidade percebida;

H2) Existe uma relação positiva entre qualidade percebida e satisfação;

H3) Existe uma relação positiva entre cocriação de valor e satisfação;

H4) Existe uma relação positiva entre satisfação e lealdade;

H5) Existe uma relação positiva entre cocriação de valor e lealdade.

Para que haja a avaliação das relações dispostas na Figura 6, é necessário definir a composição de cada construto. Assim como abordado por Cronin Jr. e Taylor (1992), a qualidade percebida é dita um construto de segunda ordem, obtido por meio de cinco outras dimensões. Já a cocriação de valor é, conforme apresentado por Ranjan e Read (2016), um construto de terceira ordem, composto por duas dimensões de segunda ordem, cada qual composta por três dimensões de primeira ordem. Satisfação e Lealdade são construtos de primeira ordem.

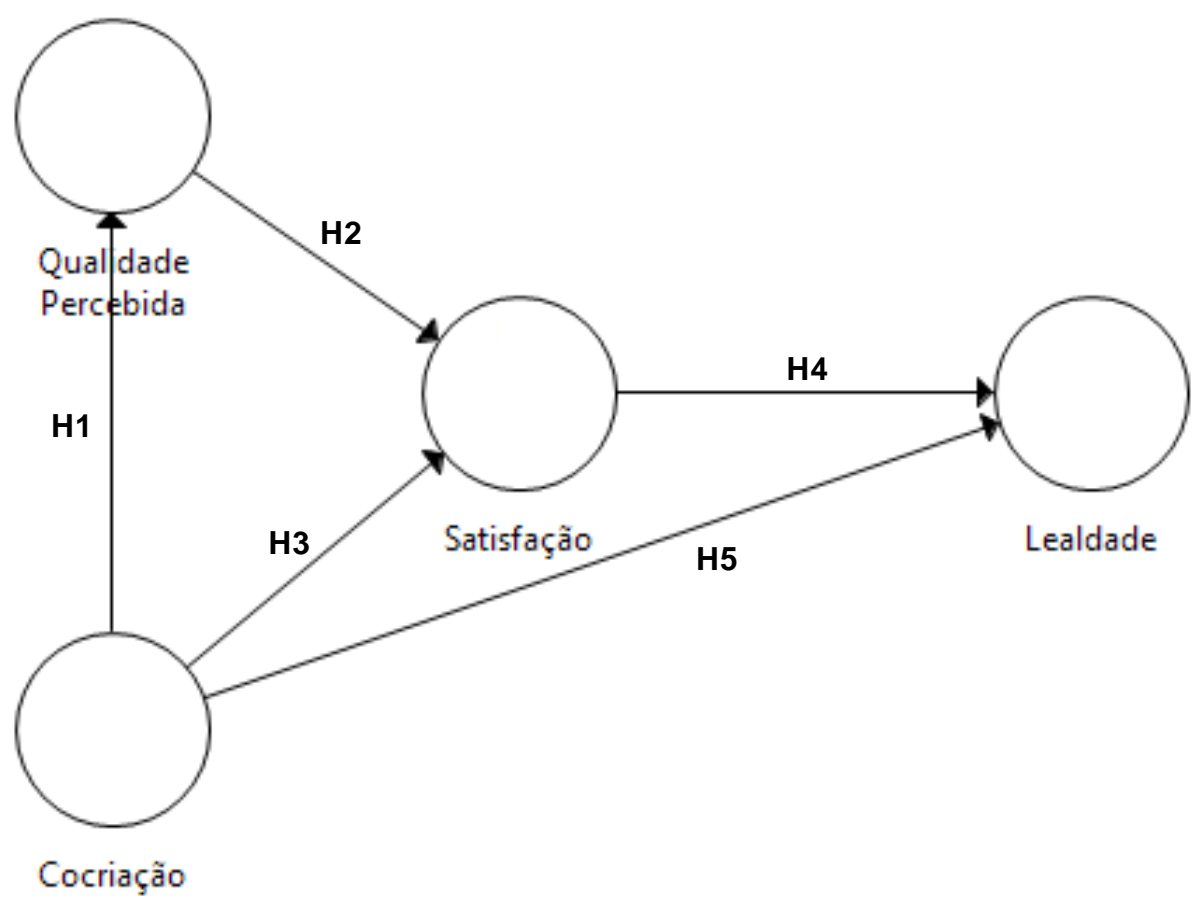

Figura 6. Modelo proposto para relacionamento entre cocriação de valor, qualidade percebida, satisfação e lealdade - visão macro 
No Capítulo 6, o modelo ora proposto será confrontado com um modelo alternativo com a inclusão dos construtos Comprometimento e Imagem; detalhes estão na Seção 6.4.

A próxima seção detalha como foram operacionalizadas as dimensões apresentadas, especificamente para a educação a distância. Demais aspectos metodológicos, como amostragem, tipologia da pesquisa aplicada e softwares utilizados estão presentes no próximo capítulo.

\subsection{Operacionalização das Dimensões}

Anteriormente foram exibidos o modelo conceitual com relações entre dimensões e as respectivas hipóteses de pesquisa que contemplam os objetivos específicos descritos, sem, contudo, detalhar as estruturas de cada um dos aspectos.

Tendo por base o estudo de Mantovani (2012), que tratou de educação a distância, foram definidos os indicadores referentes às dimensões de Qualidade Percebida, Satisfação e Lealdade. A Tabela 7 apresenta as perguntas utilizadas após adaptação do texto desenvolvido por Mantovani (2012) e fase qualitativa da pesquisa (serão discutidos maiores detalhes na Seção 5.1) para cada uma destas dimensões.

É importante ressaltar que a Qualidade Percebida, sendo um construto de segunda ordem, é composta por outros cinco, em linha com o desenvolvido e validado no modelo SERVPERF: Segurança (Garantia), Empatia, Presteza (Capacidade de Resposta), Confiabilidade, Aspectos Tangíveis (Conteúdo do Site). Cada um dos cinco construtos é descrito por indicadores de forma reflexiva, sendo, posteriormente, parte da composição da Qualidade Percebida formativamente (Jarvis, Mackenzie \& Podsakoff, 2003). A Figura 7 delineia esta descrição. 


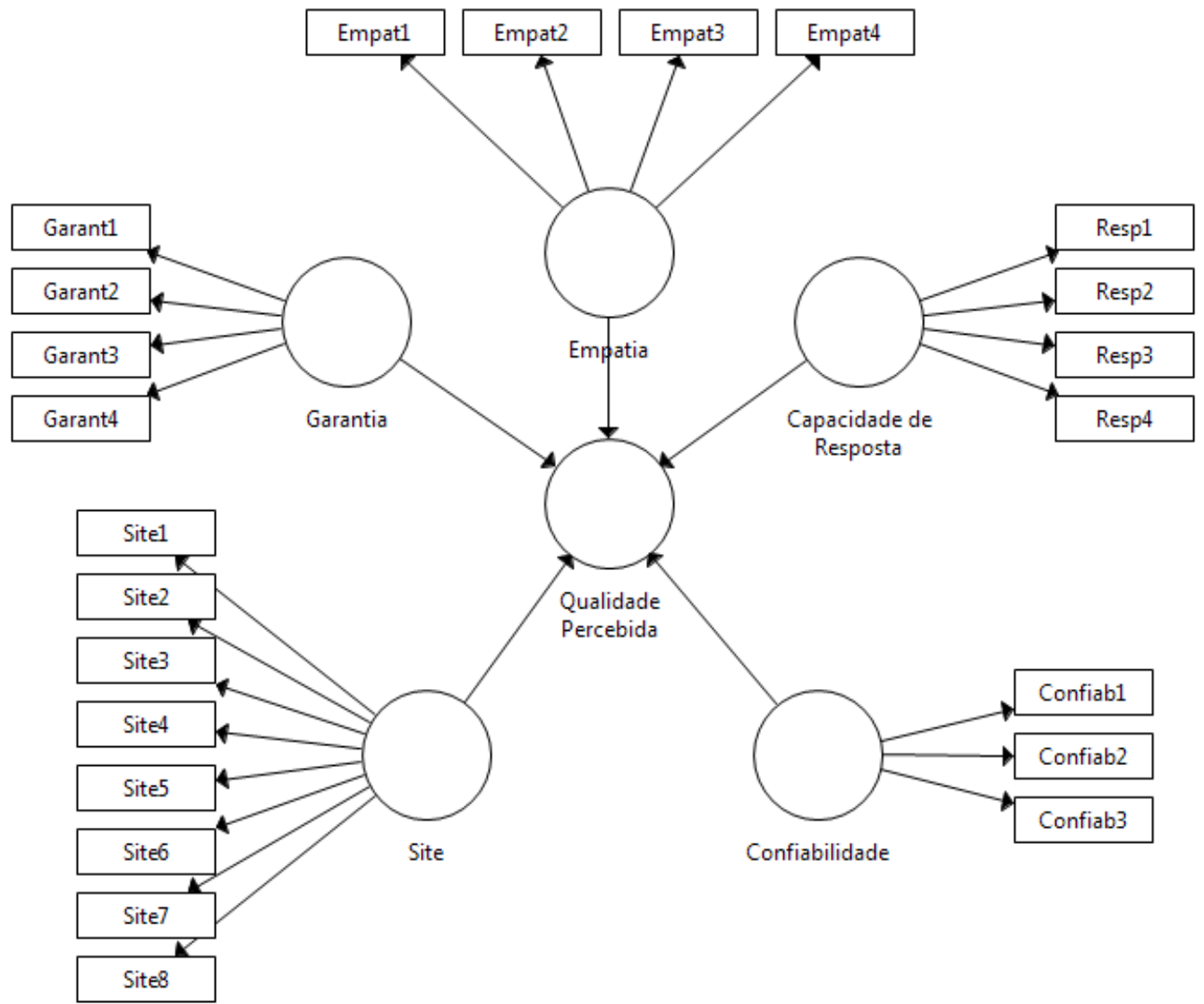

Figura 7. Qualidade percebida: modelo de mensuração

Assim como proposto por Mantovani (2012), neste estudo também foi mantida uma dimensão que refletisse a Qualidade Geral de forma a ser possível realizar eventual correlação com os valores obtidos de forma indireta em uma avaliação de consistência de respostas.

Tabela 7

Dimensões referentes a qualidade percebida, satisfação e lealdade

\begin{tabular}{|c|c|l|}
\hline Dimensão & \multicolumn{1}{|c|}{ Item } & \multicolumn{1}{c|}{ Pergunta/Frase } \\
\hline \multirow{4}{*}{ Garantia } & Garant1 & Os instrutores conhecem profundamente a sua área \\
\cline { 2 - 3 } & Garant2 & $\begin{array}{l}\text { Os instrutores são justos e imparciais ao atribuir notas aos trabalhos e } \\
\text { provas }\end{array}$ \\
\cline { 2 - 3 } & Garant3 & $\begin{array}{l}\text { Os instrutores respondem as dúvidas a eles enviadas de forma } \\
\text { completa e cuidadosa }\end{array}$ \\
\cline { 2 - 4 } & Garant4 & Os instrutores conhecem profundamente os materiais do curso \\
\hline
\end{tabular}




\begin{tabular}{|c|c|c|}
\hline Dimensão & Item & Pergunta/Frase \\
\hline \multirow{4}{*}{ Empatia } & Empat1 & Os instrutores preocupam-se com os alunos \\
\hline & Empat2 & Os instrutores compreendem as necessidades individuais dos alunos \\
\hline & Empat3 & Os instrutores pensam nos interesses de longo prazo dos alunos \\
\hline & Empat4 & $\begin{array}{l}\text { Os instrutores motivam e estimulam os alunos a darem o seu melhor } \\
\text { no curso }\end{array}$ \\
\hline \multirow{4}{*}{$\begin{array}{l}\text { Capacidade de } \\
\text { Resposta }\end{array}$} & Resp1 & Os instrutores são acessíveis fora dos momentos de encontro \\
\hline & Resp2 & Os instrutores dão retorno às solicitações dos alunos rapidamente \\
\hline & Resp3 & $\begin{array}{l}\text { Os instrutores fazem tudo o que podem para ajudar os alunos, mesmo } \\
\text { que isso vá além de suas responsabilidades }\end{array}$ \\
\hline & Resp4 & Os instrutores valorizam perguntas e comentários dos alunos \\
\hline \multirow{3}{*}{ Confiabilidade } & Confiab1 & Considero as aulas muito boas \\
\hline & Confiab2 & Os instrutores inspiram segurança \\
\hline & Confiab3 & Os instrutores dão retorno sobre as tarefas solicitadas \\
\hline \multirow{8}{*}{$\begin{array}{l}\text { Conteúdo do } \\
\quad \text { Site }\end{array}$} & Site1 & Os recursos de áudio utilizados nos cursos são apropriados \\
\hline & Site2 & Os recursos de vídeo utilizados nos cursos são apropriados \\
\hline & Site3 & $\begin{array}{l}\text { O curso utiliza adequadamente ferramentas multimídia (áudio, vídeo, } \\
\text { animações, gráficos) }\end{array}$ \\
\hline & Site4 & O ambiente virtual apresenta informações confiáveis \\
\hline & Site5 & O conteúdo disponibilizado é de alta qualidade \\
\hline & Site6 & O conteúdo apresentado no ambiente virtual é relevante para mim \\
\hline & Site7 & Há flexibilidade de horário para realização das atividades \\
\hline & Site8 & O ambiente virtual de aprendizagem é interativo e dinâmico \\
\hline \multirow{5}{*}{$\begin{array}{l}\text { Qualidade } \\
\text { Geral }\end{array}$} & QG1 & O curso apresenta temas atuais \\
\hline & QG2 & As ferramentas tecnológicas utilizadas no curso funcionam bem \\
\hline & QG3 & O material do curso apresenta as informações de forma clara \\
\hline & QG4 & $\begin{array}{l}\text { Estudar a distância é melhor do que da maneira tradicional } \\
\text { (presencial) }\end{array}$ \\
\hline & QG5 & O curso é de alta qualidade \\
\hline \multirow{4}{*}{ Satisfação } & Satisf1 & Estou satisfeito com minha decisão de estudar a distância \\
\hline & Satisf2 & Acertei ao decidir fazer o curso a distância \\
\hline & Satisf3 & Minha experiência em estudar a distância tem sido agradável \\
\hline & Satisf4 & O curso atende minhas expectativas \\
\hline \multirow{3}{*}{ Lealdade } & Leal1 & Eu recomendaria este curso a distancia aos meus amigos e familiares \\
\hline & Leal2 & $\begin{array}{l}\text { Eu certamente faria outro curso de graduação ou uma pós-graduação a } \\
\text { distância }\end{array}$ \\
\hline & Leal3 & Pretendo chegar ao final do curso \\
\hline
\end{tabular}

Nota. Adaptado de Mantovani, 2012, p. 156 
Conforme destacado na Seção 3.2, Ranjan e Read (2016) propuseram um modelo que tornasse possível a quantificação da cocriação de valor nos preceitos teóricos abordados desde o início da década de 2000, incorporando as duas principais linhas de pesquisa defendidas por Vargo e Lusch (2004), Prahalad e Ramaswamy (2004b) e Grönroos (2008): coprodução e valor em uso.

Utilizando o modelo de Ranjan e Read (2016) como ponto de partida para a operacionalização da dimensão de cocriação de valor, buscaram-se, na literatura sobre Educação, atributos apontados como relevantes para a [co]criação de valor nesta área (Tabela 8) e resultantes da pesquisa qualitativa realizada com coordenadores e diretores de faculdade (serão discutidos maiores detalhes na Seção 5.1 sobre a pesquisa qualitativa e pré-teste realizados), de forma a ser possível adaptar a escala desenvolvida por Ranjan e Read (2016) aos objetivos deste estudo e englobar todos os quesitos entendidos como importantes para a valoração nessa área de pesquisa.

Tabela 8

Atributos e fontes para cocriação de valor

\begin{tabular}{|l|c|}
\hline \multicolumn{1}{|c|}{ Atributos } & Fontes \\
\hline Sucesso profissional & $\begin{array}{c}\text { (Bowden \& D'Alessandro, 2011; Brambilla, } \\
\text { 2010; Ledden \& Anderson, 2015) }\end{array}$ \\
\hline Sucesso acadêmico & $\begin{array}{c}\text { (Bowden \& D'Alessandro, 2011; Brambilla, } \\
\text { 2010; Ledden \& Anderson, 2015) }\end{array}$ \\
\hline Crescimento pessoal & $\begin{array}{c}\text { Bowden \& D'Alessandro, 201; Brambilla, } \\
\text { 2010; Ledden \& Anderson, 2015) }\end{array}$ \\
\hline Tempo gasto com o curso & (Ledden \& Anderson, 2015) \\
\hline Opinião da família & (Ledden \& Anderson, 2015) \\
\hline Opinião dos amigos & (Ledden \& Anderson, 2015) \\
\hline Divulgação na mídia & (Brambilla, 2010) \\
\hline $\begin{array}{l}\text { Desempenho do curso em avaliações do governo } \\
\text { (CAPES) }\end{array}$ & (Brambilla, 2010) \\
\hline $\begin{array}{l}\text { Qualificação dos tutores } \\
\text { Ambiente de ensino }\end{array}$ & (Ledden \& Anderson, 2015) \\
\hline $\begin{array}{l}\text { Atividades acadêmicas extraclasses (trabalhos em } \\
\text { grupo, participações em fóruns ou grupos de } \\
\text { discussão) }\end{array}$ & $\begin{array}{c}\text { (Bowden \& D'Alessandro, 2011; } \\
\text { Brambilla, 2010) }\end{array}$ \\
\hline $\begin{array}{l}\text { Realização de tarefas } \\
\text { Bonderson, 2015) }\end{array}$ \\
\hline
\end{tabular}




\begin{tabular}{|l|c|}
\hline \multicolumn{1}{|c|}{ Atributos } & Fontes \\
\hline Estudo individual extraclasse & $\begin{array}{c}\text { (Bowden \& D'Alessandro, 2011; } \\
\text { Brambilla, 2010) }\end{array}$ \\
\hline $\begin{array}{l}\text { Reprovação ou aprovação do aluno de acordo com a } \\
\text { adimplência da mensalidade }\end{array}$ & (Brambilla, 2010) \\
\hline Nível de exigência dos professores & (Brambilla, 2010) \\
\hline Grau de envolvimento dos alunos pelo professor & (Brambilla, 2010) \\
\hline Preço pago pela mensalidade & (Bowden \& D'Alessandro, 2011; \\
Brambilla, 2010)
\end{tabular}

Nota. Elaborado pela autora

Após as etapas qualitativas e de pré-teste, puderam ser obtidas as perguntas relativas às dimensões que compõem a cocriação de valor, dispostas na Tabela 9, sendo, assim, possível operacionalizar esse construto.

Durante fase de validação de conteúdo (também mais detalhada na Seção 5.1), a pergunta "A faculdade fornece boas experiências, além do benefício de se obter o diploma", adaptada de "A empresa fornecia, no geral, uma boa experiência, além do benefício 'funcional"” desenvolvida por Ranjan e Read (2016) e apresentada como item P4 na Tabela 6, foi alocada no construto Experiência, ao invés do construto Personalização.

Tabela 9

Dimensões referentes à cocriação de valor

\begin{tabular}{|c|l|l|}
\hline Dimensão & \multicolumn{1}{|c|}{ Item } & \multicolumn{1}{c|}{ Pergunta/Frase } \\
\hline & Conh1 & $\begin{array}{l}\text { A faculdade é aberta às ideias e sugestões dos alunos para melhoria } \\
\text { dos cursos existentes }\end{array}$ \\
\cline { 2 - 3 } Conhecimento & Conh2 & $\begin{array}{l}\text { A faculdade é aberta às ideias e sugestões dos alunos para criação de } \\
\text { novos cursos/turmas }\end{array}$ \\
\cline { 2 - 3 } & Conh3 & $\begin{array}{l}\text { A faculdade fornece informações suficientes para o bom andamento } \\
\text { do curso }\end{array}$ \\
\cline { 2 - 3 } & Conh4 & $\begin{array}{l}\text { Eu gastaria tempo e esforço para compartilhar com a faculdade } \\
\text { minhas ideias e sugestões }\end{array}$ \\
\cline { 2 - 3 } & Conh5 & $\begin{array}{l}\text { A faculdade fornece ambiente favorável para que eu possa expressar } \\
\text { minhas opiniões e sugestões }\end{array}$ \\
\hline
\end{tabular}




\begin{tabular}{|c|c|c|}
\hline Dimensão & Item & Pergunta/Frase \\
\hline \multirow{5}{*}{ Transparência } & Transp1 & A faculdade busca saber minhas preferências \\
\hline & Transp 2 & $\begin{array}{l}\text { A missão e os valores da faculdade estão em linha com os meus } \\
\text { valores }\end{array}$ \\
\hline & Transp3 & $\begin{array}{l}\text { A faculdade considera que os alunos exercem um papel tão } \\
\text { importante quanto o dela para andamento do curso }\end{array}$ \\
\hline & Transp4 & $\begin{array}{l}\text { O papel do aluno e o da faculdade são igualmente importantes para a } \\
\text { formação do aluno }\end{array}$ \\
\hline & Transp5 & $\begin{array}{l}\text { O nome da faculdade abre portas no mercado de trabalho } \\
\text { independente do desempenho do aluno no curso }\end{array}$ \\
\hline \multirow{4}{*}{ Interação } & Inter 1 & $\begin{array}{l}\text { Durante o curso é permitido que os alunos expressem suas } \\
\text { necessidades individuais }\end{array}$ \\
\hline & Inter2 & $\begin{array}{l}\text { A faculdade transmite aos alunos informações relevantes acerca do } \\
\text { processo de ensino a distância }\end{array}$ \\
\hline & Inter3 & $\begin{array}{l}\text { A faculdade permite a completa interação dos alunos com a } \\
\text { instituição }\end{array}$ \\
\hline & Inter4 & $\begin{array}{l}\text { Espera-se que os alunos sejam proativos na interação com a } \\
\text { faculdade }\end{array}$ \\
\hline \multirow{4}{*}{ Experiência } & Exp1 & $\begin{array}{l}\text { As experiências vividas no curso ficarão em minha lembrança por um } \\
\text { longo tempo }\end{array}$ \\
\hline & Exp2 & As experiências e seus resultados são diferentes dependendo do aluno \\
\hline & Exp3 & $\begin{array}{l}\text { Os alunos têm a oportunidade da experimentação e da prática para } \\
\text { ampliar seu conhecimento }\end{array}$ \\
\hline & Exp4 & $\begin{array}{l}\text { A faculdade fornece boas experiências, além do benefício de se obter } \\
\text { o diploma }\end{array}$ \\
\hline \multirow{3}{*}{ Personalização } & Person1 & $\begin{array}{l}\text { Os benefícios do curso dependem do estudante e de seu envolvimento } \\
\text { nas atividades sugeridas pela faculdade }\end{array}$ \\
\hline & Person2 & A faculdade atende às necessidades individuais de cada aluno \\
\hline & Person3 & $\begin{array}{l}\text { As necessidades individuais dos alunos são decisivas no grau de } \\
\text { envolvimento com a faculdade }\end{array}$ \\
\hline \multirow{8}{*}{ Relacionamento } & Relac1 & Mantenho relacionamento com colegas além das aulas presenciais \\
\hline & Relac2 & A faculdade prepara para desafios do mercado de trabalho \\
\hline & Relac3 & $\begin{array}{l}\text { A faculdade dispõe de infraestrutura física que permite ao aluno } \\
\text { desfrutar completamente da vida universitária }\end{array}$ \\
\hline & Relac4 & Tenho um relacionamento próximo com a faculdade \\
\hline & Relac5 & $\begin{array}{l}\text { A faculdade possui bom desempenho em avaliações do governo } \\
\text { (ENADE, CAPES) }\end{array}$ \\
\hline & Relac6 & $\begin{array}{l}\text { Os alunos escrevem positivamente sobre a faculdade em redes } \\
\text { sociais/mídia }\end{array}$ \\
\hline & Relac7 & Minha família e amigos consideram a faculdade boa \\
\hline & Relac8 & $\begin{array}{l}\text { A faculdade dispõe de atendimento para apoio aos problemas } \\
\text { técnicos ou administrativos dos alunos }\end{array}$ \\
\hline
\end{tabular}

Nota. Elaborado pela autora

Em seu estudo, Ranjan e Read (2016) entendem que o construto cocriação de valor deve ser encarado como um índice, sendo, portanto, composto por indicadores - e variáveis latentes de primeira e segunda ordens - formativos, como indicado na Figura 5, da Seção 3.2. Apesar de os autores defenderem o modelo formativo, o presente estudo considera que 
este modelo deve ser encarado com abordagem reflexivo-formativa, onde os construtos de primeira ordem são reflexivos e os das ordens superiores, formativos (Hair Jr, Hult, Ringle \& Sarstedt, 2017, pp. 282); o que é um aparente detalhe, interfere na análise dos dados, que deve ser realizada de forma distinta, implicando alterações nos resultados finais (Jarvis et al., 2003).

Jarvis et al. (2003) discutem as diferenças e implicações de modelos reflexivos e formativos, apresentando regras de decisão resumidas para a definição de cada um, como indicado na Tabela 10. Comparando os critérios apresentados com os itens dispostos na Tabela 6, tem-se que os construtos de primeira ordem seguem os critérios do modelo reflexivo, com possibilidade de intercâmbio entre indicadores, expectativa de correlação entre indicadores que compõem os construtos, manifestação dos construtos por meio dos indicadores e todos os indicadores refletem aspecto único dentro de um construto.

Tabela 10

Critérios para definição de modelo formativo e modelo reflexivo

\begin{tabular}{|c|c|c|c|}
\hline Critérios & Decisão & Formativo & Reflexivo \\
\hline \multirow{4}{*}{$\begin{array}{c}\text { Direção da } \\
\text { causalidade e } \\
\text { manifestação }\end{array}$} & Qual a direção da causalidade? & Item $->$ Construto & Construto -> Item \\
\hline & $\begin{array}{l}\text { Os Itens definem características do } \\
\text { construto? }\end{array}$ & Sim & Não \\
\hline & $\begin{array}{l}\text { Mudanças nos Itens causam mudanças } \\
\text { no construto? }\end{array}$ & Sim & Não \\
\hline & $\begin{array}{l}\text { Mudanças no construto causam } \\
\text { mudanças no item? }\end{array}$ & Não & Sim \\
\hline \multirow{3}{*}{$\begin{array}{l}\text { Intercâmbio e } \\
\text { Unicidade }\end{array}$} & Os indicadores são intercambiáveis? & Não & Sim \\
\hline & $\begin{array}{l}\text { Os indicadores compartilham o mesmo } \\
\text { tema/conteúdo? }\end{array}$ & Não & Sim \\
\hline & $\begin{array}{l}\text { Retirar um indicador altera o conceito } \\
\text { principal do construto? }\end{array}$ & Sim & Não \\
\hline \multirow[b]{2}{*}{ Covariâncias } & $\begin{array}{c}\text { É esperado que haja covariância entre } \\
\text { os indicadores? }\end{array}$ & Não & Sim \\
\hline & $\begin{array}{l}\text { Quando há uma mudança em um } \\
\text { indicador, é provável que haja nos } \\
\text { demais? }\end{array}$ & Não & Sim \\
\hline $\begin{array}{l}\text { Relação Item- } \\
\text { Construto }\end{array}$ & $\begin{array}{l}\text { Espera-se que os indicadores tenham os } \\
\text { mesmos antecedentes e consequentes? }\end{array}$ & Não & Sim \\
\hline
\end{tabular}

Nota. Adaptado de Jarvis et al., 2003, p. 203 
Após discussão sobre diferenças entre os modelos formativos e reflexivos, a Figura 8 contempla, de forma esquemática, um resumo do modelo de mensuração da cocriação de valor, englobando os itens apresentados na Tabela 9.

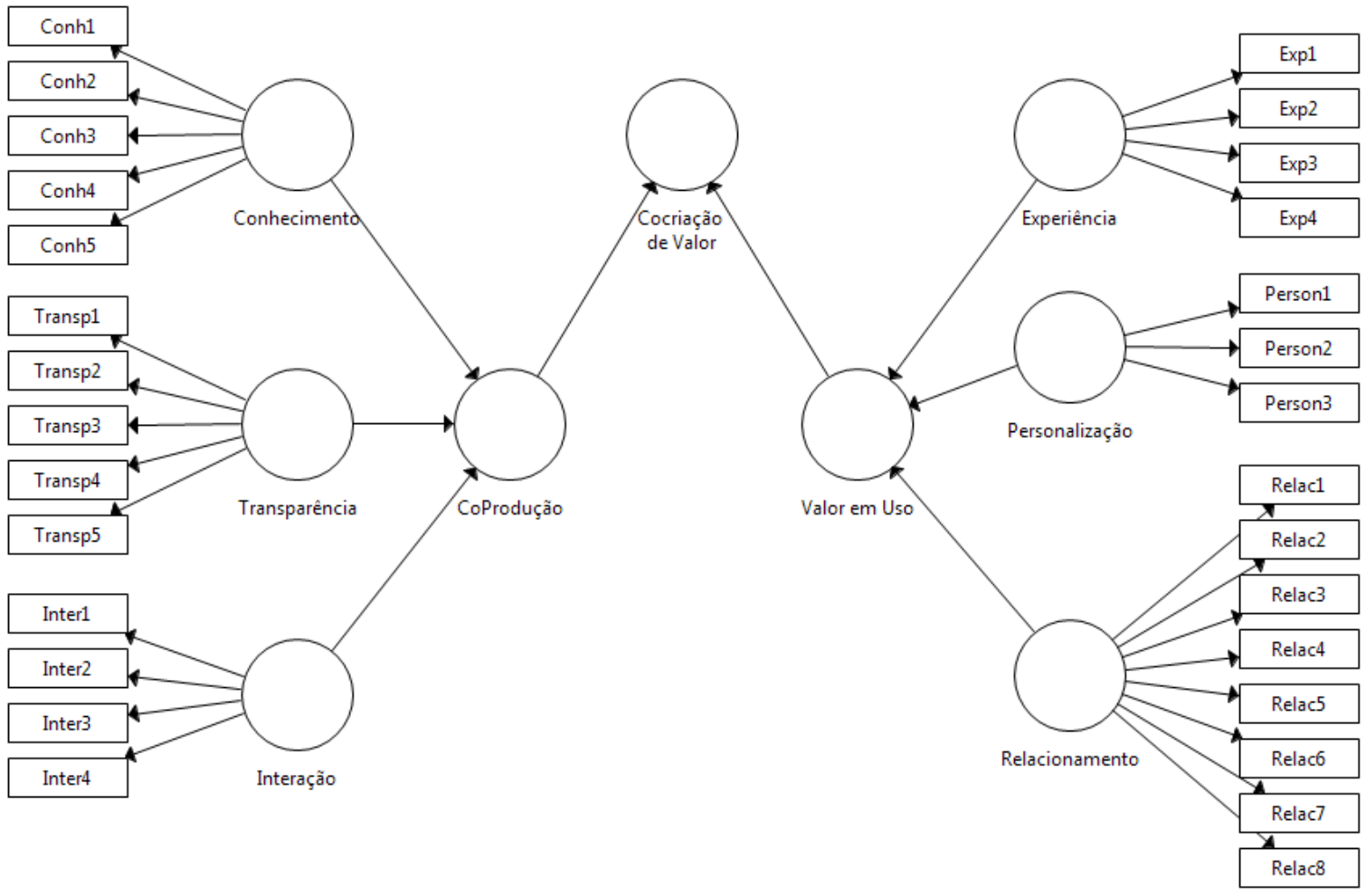

Figura 8. Cocriação de valor: modelo de mensuração (reflexivo-formativo)

Além dos construtos já descritos, solicitou-se que os alunos manifestassem sua opinião a respeito das dimensões Comprometimento e Imagem, que serão abordadas na fase de processamento de um modelo alternativo ao modelo teórico proposto. Na Seção 6.4 estão detalhados os indicadores que compõem cada um destes construtos.

Uma vez delimitado o modelo e indicada a operacionalização de todas as dimensões, o próximo capítulo apresenta os aspectos metodológicos para que seja possível mensurar todas as relações no âmbito da educação a distância, detalhando tipos de pesquisa utilizados, amostragem e instrumentos de coleta dos dados. 


\section{ASPECTOS METODOLÓGICOS}

Neste capítulo estão descritos os aspectos metodológicos utilizados neste trabalho para suportar os objetivos dispostos na Seção 1.1, destacando a tipologia da pesquisa e a população a ser analisada, além de técnicas de coleta e forma de abordagem empregadas.

Segundo Gil (2002), a execução de um projeto de pesquisa deve seguir uma série de fases para melhor organização e obtenção do resultado. Embora cada etapa do projeto deva ser adaptada ao estudo conforme decisão do pesquisador, Gil (2002) esquematiza os dez principais passos para a execução da pesquisa, como mostra a Figura 9.

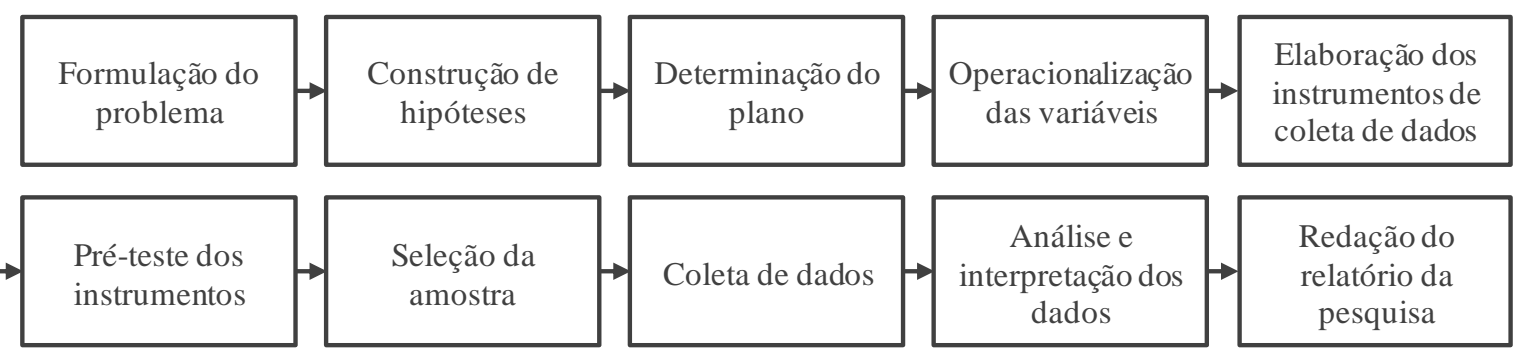

Figura 9. Diagramação da pesquisa. Adaptado pela autora de Gil, 2002, p. 21

Seguindo a diagramação da Figura 9, uma vez que estão definidos o problema, os objetivos e as hipóteses - apontados anteriormente -, passa-se às fases seguintes, de determinação do plano de pesquisa, elaboração do instrumento de coleta e amostra. Neste contexto, deve-se classificar a pesquisa a ser adotada, a forma de coleta dos dados (instrumento e abordagem), a população que se pretende estudar - e a amostragem necessária - e, por fim, destacar os cuidados a serem tomados para minimização de erros não amostrais. São estes os pontos a serem explorados nas próximas seções deste capítulo. 


\subsection{Tipologia de Pesquisa}

Com relação ao tipo de pesquisa, Gil (2002) apresenta três grandes grupos de classificação: pesquisas exploratórias, descritivas e explicativas. A primeira tem como objetivo "proporcionar maior familiaridade com o problema, com vistas a torná-lo mais explícito ou a construir hipóteses" (Gil, 2002, p. 41); a segunda busca a "descrição das características de determinada população ou fenômeno ou, então, o estabelecimento de relações entre variáveis" (Gil, 2002, p. 42) e a última procura "identificar os fatores que determinam ou que contribuem para a ocorrência dos fenômenos" (Gil, 2002, p.42).

Dadas a natureza do problema de pesquisa proposto e as informações atuais disponíveis acerca deste problema, este trabalho foi composto por uma pesquisa exploratória qualitativa - seguida de uma pesquisa descritiva - quantitativa. Barton e Lazarsfeld (1955) sugerem o uso da abordagem qualitativa para o desenvolvimento de hipóteses, seguida de uma abordagem quantitativa, onde serão testadas as hipóteses levantadas. Utilizar os dois tratamentos para obtenção de um resultado final é, também, indicado por outros pesquisadores, como Creswell (1994) e Flick (2009).

Conforme apontado na Seção 4.1, a pesquisa exploratória foi utilizada para compilação de atributos de cada um dos elementos que compõem a cocriação de valor em educação a distância, ora validando ora agregando mais conhecimento prático ao levantamento bibliográfico realizado. Foram também levantados aspectos únicos da educação a distância, como cursos com maiores taxas de evasão, formato das aulas - identificando os papéis de professores, tutores e alunos -, entendimento do conceito de polos - e sua diferença em relação aos campi - e percepções sobre as expectativas dos alunos ao ingressarem e em cada fase de um curso de graduação a distância.

Em uma pesquisa de natureza qualitativa, os respondentes são escolhidos de forma a obter as melhores respostas à questão levantada, sem a necessidade de nenhum tipo de aleatorização dos indivíduos (Creswell, 1994). Neste trabalho, a população de interesse para esta etapa da pesquisa referiu-se a coordenadores e/ou responsáveis pelo curso EaD, profissionais que possuem conhecimento sobre o todo, de forma a contribuir tanto com a percepção da universidade (e professores) quanto do aluno. Foram amostrados três 
indivíduos para esta etapa (neste trabalho eles serão chamados de A, B e C por motivos de confidencialidade).

Esta parte da pesquisa envolve maior aprofundamento do tema, o que implica maior tempo despendido individualmente. A abordagem foi pessoal e realizada por meio de entrevista com roteiro planejado, porém, sem um formulário predeterminado (Apêndice A - Roteiro de Pesquisa Qualitativa). Este roteiro englobou questões acerca dos atributos apontados para a cocriação de valor, além das definiçõoes de lealdade, satisfação e qualidade percebida, validando assim, o conteúdo de cada um dos construtos. Considerada por Marconi e Lakatos (2008) uma entrevista não dirigida, ela apresenta a vantagem de permitir que o entrevistado possa expressar suas opiniões e sentimentos livremente, com o entrevistador fazendo papel de incentivador, sem, porém, forçar uma resposta do entrevistado.

Cada um dos entrevistados optou por realizar a entrevista em localização que se sentisse mais confortável para a conversa e lhe foi garantido sigilo de algumas das informações sensíveis à estratégia do negócio, além de sua identidade e a da faculdade/empresa que ele representava. A coleta ocorreu por meio de anotações e gravações das entrevistas realizadas.

Segundo o entrevistado A, ainda há muitos mitos sobre a graduação $\mathrm{EaD}$, especialmente no que tange a qualidade do ensino: "Se, em um primeiro momento, o aluno entende que há a necessidade de um curso superior para melhoria de vida - e o EaD possui custo cerca de $30 \%$ menor do que a graduação presencial -, fica muito entusiasmado ao saber que o seu diploma será idêntico ao do aluno do curso tradicional".

Pragmático, o entrevistado B aponta que o ensino a distância permitiu que pessoas que não poderiam estudar em uma faculdade tradicional - especialmente pelo custo - fossem as primeiras da família a terem curso superior. Segundo este entrevistado, em pesquisa interna realizada em sua faculdade, acima de $80 \%$ dos alunos estão nesta condição. Ele reforça que a ascensão social e a possibilidade de maiores ganhos financeiros no emprego por melhor preparação ao mercado de trabalho cada vez mais exigente são os maiores incentivos do aluno que busca o curso de graduação a distância. 
Já o entrevistado $\mathrm{C}$ indicou o orgulho, tanto do aluno quanto dos indivíduos em sua rede social (virtual ou não, como família e amigos), como sendo de extrema importância para que o aluno inscreva-se e mantenha-se no curso.

Os três entrevistados levantaram que a ideia de flexibilidade que o curso a distância traz e a possibilidade de os alunos manterem contato com os colegas parecem ser fatores a serem considerados na valoração do curso. Com relação à identificação da qualidade, tanto o entrevistado B quanto o $\mathrm{C}$ entendem que é a experiência com o site o que mais influencia: para eles, o aluno espera que o site funcione perfeitamente, que possa contar com apoio [rápido] da faculdade sempre que necessário resolver algum problema e tenha à disposição documentos ou certificados sem a necessidade de comparecer ao polo ou campus.

Foi a partir desta etapa que ficou definida a não distribuição de brindes para incentivo às respostas dos alunos. Segundo o entrevistado B, pesquisas internas mostraram respostas pouco fidedignas quando brindes eram oferecidos.

Algumas perguntas foram incluídas ao questionário após esta etapa qualitativa:

- A faculdade dispõe de atendimento para apoio aos problemas técnicos ou administrativos dos alunos;

- Mantenho relacionamento com colegas além das aulas presenciais;

- A faculdade prepara para desafios do mercado de trabalho;

- Minha família e amigos consideram a faculdade boa.

Uma vez que todas as hipóteses acerca dos componentes da cocriação de valor para a educação a distância estavam claras/validadas por indivíduos externos ao desenvolvimento do estudo, seguiu-se para a pesquisa descritiva - quantitativa. Para esta fase, foi conduzida uma pesquisa do tipo levantamento (ou survey). Conforme destaca Gil (2002), as pesquisas desta natureza caracterizam-se pela abordagem direta das pessoas cujo comportamento se deseja conhecer, interrogando-as sobre o problema estudado para, posteriormente, por meio dos dados quantitativos, obter as conclusões à pergunta levantada. 
As principais vantagens deste método dizem respeito à facilidade, economia e rapidez na obtenção das respostas e quantificação das informações de forma padronizada, sendo possível - desde que com planejamento amostral bem delineado - o uso de técnicas estatísticas que permitam concluir acerca da população estudada.

No caso específico deste trabalho, o interesse era em entender o comportamento e percepções dos estudantes de graduação de cursos da modalidade EaD sobre as relações entre as dimensões de cocriação de valor, qualidade percebida, satisfação e lealdade, sendo, portanto, estes os indivíduos a compor a população-alvo do levantamento.

Para a coleta dos dados foi utilizado um questionário estruturado, com uma série ordenada de perguntas a serem respondidas pelos indivíduos amostrados (o instrumento de coleta de dados utilizado nesta pesquisa está descrito de forma detalhada no Apêndice B).

A abordagem utilizada foi a de questionários autopreenchíveis, com elaboração via plataforma QuestionPro e envio do link de acesso por e-mail aos alunos dos cursos EaD. Os endereços eletrônicos dos alunos foram obtidos por meio de parceria com uma empresa de soluções de marketing com foco em educação superior e faculdades particulares com atuação nacional. Como já mencionado, todas as empresas solicitaram sigilo de seus nomes. As faculdades amostradas foram responsáveis por $59 \%$ das matrículas totais de $\mathrm{EaD}$ em 2015; considerando apenas as faculdades particulares, que foi onde a pesquisa conseguiu maior penetração, este número passa a ser de pouco mais de $64 \%$ das matrículas (INEP, 2016).

Em um questionário, é fundamental para que haja a consistência dos dados, que as questões reflitam o que se deseja obter de resposta e sejam claras para os respondentes. Para que fosse possível avaliar previamente validade (as informações obtidas são necessárias à pesquisa), fidedignidade (as respostas obtidas independem da forma de preenchimento, com ou sem a presença de um entrevistador) e operatividade (vocabulário utilizado é compreensível e claro para os entrevistados) do instrumento de coleta dos dados, foi conduzido um pré-teste, aplicado a uma amostra de cinco estatísticos com experiência entre oito e 25 anos na aplicação de questionários e, posteriormente, a 10 alunos de EaD. Neste momento, foi realizada uma análise sobre cada uma das perguntas 
presentes no questionário, com avaliação sobre o tempo gasto em cada etapa do preenchimento e possíveis falhas na elaboração, como perguntas que influenciassem as respostas seguintes e perguntas supérfluas à pesquisa, além da clareza e melhor ordenação das perguntas (Marconi \& Lakatos, 2008).

Durante o pré-teste foram sugeridas alterações no texto de algumas perguntas originalmente escritas gerando menos dúvidas e maior entendimento do que se queria questionar. Também foi por meio desta etapa que se obteve o tempo total estimado da pesquisa (10 a 15 minutos) e a avaliação sobre as categorias consideradas, especialmente aquelas referentes às áreas dos cursos.

Ao final, o questionário foi mostrado para os entrevistados da etapa qualitativa, a quem foi perguntado se sentiam que todas as questões levantadas estavam incorporadas no instrumento; não houve novas sugestões com exceção da mudança da pergunta "A faculdade fornece boas experiências, além do benefício de se obter o diploma" para o construto Experiência ao invés do original Personalização. Novo exame no estudo de Ranjan e Read (2016) sobre este item especificamente indicou que houve divergência entre os dois entrevistados que classificaram este elemento, com um deles apontando para Personalização e outro, para Experiência. Tendo havido um consenso entre os participantes da pesquisa qualitativa realizada no presente estudo sobre a alocação desta pergunta no construto de Experiência, foi feita a alteração - como pode ser constatado na Tabela 9 - e se considerou que o conteúdo estava validado.

A validade de conteúdo realizada com indivíduos externos à pesquisa torna-se importante para que haja isenção na avaliação. Esta etapa, apesar de ter aparente simplicidade, é de extrema importância para que realmente as perguntas realizadas de fato façam sentido ao que se deseja medir (Tull \& Hawkins, 1984; DeVellis, 2012).

Após o pré-teste e a validação realizada com os responsáveis e coordenadores, o questionário estava pronto (Apêndice $\mathrm{B}$ ) para ser disponibilizado à amostra para o preenchimento, de forma a ser possível realizar a análise proposta pelo estudo. 
A próxima seção detalha o instrumento de pesquisa utilizado, descrevendo a ordenação das perguntas, tipos de escala utilizados e discussão sobre o uso de questionários online.

\subsection{Instrumento de Coleta dos Dados}

Com as perguntas a serem realizadas definidas, a próxima etapa refere-se à confecção do instrumento de coleta utilizado. Para descrever os construtos qualidade percebida, satisfação e lealdade, Mantovani (2012) lançou mão de variáveis encontradas na literatura ou adaptadas de pesquisadores, medindo-as por meio de escala Likert de 5 pontos, onde os respondentes deviam apontar seu grau de concordância segundo 1 = discorda totalmente; 2 $=$ discorda em parte; 3 = não concorda nem discorda; $4=$ concorda em parte e $5=$ concorda totalmente.

Apesar do amplo uso de escala Likert (de 5, 6 ou 7 pontos) em estudos da área de EaD como apontado por Mantovani (2012), decidiu-se pela utilização de escala de 10 pontos para a abordagem das perguntas referentes aos construtos do modelo proposto, com indicativo sobre os valores que se referiam a cada grau de concordância, de forma a homogeneizar o entendimento das respostas. A escolha por esta escala ocorreu em função do número total de perguntas, sendo de fácil assimilação aos estudantes, diminuindo, assim, a fadiga nas respostas e aumentando comprometimento para ir até o fim do questionário. Era solicitado ao respondente que desse uma nota de 1 a 10 para cada uma das afirmações, conforme o grau de concordância, considerando, como referência:

- Baixa concordância: 1 a 4

- Média concordância: 5 e 6

- Alta concordância: 7 a 10

A coleta de dados ocorreu por meio de questionário disponibilizado de forma online, na plataforma QuestionPro. Conforme destacado por Alreck e Settle (1995), a confecção do instrumento de coleta dos dados deve seguir algumas normas. As questões devem 
apresentar as características de foco, brevidade e clareza. O uso de vocabulário e gramática corretos também é fundamental.

Alreck e Settle (1995) destacam, ainda, a necessidade de minimização de erros ou vieses por meio de ordenação de perguntas, especificidade ou não aplicabilidade das questões a todos da amostra, ambiguidade, perguntas direcionadas entre outros. Nesta pesquisa, em que os alunos avaliaram pontos a respeito da universidade, é importante ressaltar o cuidado tomado para que as perguntas não fossem do tipo que induzissem a determinadas respostas apenas por prestígio, status ou por parecer ser aquela a resposta correta - pontos alinhados no pré-teste.

Com relação às questões, elas podem ser estruturadas (fechadas) ou não estruturadas (abertas). As primeiras apresentam vantagens de padronização dos resultados, além de rapidez nas respostas e posterior tabulação - e análise - dos dados. Já a segunda permite que o pesquisador avalie a pergunta sem a restrição de analisar quais seriam as respostas possíveis ou fique limitado a um número de categorias preestabelecido; Alreck e Settle (1995) recomendam o uso de, no máximo, seis ou oito categorias nas perguntas fechadas. Neste trabalho, decidiu-se pela utilização apenas de perguntas fechadas, com a solicitação de respostas não estruturadas nos casos em que as categorias existentes não contemplavam a situação do aluno respondente.

O questionário, especialmente o autopreenchível, deve apresentar uma introdução que transmita a razão pela qual é necessária a participação de forma séria do entrevistado sem, contudo, direcionar as respostas do indivíduo. Em seguida, inicia-se o corpo da pesquisa. É nesta parte que são alocados os filtros da pesquisa, que impedem que respondentes que não fizessem parte do escopo do estudo permanecessem na amostra final, além de conter as perguntas mais genéricas, de fácil resposta. As próximas etapas devem conter as demais perguntas, agrupando-as em seções similares. A finalização do questionário ocorre com perguntas de cunho demográfico. A razão para esta ordenação se deve ao fato de que, no início, o respondente está mais comprometido e atento com as respostas (Alreck \& Settle, 1995). 
Conforme destacado por Wright (2005), o uso de questionários online apresenta vantagens e desvantagens, que devem ser consideradas no estudo. As principais vantagens referem-se à facilidade de acesso às pessoas, ganho de tempo na tabulação dos dados e custo de pesquisa. Quando observadas as desvantagens, Couper (2000) aponta principalmente a falta de controle da amostra e erros de medida, em geral por desestímulo do respondente às questões levantadas, o que pode ocasionar desistências ou respostas realizadas sem a devida atenção. Para minimizar estas situações, a escala utilizada foi uma de fácil assimilação aos respondentes, além da alocação de pergunta de controle solicitando que o respondente desse uma nota geral ao curso. Alunos com baixa consistência entre a nota geral e demais notas dadas foram excluídos da amostra. Além disso, para que fosse controlada a coerência nas respostas, foram excluídos alunos com respostas muito discrepantes dos demais (outliers multivariados) e/ou com todas as respostas em uma mesma nota. O índice de desistência manteve-se próximo a 50\% do total de indivíduos que iniciou a pesquisa. No próximo capítulo, que trata de resultados da análise, será mais bem detalhada esta etapa.

Couper (2000) cita, ainda, o nível de acesso à Internet da população em geral (ponto de pouca relevância neste trabalho, uma vez que os estudantes devem ter familiaridade com o meio online e acesso à Internet para realizar o curso).

Seguindo todas as recomendações, foi composto o questionário com o seguinte bloco de perguntas:

- filtro e/ou relativas ao curso;

- frases referentes aos construtos a serem analisados para avaliação de concordância - aleatorizadas para minimização de viés de resposta;

- dados demográficos.

O questionário completo pode ser encontrado no Apêndice B. Em letras maiúsculas estão comentários que não eram vistos pelos respondentes, escritos para demarcar regras a serem conduzidas ao longo do processo, dependendo da resposta dada.

Detalhes sobre frases não explicitadas até então serão descritos ao longo do Capítulo 6. 
Com o instrumento de coleta bem definido, a próxima etapa é limitar quem deve ser o indivíduo amostrado - e qual amostra considerar. É sobre este ponto que se desenvolve a próxima seção.

\subsection{Amostragem}

Para a realização deste trabalho, foram realizados contatos com representantes de três faculdades que possuem cursos na modalidade $\mathrm{EaD}$, além de empresa de marketing voltada ao mercado de Educação. Juntas, as faculdades atingidas por estas empresas possuem mais de $64 \%$ do total de matrículas de graduação [privada] a distância do Brasil.

Conforme já relatado, na etapa quantitativa, foram enviados e-mails a uma amostra de alunos por duas fontes distintas: empresa de marketing voltada à educação (todos os alunos cadastrados na base de dados, de faculdades, cursos e áreas distintas) e de faculdades que forneceram lista de alunos de cursos previamente selecionados, abrangendo características como área de estudo (exatas/humanas/biológicas), ciclo do aluno (calouro/regular/ formado) e região do país. O tipo de amostra neste caso é a amostragem aleatória estratificada. Nesta tipologia, a população total é dividida em subpopulações de interesse não interseccionadas e de tamanhos conhecidos -, às quais se dão o nome de estrato. Em seguida, para cada estrato retira-se uma amostra aleatória simples (Cochran, 1977). Conforme destaca Gil (2002), a principal vantagem é o fato de garantir representatividade dos grupos de interesse de análise. A opção pela estratificação apontada ocorreu para a obtenção dos resultados sob a ótica de alunos diversos, minimizando resultados em função de regionalidade ou área do conhecimento.

O tamanho da amostra necessário para a obtenção dos resultados foi obtido utilizando o software G*Power 3.1.9.2 (Faul, Erdfelder, Lang \& Buchner, 2007), que avalia o número mínimo de casos segundo características pré-definidas (Hair et al., 2017). Considerando que, no modelo, o máximo de setas apontando para um mesmo preditor é cinco (qualidade percebida) e utilizando efeito médio $\left(\mathrm{f}^{2}=0,15\right)$, poder do teste de $80 \%$ e significância de 5\%, a amostra deve ser de 92 casos. Mantendo demais indicadores fixos e variando o poder 
do teste para 95\%, tem-se que a amostra necessária é de 138 casos. Assim, uma amostra entre 92 e 138 indivíduos torna-se adequada.

O total de nomes disponibilizados pelas faculdades foi de 20.000 e, pela empresa de marketing educacional, 16.573. As listas foram comparadas, sendo excluídos os e-mails com mais de uma ocorrência. Foram, também, corrigidos e-mails com claros erros de digitação, como aqueles com espaçamento entre letras (foi retirado o espaço) ou com nomes de provedores errados (por exemplo, gmial foi substituído por gmail) e com partes faltantes (como .com ou .com.br). Aqueles que não foram passíveis de correção foram descartados. Ao final, foi enviado o convite de participação com o link para o questionário online a 31.632 pessoas.

O período de coleta dos dados ocorreu entre outubro de 2016 e dezembro de 2016. Sem uma política de incentivo por meio de brindes, englobando período de final de ano letivo e festas, era esperado baixo índice de retorno. No total, 1.475 pessoas abriram o e-mail enviado e 1.091 clicaram no link e iniciaram a pesquisa. Destes, 562 indivíduos responderam até o final (retorno de 1,78\%). O tempo médio de resposta foi de 11 minutos.

O próximo capítulo apresenta os resultados da análise dos dados obtidos. 


\section{ANÁLISE DOS RESULTADOS}

A análise dos resultados foi dividida em três etapas: na primeira, foi realizado tratamento dos dados, com retirada de casos que, por algum motivo, não eram condizentes com a análise. A segunda etapa foi a de análise descritiva, com o perfil dos respondentes e suas respostas. A última corresponde aos resultados dos modelos de mensuração e estrutural, tanto para a visão global dos dados (todos os respondentes) quanto para avaliação por características específicas, conforme objetivo (e) descrito na Seção 1.1.

Durante todo o processo de análise dos dados, foram utilizados os softwares Microsoft Excel 2007, IBM SPSS versão 20 e SmartPLS 3.2.6.

\subsection{Tratamento dos Dados}

Conforme descrito na Seção 5.3, houve a resposta completa de 562 alunos. Para garantir que os respondentes estivessem dentro do perfil desejado da pesquisa, foram feitas três exigências - filtros - durante o questionário (Apêndice B):

- os respondentes deveriam declarar serem ou já terem sido alunos de algum curso de graduação a distância, excluindo, desta forma, alunos de cursos de idiomas, pós-graduação ou educação continuada da modalidade EaD, por exemplo;

- o aluno deveria estar com a matrícula em dia (cursando), ter trancado ou cancelado o curso ou ter se formado. Quaisquer outras situações tornavam o aluno inapto a participar da pesquisa;

- os cursos de graduação deveriam ser da tipologia bacharelado, licenciatura ou tecnólogo. Assim, alunos de cursos de especialização ou específicos não deveriam fazer parte da amostra.

Com estes filtros, foram excluídos 142 respondentes - resultando em 420 casos. 
Em seguida, as respostas às frases de concordância foram avaliadas, sendo retirados da amostra indivíduos com respostas idênticas em todas as perguntas, além de alunos com respostas fora do padrão esperado (outliers multivariados), utilizando como critério, a distância de Mahalanobis (Hair et al., 2006). Esta técnica possibilita calcular as distâncias entre cada um dos pontos a um ponto central considerando o conjunto de todas as observações, de forma multivariada. Para que seja possível estabelecer um critério de detecção dos outliers baseado nesta distância, lança-se mão do fato de este valor, dividido pelo número de variáveis envolvidas no cálculo, possuir uma distribuição t-Student; logo, tem-se a determinação do valor máximo aceitável para os dados fazendo a comparação com a curva da distribuição; Hair et al. (2006) sugerem a adoção de valores baixos de significância na detecção de outliers $-\mathrm{o}$ valor adotado foi $\mathrm{p}=0,001$ para identificação de casos discrepantes. Após os dois processos - respostas todas iguais e oultiers -, 20 casos foram descartados.

Uma vez que o questionário foi realizado de forma online, com a necessidade de preenchimento de todos os itens para prosseguimento, não houve casos faltantes (missing) na amostra.

Após todo o tratamento dos dados, restaram 400 casos para que fosse desenvolvida a análise dos dados. Comparando com a amostra necessária apontada no final do Capítulo 5, pode-se dizer que ela é suficiente para a análise com a visão global dos dados, podendo dar seguimento ao perfil e posterior modelos de mensuração e estrutural.

\subsection{Perfil da Amostra}

A amostra final foi composta por 400 respondentes, sendo 208 (52\%) mulheres e 192 (48\%) homens. Com relação à faixa etária, grande parte dos alunos declarou ter até 29 anos (47,1\%), com 5,5\% dizendo ter 50 anos ou mais; adultos jovens e maduros (30 a 49 anos) representam os demais 47,4\%. A Tabela 11 apresenta as distribuições dos dados demográficos obtidas na pesquisa. 
Indivíduos casados ou em união estável representaram 51,5\% da amostra, enquanto solteiros foram 41,9\%. Alunos com as demais situações maritais somaram 26 casos $(6,6 \%)$. Outra pergunta realizada no questionário foi se os respondentes tinham filhos ou não e, em caso positivo, a idade do mais novo. Pouco mais da metade da amostra (201 casos) afirmou possuir pelo menos 1 filho. Dentre estes, 39,8\% tinham filhos pequenos, ainda em idade pré-alfabetização (até 5 anos), outros 39,8\% tinham, como filhos caçulas, crianças e adolescentes (entre 6 e 15 anos), $8 \%$ tinham filhos com idade entre 16 e 18 anos e os filhos dos demais 12,4\% tinham 19 anos ou mais. Estas perguntas foram levantadas para entendimento da disponibilidade de tempo para o curso, uma vez que, conforme discutido no Capítulo 2, é de consenso geral que a educação a distância proporciona maior flexibilidade ao aluno.

Por fim, a última pergunta do questionário foi como era a situação empregatícia do aluno. Uma taxa de 76,3\% afirmou ter trabalho remunerado - incluindo os autônomos nesta contagem - enquanto que 18,3\% afirmaram estar desempregados (sem trabalho, mas procurando). Na economia brasileira, segundo dado divulgado pelo IBGE em sua Pesquisa Nacional por Amostra de Domicílios Contínua - Mensal (PNAD Contínua), a taxa de desocupação era de $12 \%$ no trimestre outubro-novembro-dezembro (IBGE, 2017) - alta, mas menor do que a encontrada na amostra - permitindo a reflexão acerca do motivo de matrícula em curso online (melhoria de posição ou busca por trabalho) quando o aluno se inscreve em um curso de graduação a distância, conforme levantado na fase qualitativa da pesquisa. 
Tabela 11

Perfil demográfico da amostra

\begin{tabular}{lr}
\hline \multicolumn{1}{c}{ Características Demográficas } & Amostra \\
\hline Gênero & \\
Feminino & $52,0 \%$ \\
Masculino & $48,0 \%$ \\
& \\
Faixa Etária & \\
Até 16 anos & $0,0 \%$ \\
17 a 24 anos & $26,8 \%$ \\
25 a 29 anos & $20,3 \%$ \\
30 a 34 anos & $17,8 \%$ \\
35 a 39 anos & $15,3 \%$ \\
40 a 49 anos & $14,3 \%$ \\
A partir de 50 anos & $5,5 \%$ \\
& \\
Status Marital & \\
Solteiro(a) & $41,9 \%$ \\
Casado(a)/União Estável & $51,5 \%$ \\
Separado(a)/Divorciado(a) & $4,8 \%$ \\
Outro & $1,8 \%$
\end{tabular}

Filhos

\begin{tabular}{lr} 
Não & $49,7 \%$ \\
Sim & $50,3 \%$ \\
\hline Até 2 anos & $14,4 \%$ \\
Entre 2 e 5 anos & $25,4 \%$ \\
Entre 6 e 15 anos & $39,8 \%$ \\
Entre 16 e 18 anos & $8,0 \%$ \\
A partir de 19 anos & $12,4 \%$
\end{tabular}

Situação de Trabalho

Remunerado/Autônomo 76,3\%

No lar $\quad 3,0 \%$

Desempregado $18,3 \%$

Outros $2,4 \%$

Nota. Elaborado pela autora a partir dos dados da amostra. $\mathrm{N}=400$

Com relação ao curso de graduação EaD em si e o ciclo do aluno, é possível observar, por meio da Tabela 12, que são 361 (90,2\%) indivíduos os que disseram serem alunos, 22 $(5,5 \%)$ estão com matrículas canceladas ou trancadas e 17 (4,3\%) formaram-se em uma graduação deste tipo. Dentre os formados, 29,4\% estão formados há menos de 1 ano, $58,8 \%$ entre 1 e 5 anos e 11,8\%, formaram-se há mais de 5 anos. Para a maior parte 
$(59,1 \%)$ dos alunos em situação de cancelamento ou trancamento, a matrícula encontra-se neste status há menos de 3 meses.

\section{Tabela 12}

Perfil da amostra referente à situação estudantil

\begin{tabular}{lr}
\hline Características - Situação Estudantil & Amostra \\
\hline Situação de Matrícula & $90,2 \%$ \\
Ativa & $40,7 \%$ \\
\hline lo semestre & $22,7 \%$ \\
2o semestre & $11,6 \%$ \\
2o ano & $12,5 \%$ \\
3o ano & $12,5 \%$ \\
4o ou 5o anos & $4,3 \%$ \\
Trancada ou cancelada & $59,1 \%$ \\
\hline Há menos de 3 meses & $40,9 \%$ \\
Há mais de 3 meses & $5,5 \%$ \\
Aluno formado & $29,4 \%$ \\
Há menos de 1 ano & $58,8 \%$ \\
Entre 1 e 5 anos & $11,8 \%$ \\
Há mais de 5 anos & \\
Localização do Polo & $26,7 \%$ \\
Capital & $73,3 \%$ \\
Interior & \\
Região Geográfica do Polo & \\
Nordeste & $15,7 \%$ \\
Sudeste & $19,0 \%$ \\
Outros & $65,3 \%$ \\
Tipologia do Curso & \\
Bacharelado & $23,5 \%$ \\
Licenciatura & $51,0 \%$ \\
Tecnólogo & continua)
\end{tabular}




\begin{tabular}{lr}
\hline Características - Situação Estudantil & Amostra \\
\hline Área do Curso & \\
Biológicas/Saúde & $17,5 \%$ \\
\hline Educação Física & $64,3 \%$ \\
Biologia/Ciências Biológicas & $21,4 \%$ \\
Estética/Imagem Pessoal/Embelezamento & $10,0 \%$ \\
Outros & $4,3 \%$ \\
Exatas & \\
\hline Desenvolvimento e Análise de Sistemas & $28,8 \%$ \\
Matemática & $47,0 \%$ \\
Engenharias & $31,3 \%$ \\
Outros & $18,3 \%$ \\
& $3,5 \%$ \\
Humanas & \\
\hline Pedagogia & $53,7 \%$ \\
Administração & $24,2 \%$ \\
Ciências Contábeis/Contabilidade & $16,3 \%$ \\
Outros & $9,8 \%$ \\
\hline Nota. Elaborado pela autora a partir dos dados da amostra N N & $49,7 \%$ \\
\hline
\end{tabular}

Nota. Elaborado pela autora a partir dos dados da amostra. $\mathrm{N}=400$

Primeiro-anistas foram os maiores respondentes da pesquisa: 40,7\% dos estudantes com vínculo ativo na faculdade são do $1^{\circ}$ semestre e $22,7 \%$ são do segundo semestre, totalizando $63,4 \%$ da amostra obtida. Os alunos restantes dividem-se de forma similar entre os demais anos: $11,6 \%$ estão no $2^{\circ}$ ano, $12,5 \%$ estão no $3^{\circ}$ ano e $12,5 \%$ estão no $4^{\circ}$ ou $5^{\circ}$ ano (últimos anos para os cursos avaliados).

Conforme apontado no Capítulo 2, a graduação EaD teve início com o objetivo de ampliar e interiorizar a oferta de cursos e programas de educação superior. No mesmo capítulo discutiu-se a distribuição geográfica dos alunos, com alta participação de cidades do interior do país. O mesmo é verificado na amostra da pesquisa: 293 (73,3\%) alunos afirmaram que seus polos estavam localizados em cidades interioranas. Com relação à região do país, a penetração da pesquisa foi ligeiramente menor do que o obtido no censo para as regiões Nordeste e Sudeste, possivelmente em função do baixo volume de alunos de faculdades públicas na pesquisa, que estão representadas nas matrículas do censo da educação superior - e maior penetração nas demais regiões; Sul, Norte e Centro-Oeste equivaleram a $65,3 \%$ dos respondentes da pesquisa - versus $39 \%$ encontrados no Censo. 
Em linha com o esperado, a maior parte dos alunos era do curso de licenciatura (51\%), com bacharelado representando $23,5 \%$. Os demais eram alunos de graduação do tipo tecnólogo. A área de Humanas apresentou destaque entre os alunos - 53,7\% deles estavam em cursos desta natureza, sendo Pedagogia (com 52 alunos), Administração (com 35) e Ciências Contábeis/Contabilidade (com 21) os cursos com mais inscritos. A segunda área do conhecimento mais relevante foi Exatas, contando com 28,8\% dos respondentes, que se dividiam em basicamente três cursos (na ordem de alunos matriculados): Desenvolvimento e Análise de Sistemas (com 54 alunos), Matemática (com 36) e Engenharia (com 21). Dentre os estudantes de Biológicas (17,5\% do total), 45 eram de Educação Física, 15 de Biologia/Ciências Biológicas; os 10 demais alunos desta área fazem Estética/Imagem Pessoal/Embelezamento (7), Enfermagem (2) e Ciências Naturais (1).

Com um panorama geral - demográfico e estudantil - dos respondentes da pesquisa, podese examinar quais as suas avaliações perante as frases que compõem cada uma das dimensões presentes no modelo proposto. A Tabela 13 sumariza estes resultados por meio de análise descritiva dos dados: médias, medianas, desvios padrões, coeficientes de variação, assimetria e curtose dos itens (Bussab \& Morettin, 2013). Observando os coeficientes de variação (em sua maioria, acima de 30\%), verifica-se grande dispersão das respostas; porém, é possível afirmar que, de forma geral, houve maior concordância do que discordância em todos os quesitos, uma vez que os valores de assimetria são negativos e médias e medianas são maiores que 6 . 
Tabela 13

Estatísticas descritivas dos itens dos construtos

\begin{tabular}{|c|c|c|c|c|c|c|c|}
\hline & Construtos e respectivos itens & Med & Média & DP & $\mathrm{CV}$ & Assim & Curt \\
\hline \multirow{4}{*}{ 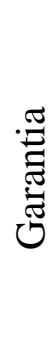 } & Os instrutores conhecem profundamente a sua área & 8,0 & 7,7 & 2,4 & 0,3 & $-1,2$ & 0,7 \\
\hline & $\begin{array}{l}\text { Os instrutores são justos e imparciais ao atribuir notas } \\
\text { aos trabalhos e provas }\end{array}$ & 8,0 & 7,9 & 2,2 & 0,3 & $-1,2$ & 1,1 \\
\hline & $\begin{array}{l}\text { Os instrutores respondem as dúvidas a eles enviadas } \\
\text { de forma completa e cuidadosa }\end{array}$ & 8,0 & 7,7 & 2,4 & 0,3 & $-1,1$ & 0,5 \\
\hline & $\begin{array}{l}\text { Os instrutores conhecem profundamente os materiais } \\
\text { do curso }\end{array}$ & 8,0 & 7,7 & 2,3 & 0,3 & $-1,0$ & 0,6 \\
\hline \multirow{4}{*}{ : } & Os instrutores preocupam-se com os alunos & 8,0 & 7,5 & 2,5 & 0,3 & $-1,0$ & 0,3 \\
\hline & $\begin{array}{l}\text { Os instrutores compreendem as necessidades } \\
\text { individuais dos alunos }\end{array}$ & 8,0 & 7,3 & 2,6 & 0,4 & $-0,8$ & $-0,3$ \\
\hline & $\begin{array}{l}\text { Os instrutores pensam nos interesses de longo prazo } \\
\text { dos alunos }\end{array}$ & 8,0 & 7,4 & 2,5 & 0,3 & $-0,8$ & $-0,1$ \\
\hline & $\begin{array}{l}\text { Os instrutores motivam e estimulam os alunos a darem } \\
\text { o seu melhor no curso }\end{array}$ & 8,0 & 7,7 & 2,5 & 0,3 & $-1,1$ & 0,5 \\
\hline \multirow{4}{*}{ 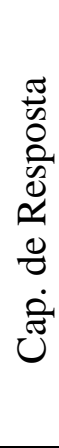 } & $\begin{array}{l}\text { Os instrutores são acessíveis fora dos momentos de } \\
\text { encontro }\end{array}$ & 8,0 & 7,4 & 2,6 & 0,3 & $-1,0$ & 0,1 \\
\hline & $\begin{array}{l}\text { Os instrutores dão retorno às solicitações dos alunos } \\
\text { rapidamente }\end{array}$ & 8,0 & 7,2 & 2,6 & 0,4 & $-0,9$ & $-0,1$ \\
\hline & $\begin{array}{l}\text { Os instrutores fazem tudo o que podem para ajudar os } \\
\text { alunos, mesmo que isso vá além de suas } \\
\text { responsabilidades }\end{array}$ & 8,0 & 7,2 & 2,6 & 0,4 & $-0,8$ & $-0,2$ \\
\hline & $\begin{array}{l}\text { Os instrutores valorizam perguntas e comentários dos } \\
\text { alunos }\end{array}$ & 9,0 & 7,8 & 2,4 & 0,3 & $-1,1$ & 0,4 \\
\hline \multirow{8}{*}{ 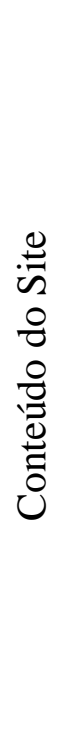 } & $\begin{array}{l}\text { Os recursos de áudio utilizados nos cursos são } \\
\text { apropriados }\end{array}$ & 8,0 & 7,6 & 2,3 & 0,3 & $-1,0$ & 0,6 \\
\hline & $\begin{array}{l}\text { Os recursos de vídeo utilizados nos cursos são } \\
\text { apropriados }\end{array}$ & 8,0 & 7,7 & 2,4 & 0,3 & $-1,2$ & 0,9 \\
\hline & $\begin{array}{l}\text { O curso utiliza adequadamente ferramentas } \\
\text { multimídia (áudio, vídeo, animações, gráficos) }\end{array}$ & 8,0 & 7,8 & 2,4 & 0,3 & $-1,2$ & 0,8 \\
\hline & O ambiente virtual apresenta informações confiáveis & 9,0 & 8,1 & 2,2 & 0,3 & $-1,6$ & 2,5 \\
\hline & O conteúdo disponibilizado é de alta qualidade & 8,0 & 7,7 & 2,3 & 0,3 & $-1,1$ & 0,9 \\
\hline & $\begin{array}{l}\text { O conteúdo apresentado no ambiente virtual é } \\
\text { relevante para mim }\end{array}$ & 8,0 & 7,8 & 2,3 & 0,3 & $-1,2$ & 1,0 \\
\hline & $\begin{array}{l}\text { Há flexibilidade de horário para realização das } \\
\text { atividades }\end{array}$ & 8,0 & 7,7 & 2,5 & 0,3 & $-1,2$ & 0,8 \\
\hline & $\begin{array}{l}\text { O ambiente virtual de aprendizagem é interativo e } \\
\text { dinâmico }\end{array}$ & 8,0 & 7,6 & 2,5 & 0,3 & $-1,2$ & 0,7 \\
\hline
\end{tabular}




\begin{tabular}{|c|c|c|c|c|c|c|c|}
\hline & Construtos e respectivos itens & Med & Média & $\mathrm{DP}$ & $\mathrm{CV}$ & Assim & Curt \\
\hline \multirow{3}{*}{ 葛 } & Considero as aulas muito boas & 8,0 & 7,3 & 2,5 & 0,4 & $-0,9$ & 0,2 \\
\hline & Os instrutores inspiram segurança & 8,0 & 7,6 & 2,5 & 0,3 & $-1,1$ & 0,5 \\
\hline & Os instrutores dão retorno sobre as tarefas solicitadas & 8,0 & 7,7 & 2,4 & 0,3 & $-1,0$ & 0,4 \\
\hline \multirow{5}{*}{ 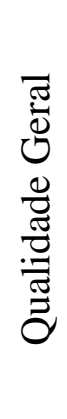 } & O curso apresenta temas atuais & 9,0 & 8,2 & 2,2 & 0,3 & $-1,4$ & 1,7 \\
\hline & $\begin{array}{l}\text { As ferramentas tecnológicas utilizadas no curso } \\
\text { funcionam bem }\end{array}$ & 8,0 & 7,8 & 2,3 & 0,3 & $-1,1$ & 0,7 \\
\hline & $\begin{array}{l}\text { O material do curso apresenta as informações de } \\
\text { forma clara }\end{array}$ & 8,0 & 7,8 & 2,3 & 0,3 & $-1,0$ & 0,5 \\
\hline & $\begin{array}{l}\text { Estudar a distância é melhor do que da maneira } \\
\text { tradicional (presencial) }\end{array}$ & 7,0 & 6,9 & 2,9 & 0,4 & $-0,7$ & $-0,6$ \\
\hline & O curso é de alta qualidade & 8,0 & 7,6 & 2,4 & 0,3 & $-1,0$ & 0,3 \\
\hline \multirow{4}{*}{ 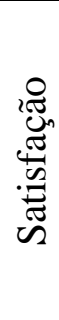 } & $\begin{array}{l}\text { Estou satisfeito com minha decisão de estudar a } \\
\text { distância }\end{array}$ & 9,0 & 8,1 & 2,4 & 0,3 & $-1,3$ & 1,1 \\
\hline & Acertei ao decidir fazer o curso a distância & 9,0 & 8,0 & 2,4 & 0,3 & $-1,3$ & 1,1 \\
\hline & $\begin{array}{l}\text { Minha experiência em estudar a distância tem sido } \\
\text { agradável }\end{array}$ & 9,0 & 7,8 & 2,5 & 0,3 & $-1,2$ & 0,7 \\
\hline & $\mathrm{O}$ curso atende $\mathrm{m}$ & 8,0 & 7,7 & 2,4 & 0,3 & $-1,1$ & 0,7 \\
\hline \multirow{3}{*}{ 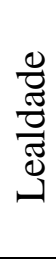 } & $\begin{array}{l}\text { Eu recomendaria este curso a distância aos meus } \\
\text { amigos e familiares }\end{array}$ & 9,0 & 7,8 & 2,6 & 0,3 & $-1,1$ & 0,4 \\
\hline & $\begin{array}{l}\text { Eu certamente faria outro curso de graduação ou uma } \\
\text { pós-graduação a distância }\end{array}$ & 9,0 & 8,1 & 2,5 & 0,3 & $-1,4$ & 1,0 \\
\hline & Pretendo chegar ao final & 10,0 & 9,0 & 2,2 & 0,2 & $-2,5$ & 5,9 \\
\hline \multirow{5}{*}{ 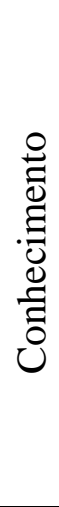 } & $\begin{array}{l}\text { A faculdade é aberta às ideias e sug } \\
\text { para melhoria dos cursos existentes }\end{array}$ & 7,0 & 6,6 & 2,6 & 0,4 & $-0,4$ & $-0,7$ \\
\hline & $\begin{array}{l}\text { A faculdade é aberta às ideias e sugestões dos alunos } \\
\text { para criação de novos cursos/turmas }\end{array}$ & 6,0 & 6,3 & 2,6 & 0,4 & $-0,3$ & $-0,7$ \\
\hline & $\begin{array}{l}\text { A faculdade fornece informações suficientes para o } \\
\text { bom andamento do curso }\end{array}$ & 8,0 & 7,3 & 2,5 & 0,3 & $-0,8$ & $-0,1$ \\
\hline & $\begin{array}{l}\text { Eu gastaria tempo e esforço para compartilhar com a } \\
\text { faculdade minhas ideias e sugestões }\end{array}$ & 7,0 & 7,2 & 2,4 & 0,3 & $-0,8$ & 0,1 \\
\hline & $\begin{array}{l}\text { A faculdade fornece ambiente favorável para que eu } \\
\text { possa expressar minhas opiniões e sugestões }\end{array}$ & 7,0 & 6,9 & 2,6 & 0,4 & $-0,6$ & $-0,5$ \\
\hline \multirow{5}{*}{ 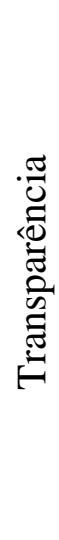 } & A faculdade busca saber minhas preferências & 7,0 & 6,1 & 2,8 & 0,5 & $-0,4$ & $-0,9$ \\
\hline & $\begin{array}{l}\text { A missão e os valores da faculdade estão em linha } \\
\text { com os meus valores }\end{array}$ & 8,0 & 7,4 & 2,4 & 0,3 & $-0,8$ & 0,0 \\
\hline & $\begin{array}{l}\text { A faculdade considera que os alunos exercem um } \\
\text { papel tão importante quanto o dela para andamento do } \\
\text { curso }\end{array}$ & 8,0 & 7,5 & 2,4 & 0,3 & $-0,8$ & 0,0 \\
\hline & $\begin{array}{l}\text { O papel do aluno e o da faculdade são igualmente } \\
\text { importantes para a formação do aluno }\end{array}$ & 9,0 & 8,4 & 2,0 & 0,2 & $-1,4$ & 1,7 \\
\hline & $\begin{array}{l}\text { O nome da faculdade abre portas no mercado de } \\
\text { trabalho independente do desempenho do aluno no } \\
\text { curso }\end{array}$ & 7,0 & 6,7 & 2,7 & 0,4 & $-0,6$ & $-0,6$ \\
\hline
\end{tabular}




\begin{tabular}{|c|c|c|c|c|c|c|c|}
\hline & Construtos e respectivos itens & Med & Média & DP & $\mathrm{CV}$ & Assim & Curt \\
\hline \multirow{4}{*}{ 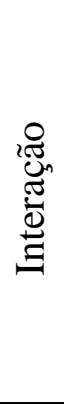 } & $\begin{array}{l}\text { Durante o curso é permitido que os alunos expressem } \\
\text { suas necessidades individuais }\end{array}$ & 8,0 & 7,2 & 2,5 & 0,3 & $-0,8$ & $-0,2$ \\
\hline & $\begin{array}{l}\text { A faculdade transmite aos alunos informações } \\
\text { relevantes acerca do processo de ensino a distância }\end{array}$ & 8,0 & 7,4 & 2,5 & 0,3 & $-0,9$ & 0,1 \\
\hline & $\begin{array}{l}\text { A faculdade permite a completa interação dos alunos } \\
\text { com a instituição }\end{array}$ & 8,0 & 7,2 & 2,5 & 0,3 & $-0,8$ & $-0,2$ \\
\hline & $\begin{array}{l}\text { Espera-se que os alunos sejam proativos na interação } \\
\text { com a faculdade }\end{array}$ & 8,0 & 7,7 & 2,1 & 0,3 & $-0,9$ & 0,6 \\
\hline \multirow{4}{*}{ 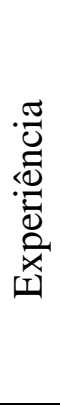 } & $\begin{array}{l}\text { As experiências vividas no curso ficarão em minha } \\
\text { lembrança por um longo tempo }\end{array}$ & 8,5 & 7,7 & 2,6 & 0,3 & $-1,1$ & 0,5 \\
\hline & $\begin{array}{l}\text { As experiências e seus resultados são diferentes } \\
\text { dependendo do aluno }\end{array}$ & 8,0 & 7,8 & 2,2 & 0,3 & $-1,1$ & 0,9 \\
\hline & $\begin{array}{l}\text { Os alunos têm a oportunidade da experimentação e da } \\
\text { prática para ampliar seu conhecimento }\end{array}$ & 7,0 & 7,1 & 2,5 & 0,4 & $-0,7$ & $-0,2$ \\
\hline & $\begin{array}{l}\text { A faculdade fornece boas experiências, além do } \\
\text { benefício de se obter o diploma }\end{array}$ & 8,0 & 7,2 & 2,5 & 0,3 & $-0,9$ & $-0,1$ \\
\hline \multirow{3}{*}{ 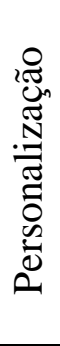 } & $\begin{array}{l}\text { Os benefícios do curso dependem do estudante e de } \\
\text { seu envolvimento nas atividades sugeridas pela } \\
\text { faculdade }\end{array}$ & 9,0 & 8,1 & 2,1 & 0,3 & $-1,4$ & 1,8 \\
\hline & $\begin{array}{l}\text { A faculdade atende às necessidades individuais de } \\
\text { cada aluno }\end{array}$ & 7,0 & 6,9 & 2,6 & 0,4 & $-0,7$ & $-0,4$ \\
\hline & $\begin{array}{l}\text { As necessidades individuais dos alunos são decisivas } \\
\text { no grau de envolvimento com a faculdade }\end{array}$ & 7,0 & 7,1 & 2,3 & 0,3 & $-0,7$ & 0,0 \\
\hline \multirow{8}{*}{ 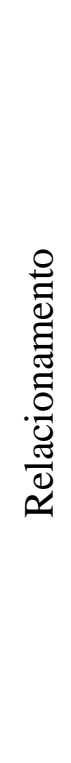 } & $\begin{array}{l}\text { Mantenho relacionamento com colegas além das aulas } \\
\text { presenciais }\end{array}$ & 8,0 & 6,9 & 2,9 & 0,4 & $-0,7$ & $-0,6$ \\
\hline & $\begin{array}{l}\text { A faculdade prepara para desafios do mercado de } \\
\text { trabalho }\end{array}$ & 7,0 & 7,0 & 2,5 & 0,4 & $-0,7$ & $-0,3$ \\
\hline & $\begin{array}{l}\text { A faculdade dispõe de infraestrutura física que permite } \\
\text { ao aluno desfrutar completamente da vida } \\
\text { universitária }\end{array}$ & 7,0 & 7,0 & 2,5 & 0,4 & $-0,7$ & $-0,4$ \\
\hline & Tenho um relacionamento próximo com a faculdade & 7,0 & 6,5 & 2,7 & 0,4 & $-0,5$ & $-0,8$ \\
\hline & $\begin{array}{l}\text { A faculdade possui bom desempenho em avaliações } \\
\text { do governo (ENADE, CAPES) }\end{array}$ & 8,0 & 7,4 & 2,1 & 0,3 & $-0,7$ & 0,2 \\
\hline & $\begin{array}{l}\text { Os alunos escrevem positivamente sobre a faculdade } \\
\text { em redes sociais/mídia }\end{array}$ & 7,0 & 6,9 & 2,4 & 0,3 & $-0,6$ & $-0,3$ \\
\hline & Minha família e amigos consideram a faculdade boa & 7,0 & 7,1 & 2,5 & 0,3 & $-0,8$ & 0,0 \\
\hline & $\begin{array}{l}\text { A faculdade dispõe de atendimento para apoio aos } \\
\text { problemas técnicos ou administrativos dos alunos }\end{array}$ & 8,0 & 7,3 & 2,5 & 0,3 & $-0,9$ & 0,0 \\
\hline
\end{tabular}

Nota. Elaborado pela autora a partir dos dados da amostra. $\mathrm{N}=400$

A frase com maior discordância foi "A faculdade busca saber minhas preferências" e a de maior concordância foi "Pretendo chegar ao final do curso", com médias 6,1 e 9,0, 
respectivamente. Apesar de a grande maioria da amostra ter sido composta de alunos ativos, esta última pergunta não tem muito sentido para os formados e aqueles com matrícula cancelada. A segunda maior concordância foi "O papel do aluno e o da faculdade são igualmente importantes para a formação do aluno", com média 8,4. Considerando a média aritmética dos elementos de um mesmo construto teórico, Conhecimento é aquele com pior avaliação enquanto que Lealdade apresenta, em geral, boas notas, mesmo quando desconsiderada a frase sobre a conclusão do curso (Tabela 14).

Tabela 14

Médias dos construtos

\begin{tabular}{lc}
\hline \multicolumn{1}{c}{ Construtos } & Média \\
\hline Garantia & 7,76 \\
Empatia & 7,47 \\
Capacidade de Resposta & 7,38 \\
Confiabilidade & 7,51 \\
Conteúdo do Site & 7,76 \\
Qualidade Geral & 7,66 \\
Satisfação & 7,90 \\
Lealdade & $8,27^{\mathrm{a}}$ \\
Conhecimento & 6,86 \\
Transparência & 7,21 \\
Interação & 7,38 \\
Experiência & 7,43 \\
Personalização & 7,36 \\
Relacionamento & 7,01 \\
\hline
\end{tabular}

Nota. Elaborado pela autora a partir do cálculo de média aritmética dos itens de cada construto. ${ }^{\text {a }} 7,92$ quando desconsiderada a frase "chegar ao final do curso". $\mathrm{N}=400$

Uma das premissas da técnica de análise de equações estruturais baseada em covariância (LISREL) é que os dados possuam distribuição Normal. O teste de Kolmogorov-Smirnov (Blalock, 1979) indicou rejeição da hipótese de normalidade $(\mathrm{p}<0,001)$; portanto, a decisão foi pelo uso da modelagem de equações estruturais baseada em mínimos quadrados parciais (PLS-SEM), mais permissiva neste quesito (Hair et al., 2017). A próxima seção discute os resultados da modelagem. 


\subsection{Modelo de Equações Estruturais: PLS-SEM}

Para responder aos objetivos desta pesquisa, foi utilizada a técnica de modelagem de equações estruturais, conforme modelo teórico proposto no Capítulo 4. Esta seção apresenta os resultados desta análise separados entre o modelo de mensuração e o estrutural. O primeiro trata das relações entre as variáveis observadas e as variáveis latentes (construtos) e deve ser considerado com cautela naquelas de mais alta ordem (Wetzels, Odekerken-Schröder \& van Oppen, 2009; Becker, Klein \& Wetzels, 2012); o modelo estrutural discute as relações entre as variáveis latentes, tornando possível entender a dinâmica das conexões propostas em teoria.

Como visto no final da Seção 6.2, os dados não seguem distribuição Normal - premissa para o modelo de equações estruturais baseado em covariância -; então, decidiu-se pela utilização do método de mínimos quadrados parciais (PLS-SEM), com uso do software SmartPLS 3.2.6.

\subsubsection{Modelo de mensuração}

No modelo proposto, nem todos os construtos são de primeira ordem, como qualidade percebida, coprodução e valor em uso (de segunda ordem) e cocriação de valor (de terceira ordem). Becker et al. (2012) apresentam, comparativamente, diferentes métodos para lidar com construtos de ordem superior em modelos reflexivos-formativos, indicando que, em geral, repetir os indicadores presentes no construto de primeira ordem nos demais construtos com o caminho partindo do indicadores para o construto (mode B) é o que traz os melhores resultados, inclusive quando os construtos possuem números não iguais de indicadores. Em contrapartida, como são usados os mesmos indicadores dos construtos de primeira ordem nos demais, a relação é praticamente perfeita (a variância do construto de segunda ordem é totalmente explicada pelos construtos de primeira ordem), fazendo com que não sejam visualizados possíveis efeitos de outras variáveis latentes - no caso do modelo apresentado na Figura 6, esta situação seria observada na avaliação do efeito da cocriação de valor na qualidade percebida, indicando que não há relação entre estas duas informações quando, na realidade, trata-se de questão de limitação sistêmica. 
Uma alternativa para a questão levantada é utilizar o método dos dois estágios (two stages), que consiste em, primeiramente, se obter o valor da variável latente de primeira ordem e usar estes valores como se fossem indicadores da variável de segunda ordem; caso haja construtos de ordens superiores a duas, o processo é repetido até que a variável latente de maior ordem possa ser escrita como se fosse de primeira ordem; o modelo estrutural é avaliado, assim, apenas como "variáveis de primeira ordem". Ringle, Sarstedt e Straub (2012) sugerem que construtos formativos sempre sejam calculados usando este método. Na simulação realizada por Becker et al. (2012), foi verificado que esse método apresenta resultados ligeiramente piores do que os do método descrito anteriormente, sendo também recomendável.

Escolhida a tratativa para os construtos de ordem superior, pode ser executada a análise do modelo de mensuração, iniciando pela observação da qualidade de discriminação dos indicadores em cada construto. Como se trata de avaliação de distinção das dimensões, esta análise foi realizada antes do método de dois estágios, tratado anteriormente. Foi utilizado o método path weighting scheme, com número máximo de 300 iterações $\left(10^{-10}\right.$ como critério de parada).

A primeira execução, com todas as frases indicadas na Tabela 13, apresentou resultados insatisfatórios com relação à validação discriminante usando o critério de Fornell-Larcker, que estabelece que a raiz quadrada da AVE de um construto deve ser maior do que as correlações entre este construto e os demais (Tabela 15). 
Tabela 15

Avaliação do critério de Fornell-Larcker - primeira execução

\begin{tabular}{|c|c|c|c|c|c|c|c|c|c|c|c|c|}
\hline 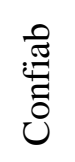 & 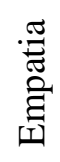 & 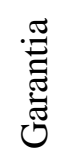 & 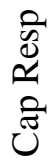 & $\stackrel{\mathscr{V}}{\mathscr{S}}$ & లే & 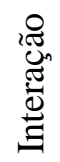 & 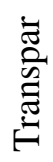 & $\begin{array}{l}\overline{0} \\
\vec{x} \\
\text { a }\end{array}$ & 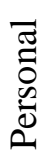 & $\frac{\widetilde{0}}{\frac{\pi}{0}}$ & 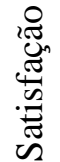 & $\begin{array}{l}\frac{\mathbb{E}}{\tilde{J}} \\
\frac{\pi}{\tilde{J}} \\
.\end{array}$ \\
\hline
\end{tabular}

\begin{tabular}{l|l|llllllllllll}
\hline Confiab & $\mathbf{0 , 9 2}$ & 0,89 & 0,88 & 0,85 & 0,76 & 0,75 & 0,73 & 0,76 & 0,75 & 0,73 & 0,78 & 0,70 & 0,68 \\
Empatia & 0,89 & $\mathbf{0 , 9 3}$ & 0,86 & 0,91 & 0,70 & 0,73 & 0,74 & 0,74 & 0,73 & 0,72 & 0,76 & 0,67 & 0,63 \\
Garantia & 0,88 & 0,86 & $\mathbf{0 , 8 9}$ & 0,84 & 0,72 & 0,69 & 0,70 & 0,71 & 0,71 & 0,69 & 0,72 & 0,68 & 0,64 \\
Cap Resp & 0,85 & 0,91 & 0,84 & $\mathbf{0 , 9 2}$ & 0,70 & 0,71 & 0,72 & 0,72 & 0,70 & 0,70 & 0,74 & 0,64 & 0,61 \\
Site & 0,76 & 0,70 & 0,72 & 0,70 & $\mathbf{0 , 8 7}$ & 0,74 & 0,78 & 0,80 & 0,77 & 0,77 & 0,82 & 0,76 & 0,76 \\
Conh & 0,75 & 0,73 & 0,69 & 0,71 & 0,74 & 0,83 & 0,87 & 0,87 & 0,83 & 0,82 & 0,87 & 0,65 & 0,63 \\
Interação & 0,73 & 0,74 & 0,70 & 0,72 & 0,78 & 0,87 & $\mathbf{0 , 8 7}$ & 0,86 & 0,83 & 0,84 & 0,86 & 0,69 & 0,67 \\
Transpar & 0,76 & 0,74 & 0,71 & 0,72 & 0,80 & 0,87 & 0,86 & 0,80 & 0,83 & 0,85 & $\mathbf{0 , 9 1}$ & 0,70 & 0,69 \\
Exper & 0,75 & 0,73 & 0,71 & 0,70 & 0,77 & 0,83 & 0,83 & 0,83 & 0,83 & 0,82 & 0,88 & 0,71 & 0,69 \\
Personal & 0,73 & 0,72 & 0,69 & 0,70 & 0,77 & 0,82 & 0,84 & 0,85 & 0,82 & 0,85 & 0,86 & 0,69 & 0,66 \\
Relacion & 0,78 & 0,76 & 0,72 & 0,74 & 0,82 & $\mathbf{0 , 8 7}$ & 0,86 & $\mathbf{0 , 9 1}$ & $\mathbf{0 , 8 8}$ & $\mathbf{0 , 8 6}$ & 0,82 & 0,73 & 0,71 \\
Satisfação & 0,70 & 0,67 & 0,68 & 0,64 & 0,76 & 0,65 & 0,69 & 0,70 & 0,71 & 0,69 & 0,73 & $\mathbf{0 , 9 3}$ & $\mathbf{0 , 9 0}$ \\
Lealdade & 0,68 & 0,63 & 0,64 & 0,61 & 0,76 & 0,63 & 0,67 & 0,69 & 0,69 & 0,66 & 0,71 & 0,90 & 0,85 \\
\hline
\end{tabular}

Nota. Elaborado pela autora. Na diagonal (destacada com borda) encontra-se a raiz quadrada do AVE e nos demais campos, as correlações entre construtos. Números em negrito representam o maior valor observado para cada construto. $\mathrm{N}=400$

Para melhoria dos índices, foram identificados os itens (no máximo um de cada dimensão) que acarretavam menor consistência interna para seus construtos, medida por meio do alpha de Cronbach (Hair et al., 2017) e outra execução foi realizada, ainda apresentando resultados insatisfatórios. Novamente foram avaliadas as consistências internas com a retirada dos itens com maior dissociação do que se desejava obter e avaliada a validade discriminante. Este processo foi realizado [por nove vezes] até que houvesse discriminação entre os construtos pelo critério de Fornell-Larcker - os resultados podem ser observados na Tabela 16 (avaliação antes da validação convergente e medidas de confiabilidade). Como apontado na Seção 6.2, a frase referente à conclusão do curso foi excluída da lealdade por ser passível de confusão de resposta nos alunos formados ou com matrícula cancelada. 
Tabela 16

Avaliação do critério de Fornell-Larcker - pré-validação convergente e confiabilidade

\begin{tabular}{|c|c|c|c|c|c|c|c|c|c|c|c|}
\hline 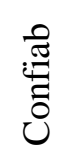 & 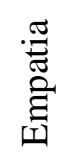 & & 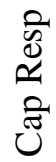 & $\stackrel{\oplus}{*}$ & ठేี & 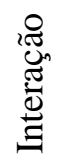 & 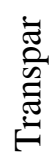 & $\begin{array}{l}\bar{\varpi} \\
\bar{x} \\
\text { x. }\end{array}$ & 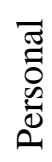 & $\frac{\tilde{0}}{\frac{0}{0}}$ & 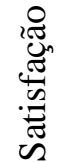 \\
\hline
\end{tabular}

\begin{tabular}{|c|c|c|c|c|c|c|c|c|c|c|c|c|c|}
\hline Confiab & 0,92 & 0,89 & 0,88 & 0,85 & 0,76 & 0,73 & 0,73 & 0,73 & 0,74 & 0,74 & 0,78 & 0,70 & 0 , \\
\hline Empa & 0,89 & 0,93 & 0,86 & 0,91 & 0,70 & 0,71 & 0,73 & 0,72 & 0,74 & 0,72 & 0,75 & 0,67 & 0,67 \\
\hline Garantia & 88 & 0,86 & $\mathbf{0 , 8 9}$ & 0,84 & 0,72 & 0,68 & 0,68 & 0,67 & 0,69 & 0,69 & 0,71 & 0,68 & 0,67 \\
\hline Cap Resp & 0,85 & 0,91 & 0,84 & 0,92 & 0,70 & 0,69 & 0,70 & 0,69 & 0,70 & 0,70 & 0,72 & 0,64 & 0,65 \\
\hline Site & 0,76 & 0,70 & 0,72 & 0,70 & $\mathbf{0 , 8 7}$ & 0,72 & 0,78 & 0,77 & 0,76 & 0,77 & 0,80 & 0,76 & 0,78 \\
\hline Conh & 0,73 & 0,71 & 0,68 & 0,69 & 0,72 & 0,88 & 0,85 & 0,86 & 0,81 & 0,80 & 0,83 & 0,65 & 0,65 \\
\hline Inter & 0,73 & 0,73 & 0,68 & 0,70 & 0,78 & 0,85 & 0,91 & 0,86 & 0,82 & 0,82 & 0,83 & 0,67 & 0,68 \\
\hline Transpar & 0,73 & 0,72 & 0,67 & 0,69 & 0,77 & 0,86 & 0,86 & $\mathbf{0 , 8 8}$ & 0,83 & 0,84 & 0,87 & 0,68 & 0,70 \\
\hline Exper & 0,74 & 0,74 & 0,69 & 0,70 & 0,76 & 0,81 & 0,82 & 0,83 & $\mathbf{0 , 8 9}$ & 0,81 & 0,88 & 0,70 & 0,71 \\
\hline Personal & 0,74 & 0,72 & 0,69 & 0,70 & 0,77 & 0,80 & 0,82 & 0,84 & 0,81 & 0,85 & 0,83 & 0,69 & 0,68 \\
\hline Relacion & 0,78 & 0,75 & 0,71 & 0,72 & 0,80 & 0,83 & 0,83 & 0,87 & 0,88 & 0,83 & 0,90 & 0,71 & 0,73 \\
\hline Satisfação & 0,70 & 0,67 & 0,68 & 0,64 & 0,76 & 0,65 & 0,67 & 0,68 & 0,70 & 0,69 & 0,71 & 0,93 & 0,89 \\
\hline Lealdade & 0,71 & 0,67 & 0,67 & 0,65 & 0,78 & 0,65 & 0,68 & 0,70 & 0,71 & 0,68 & 0,73 & 0,89 & 0,93 \\
\hline
\end{tabular}

Nota. Elaborado pela autora. Na diagonal (destacada com borda) encontra-se a raiz quadrada do AVE e nos demais campos, as correlações entre construtos. Números em negrito representam o maior valor observado para cada construto. Resultados obtidos antes da validação convergente e medida de confiabilidade. $\mathrm{N}=400$

Apesar de o critério ter sido atingido, nota-se alta correlação (valores acima de 0,7 ) em boa parte dos construtos. Foram, então, avaliadas as cargas fatoriais dos indicadores (Tabela 17). Conforme destacado por Hair et al. (2017), o esperado é que as cargas fatoriais dos indicadores sejam maiores do que 0,708 para os construtos a que estão associadas e sempre apresentem valores mais altos nestes construtos do que nos demais. A Tabela 17 mostra que este critério é estabelecido. 
Tabela 17

Cargas fatoriais - pré-validação convergente e confiabilidade

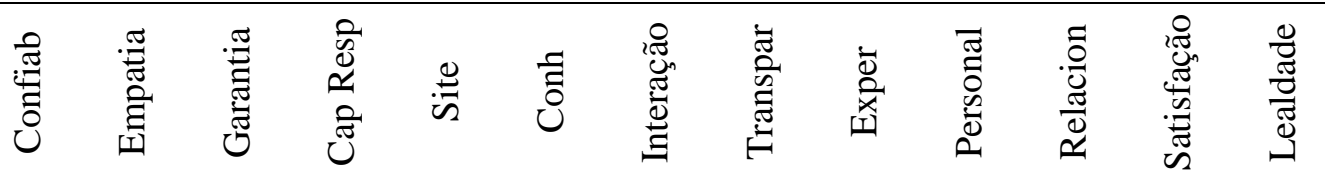

\begin{tabular}{|c|c|c|c|c|c|c|c|c|c|c|c|c|c|}
\hline b1 & ,92 & 0,78 & ,78 & 0,75 & 0,80 & 0,70 & 0,71 & 0,72 & 0,73 & 0,71 & 0,77 & 0,72 & \\
\hline Conf & ,94 & 83 & 84 &, 77 &, 67 & 0,66 & 0,64 & 0,64 & 0,68 & 0,65 &, 70 & 0,62 & \\
\hline 03 & & 0,84 & 0,81 & 0,83 & 0,61 & 0,65 & 0,66 & & & 0,65 & & & \\
\hline $\mathrm{mp}$ & 83 & $\mathbf{0 , 9 3}$ & 78 & 0,84 & 0,62 & 0,65 & 0,66 & 0,67 & 066 & 0,67 &, 69 &, 59 & 0,58 \\
\hline & 81 & 93 & 78 & 84 &, 63 & 0,67 & 0,68 & 0,66 &, 67 &, 67 & ,67 & ,61 & 0,60 \\
\hline & & 94 & 81 & 0,86 & 0,70 & 0,69 & 0,70 & 0,70 & & 0,69 &, 74 &, 67 & 0,65 \\
\hline 4 & 80 & ,92 & 0,82 & 0,83 & 0,67 & 0,63 & 0,66 & 0,65 & 0,67 & 0,63 &, 68 & 0,63 & 0,64 \\
\hline $\operatorname{ar}$ & 9 & 76 & 0,90 & 0,73 & 0,64 & 0,58 & 0,56 & 0,56 & 62 & 0,61 & 0,63 & 0,59 & 0,61 \\
\hline & & 75 & $\mathbf{0 , 8 6}$ & 70 & 0,63 & 0,57 & 0,59 & 0,60 & & 0,60 & & 0,60 & 0,60 \\
\hline 3 & 81 & 0,80 & 88 & 0,83 & 0,64 & 0,64 & 0,68 & 0,63 & 0,62 & 0,64 & 0,65 & 0,61 & 0,58 \\
\hline & 80 &, 74 & 0,92 & 0,73 & 0,66 & 0,61 & 0,59 & 0,59 & 0,63 & 0,61 & 0,65 & 0,59 & 0,59 \\
\hline & & ,83 & & 0,92 & 0,65 & 0,63 & 0,65 & 0,64 & & 0,64 & &, 60 & 60 \\
\hline S & 76 & 0,82 & 0,77 & 0,92 & 0,62 & 0,62 & 0,63 & 0,62 & 0,62 & 0,64 & 0,65 & 0,60 & 0,61 \\
\hline & & & 77 & 93 & 0,62 & 0,65 & 0,64 & 0,65 & & 0,66 & & 61 & 60 \\
\hline Resp4 & 0,78 & 0,84 & 0,81 & 0,91 & 0,66 & 0,63 & 0,66 & 0,64 & 0,64 & 0,63 & 0,65 & 0,57 & 0,58 \\
\hline ite1 & 67 & 61 & 62 & 0,61 & 0,89 & 0,63 & 0,69 & 0,67 & 0,65 & 0,65 &, 68 & 0,63 & 0,65 \\
\hline & & & & & & & & & & & & & \\
\hline te & 66 & 0,61 & 0,63 &, 59 & 0,90 & 0,60 & 0,68 & 0,68 & 0,64 & 0,63 & 0,68 & 0,64 & 0,67 \\
\hline & & & 67 & & & & 0, & 67 & & & & 67 & 69 \\
\hline Site & 75 & 0,68 & 0,70 & 0,68 & 0,90 & 0,68 & 0,70 & 0,71 & 0,73 & 0,74 & 0,78 & 0,72 & 0,74 \\
\hline ite & 69 & 61 & 0,67 & 0,62 & 0,89 & 0,65 & 0,67 & 0,66 & 0,69 & 0,68 &, 71 &, 69 & 0,71 \\
\hline Site7 & & 0,49 & 0,51 & 0,48 & 0,71 & 0,49 & 0,57 & 0,57 & & &, 58 & 0,56 & 0,54 \\
\hline Site8 & 67 & 0,64 & 0,60 & 0,63 & $\mathbf{0 , 8 8}$ & 0,68 & 0,73 & 0,71 & 0,72 & 0,72 & 0,73 & 0,73 & 0,73 \\
\hline & & & & & & & & & & & & 55 & 54 \\
\hline & & 0,62 & & & & & 0,67 & 0,71 & & & &, 50 & 51 \\
\hline onl &, 72 & 0,65 & 0,66 & 0,64 & 0,73 & $\mathbf{0 , 8 7}$ & 0,81 & 0,78 & 0,78 & 0,76 & 0,80 & 0,65 & 0,67 \\
\hline & & & & & & & $\mathbf{0 , 9 0}$ & 0,77 & & & & 0,61 & 0,61 \\
\hline Inter2 & ,69 & 0,66 & 0,66 & 0,64 & 0,73 & 0,75 & $\mathbf{0 , 9 2}$ & 0,76 & 0,74 & 0,76 & 0,74 & 0,64 & 0,65 \\
\hline Inter3 & 67 & 0,66 & 0,60 & 0,65 & 0,70 & 0,81 & $\mathbf{0 , 9 2}$ & 0,82 & 0,76 & 0,76 & 0,78 & 0,58 & 0,60 \\
\hline & & & & & $\overline{0,6}$ & 0,78 & 0,76 & 0,87 & & & & 0,58 & 0,59 \\
\hline Transp2 & 0,65 & 0,60 & 0,60 & 0,56 & 0,69 & 0,72 & 0,73 & 0,88 & 0,71 & 0,74 & 0,76 & 0,62 & 0,65 \\
\hline Transp & 0,63 & 0,64 & 0,60 & 0,65 & 0,70 & 0,77 & 0,79 & 0,90 & 0,75 & 0,76 & 0,77 & 0,60 & 0,63 \\
\hline Exp1 & 0,65 & 0,63 & 0,61 & 0,59 & 0,66 & 0,69 & 0,71 & 0,70 & 0,88 & 0,67 & 0,75 & 0,64 & 0,64 \\
\hline Exp & 0,65 & 0,67 & 0,58 & 0,62 & 0,65 & 0,71 & 0,72 & 0,73 & & 0,71 & 0,77 & 0,58 & 0,59 \\
\hline Exp4 & 0,69 & 0,67 & 0,65 & 0,67 & 0,72 & 0,76 & 0,77 & 0,78 & 0,92 & 0,80 & 0,84 & 0,64 & 0,67 \\
\hline & 0,53 & 0,49 & 0,55 & 0,50 & 0,60 & 0,58 & 0,58 & 0,58 & 0,60 & $\mathbf{0 , 7 9}$ & 0,59 & 0,53 & 0,51 \\
\hline & 0,71 & 0,68 & 0,64 & 0,66 & 0,74 & 0,77 & 0,81 & 0,81 & 0,80 & $\mathbf{0 , 8 9}$ & 0,83 & 0,67 & 0,67 \\
\hline Person3 & 0,62 & 0,65 & 0,57 & 0,62 & 0,61 & 0,68 & 0,69 & 0,73 & 0,67 & $\mathbf{0 , 8 7}$ & 0,69 & 0,54 & 0,54 \\
\hline
\end{tabular}




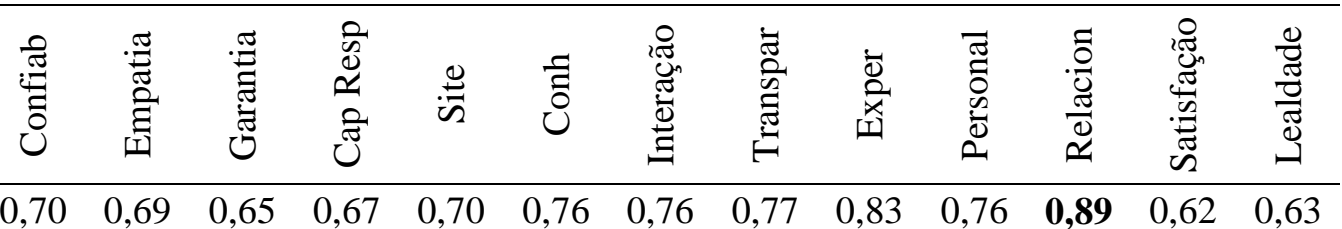

\begin{tabular}{llllllllllllll}
\hline Relac2 & 0,70 & 0,69 & 0,65 & 0,67 & 0,70 & 0,76 & 0,76 & 0,77 & 0,83 & 0,76 & $\mathbf{0 , 8 9}$ & 0,62 & 0,63 \\
Relac4 & 0,68 & 0,66 & 0,62 & 0,64 & 0,67 & 0,73 & 0,72 & 0,77 & 0,77 & 0,70 & $\mathbf{0 , 8 9}$ & 0,63 & 0,62 \\
Relac6 & 0,67 & 0,64 & 0,63 & 0,61 & 0,73 & 0,74 & 0,75 & 0,80 & 0,75 & 0,76 & $\mathbf{0 , 8 9}$ & 0,64 & 0,67 \\
Relac7 & 0,74 & 0,69 & 0,67 & 0,67 & 0,76 & 0,77 & 0,75 & 0,79 & 0,82 & 0,78 & $\mathbf{0 , 9 2}$ & 0,68 & 0,72 \\
\hline Satisf1 & 0,61 & 0,60 & 0,59 & 0,57 & 0,68 & 0,58 & 0,59 & 0,60 & 0,62 & 0,61 & 0,62 & $\mathbf{0 , 9 5}$ & 0,83 \\
Satisf2 & 0,62 & 0,58 & 0,60 & 0,56 & 0,67 & 0,56 & 0,58 & 0,58 & 0,60 & 0,60 & 0,60 & $\mathbf{0 , 9 4}$ & 0,83 \\
Satisf3 & 0,68 & 0,65 & 0,64 & 0,62 & 0,73 & 0,62 & 0,66 & 0,65 & 0,69 & 0,67 & 0,71 & $\mathbf{0 , 9 4}$ & 0,86 \\
Satisf4 & 0,71 & 0,67 & 0,68 & 0,65 & 0,73 & 0,65 & 0,67 & 0,69 & 0,69 & 0,69 & 0,74 & $\mathbf{0 , 9 0}$ & 0,80 \\
\hline Leal1 & 0,74 & 0,69 & 0,70 & 0,68 & 0,79 & 0,67 & 0,70 & 0,70 & 0,72 & 0,69 & 0,75 & 0,86 & $\mathbf{0 , 9 4}$ \\
Leal2 & 0,57 & 0,54 & 0,53 & 0,53 & 0,65 & 0,53 & 0,57 & 0,60 & 0,60 & 0,57 & 0,61 & 0,80 & $\mathbf{0 , 9 2}$ \\
\hline
\end{tabular}

Nota. Elaborado pela autora. Números em negrito representam a maior carga fatorial do indicador. Resultados obtidos antes da validação convergente e medida de confiabilidade. $\mathrm{N}=400$

Embora os dois critérios anteriores tenham sido alcançados, decidiu-se pela observação do Heterotrait-Monotrait Ratio (HTMT), que, segundo recomendação de Hair et al. (2017), deve apresentar valores menores do que 1 (Tabela 18).

Tabela 18

Estatística HTMT - pré-validação convergente e confiabilidade

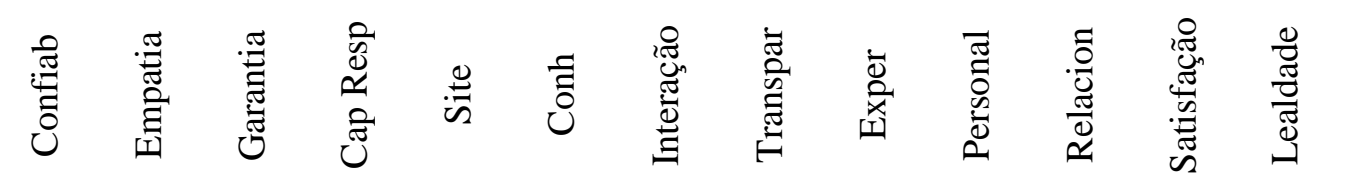

\begin{tabular}{lllllllllllllll}
\hline Confiab & & & & & & & & & & & & \\
Empatia & 0,96 & & & & & & & & & & & \\
Garantia & 0,97 & 0,92 & & & & & & & & & & \\
Cap Resp & 0,93 & 0,96 & 0,91 & & & & & & & & & \\
Site & 0,81 & 0,74 & 0,78 & 0,74 & & & & & & & & \\
Conh & 0,82 & 0,79 & 0,76 & 0,77 & 0,78 & & & & & & & \\
Interação & 0,81 & 0,79 & 0,75 & 0,77 & 0,84 & 0,96 & & & & & & \\
Transpar & 0,83 & 0,80 & 0,76 & 0,77 & 0,85 & 0,99 & 0,98 & & & & & \\
Exper & 0,84 & 0,81 & 0,77 & 0,77 & 0,83 & 0,93 & 0,93 & 0,96 & & & & \\
Personal & 0,85 & 0,81 & 0,80 & 0,80 & 0,87 & 0,95 & 0,96 & 0,99 & 0,96 & & & \\
Relacion & 0,85 & 0,80 & 0,78 & 0,78 & 0,85 & 0,93 & 0,91 & 0,98 & 0,98 & 0,96 & & \\
Satisfação & 0,76 & 0,71 & 0,73 & 0,68 & 0,80 & 0,71 & 0,73 & 0,75 & 0,76 & 0,78 & 0,76 & \\
Lealdade & 0,80 & 0,74 & 0,76 & 0,72 & 0,86 & 0,76 & 0,78 & 0,82 & 0,83 & 0,82 & 0,83 & 0,99 \\
\hline
\end{tabular}

Nota. Elaborado pela autora. Resultados obtidos antes da validação convergente e medida de confiabilidade. $\mathrm{N}=400$ 
Estando a validade discriminante satisfeita, verificou-se a validade convergente e a métrica de confiabilidade dos dados. Para avaliação da validade, foi utilizada a variância média extraída (AVE), sendo aceitáveis valores acima de 50\% (Hair et al., 2017).

Para mensurar a confiabilidade, Hair et al. (2017) recomendam o uso tanto do alpha de Cronbach quanto da Confiabilidade Composta (CC) - com valores de referência acima de 0,7 para ambos e CC menor do que 0,95. Este limite superior identifica redundância, situação indesejada por representar que todos os itens estão medindo exatamente o mesmo fenômeno. A Tabela 19 resume as medidas obtidas na amostra para a validade convergente e a confiabilidade.

Tabela 19

Medidas de validade convergente e confiabilidade dos indicadores

\begin{tabular}{lccc}
\hline & Alpha de Cronbach & $\begin{array}{c}\text { Confiabilidade } \\
\text { Composta }\end{array}$ & AVE \\
\hline Confiabilidade & 0,904 & 0,940 & 0,838 \\
Empatia & 0,947 & 0,962 & 0,863 \\
Garantia & 0,911 & 0,937 & 0,789 \\
Capacidade de Resposta & 0,939 & 0,956 & 0,845 \\
Site & 0,953 & 0,961 & 0,758 \\
Conhecimento & 0,858 & 0,914 & 0,779 \\
Interação & 0,895 & 0,935 & 0,827 \\
Transparência & 0,859 & 0,914 & 0,781 \\
Experiência & 0,870 & 0,920 & 0,794 \\
Personalização & 0,808 & 0,886 & 0,723 \\
Relacionamento & 0,920 & 0,944 & 0,807 \\
Satisfação & 0,949 & 0,963 & 0,868 \\
Lealdade & 0,845 & 0,928 & 0,866 \\
\hline
\end{tabular}

Nota. Elaborado pela autora. $\mathrm{N}=400$

Utilizando os critérios mencionados, nota-se que os construtos Site $(\mathrm{CC}=0,961)$, Capacidade de Resposta $(C C=0,956)$, Empatia $(C C=0,962)$ e Satisfação $(C C=0,963)$ mostram sinais de redundância. Para mitigar esta condição, foram excluídas as variáveis que apresentavam altíssima correlação com as demais (maiores que 0,8 ) e cuja retirada gerasse pouco [ou menor] impacto no alpha de Cronbach. 
Após as exclusões, foram novamente verificadas as condições de validade discriminante e convergente, além das medidas de confiabilidade e concluiu-se pela aceitação de todas as métricas (tabelas finais podem ser encontradas no Apêndice C).

O último passo do modelo de mensuração refere-se à avaliação dos construtos geradores da qualidade percebida e da cocriação de valor quanto à multicolinearidade. Para tanto, foram inspecionados os fatores de inflação de variância (VIF), medida importada da análise de regressão (Tabela 20) e que, conforme destacam Ranjan e Read (2016), tem sido utilizada em estudos cujo objetivo é a construção de índices. Para Kleinbaum, Kupper, Muller e Nizam (1998), deve-se considerar que há multicolinearidade quando VIF $\geq 10$. Embora alguns autores indiquem que este valor deveria manter-se menor que 3 (Diamantopoulos \& Siguaw, 2006) ou menor que 5 (Hair et al., 2017), entende-se que, sendo as perguntas feitas relacionadas ao comportamento do aluno, é difícil obter total dissociação entre respostas, sendo, portanto, aceitável uma medida menos restritiva.

Tabela 20

Avaliação de multicolinearidade (VIF) entre construtos de $1^{a}$ ordem referentes a cada dimensão

\begin{tabular}{lccc} 
& Qualidade Percebida & Coprodução & Valor em Uso \\
\hline Confiabilidade & 6,947 & & \\
Empatia & 5,485 & & \\
Garantia & 5,497 & & \\
Capacidade de Resposta & 5,023 & & \\
Site & 3,718 & & \\
\hline Conhecimento & & 4,564 & \\
Interação & 4,659 & 4,960 \\
Transparência & 4,962 & 3,616 \\
\hline Experiência & & 5,488 \\
Personalização & & & \\
Relacionamento & & & \\
\hline
\end{tabular}

Nota. Elaborado pela autora. $\mathrm{N}=400$

Estando todos os critérios de validade satisfeitos, pode-se seguir para a obtenção do modelo de mensuração completo com a utilização do método de 2 estágios (two stages). Conforme explicitado no início desta subseção, este método indica que, no primeiro 
estágio, os construtos de ordem superior sejam transformados em construtos de primeira ordem e, no segundo estágio, estes construtos de primeira ordem sejam avaliados nos modelo de mensuração e estrutural no lugar dos de ordem superior.

Para a Qualidade Percebida, foram utilizados os construtos de Confiabilidade, Empatia, Garantia, Capacidade de Resposta e Site com os indicadores validados. A Figura 10 ilustra o processo de transformação.

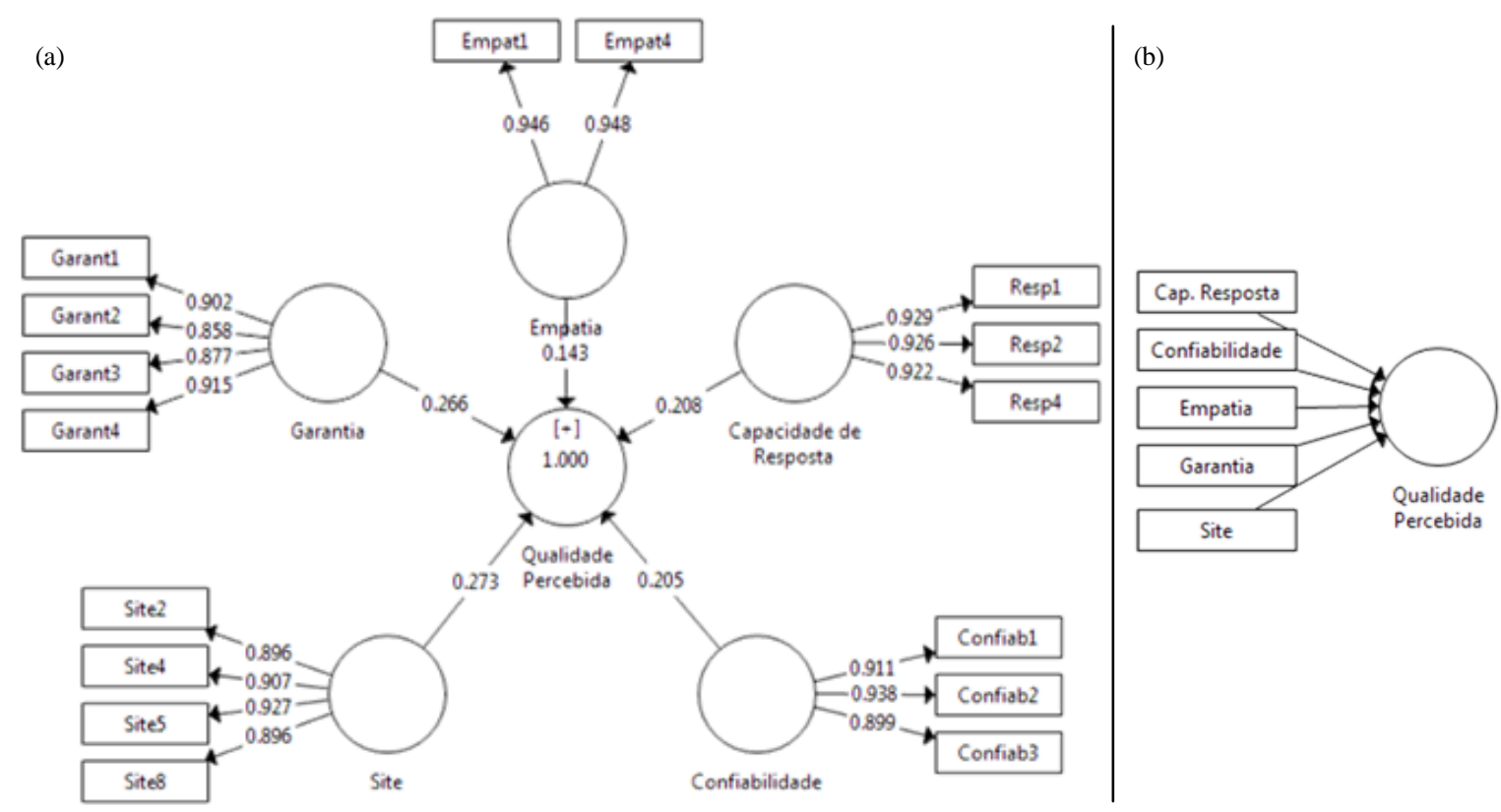

Figura 10. Modelo de mensuração para qualidade percebida. (a) Qualidade percebida como construto de segunda ordem. (b) Qualidade percebida como construto de primeira ordem. $\mathrm{N}=400$

Como a Cocriação de Valor é uma dimensão de terceira ordem, deve-se, primeiramente, transformar os construtos de segunda ordem (Coprodução e Valor em Uso) em construtos de primeira ordem para, em seguida, gerar a dimensão de interesse (Figura 11). 
(a)

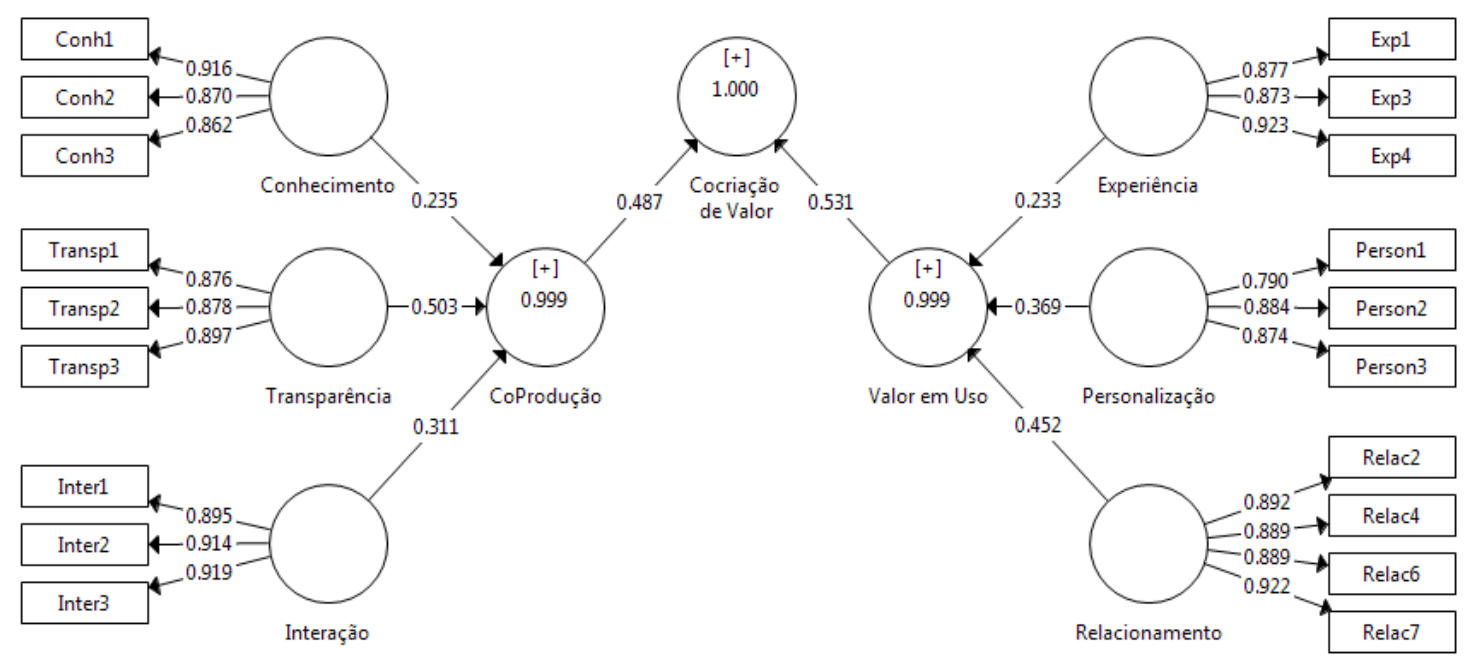

(b)

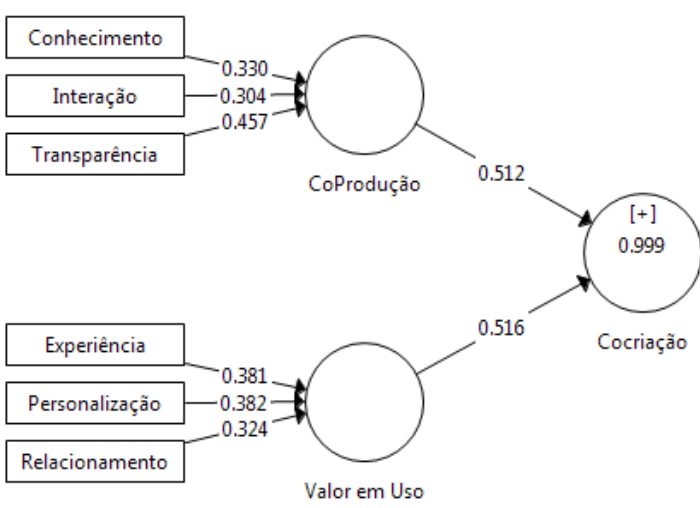

(c)

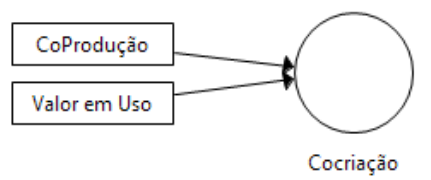

Figura 11. Modelo de mensuração para cocriação de valor. (a) Cocriação de valor como construto de terceira ordem. (b) Cocriação de valor como construto de segunda ordem. (c) Cocriação de Valor como construto de primeira ordem. $\mathrm{N}=400$

Estando realizado o primeiro passo do método dos 2 estágios (two stages) pode-se representar o modelo de mensuração completo (Figura 12). 


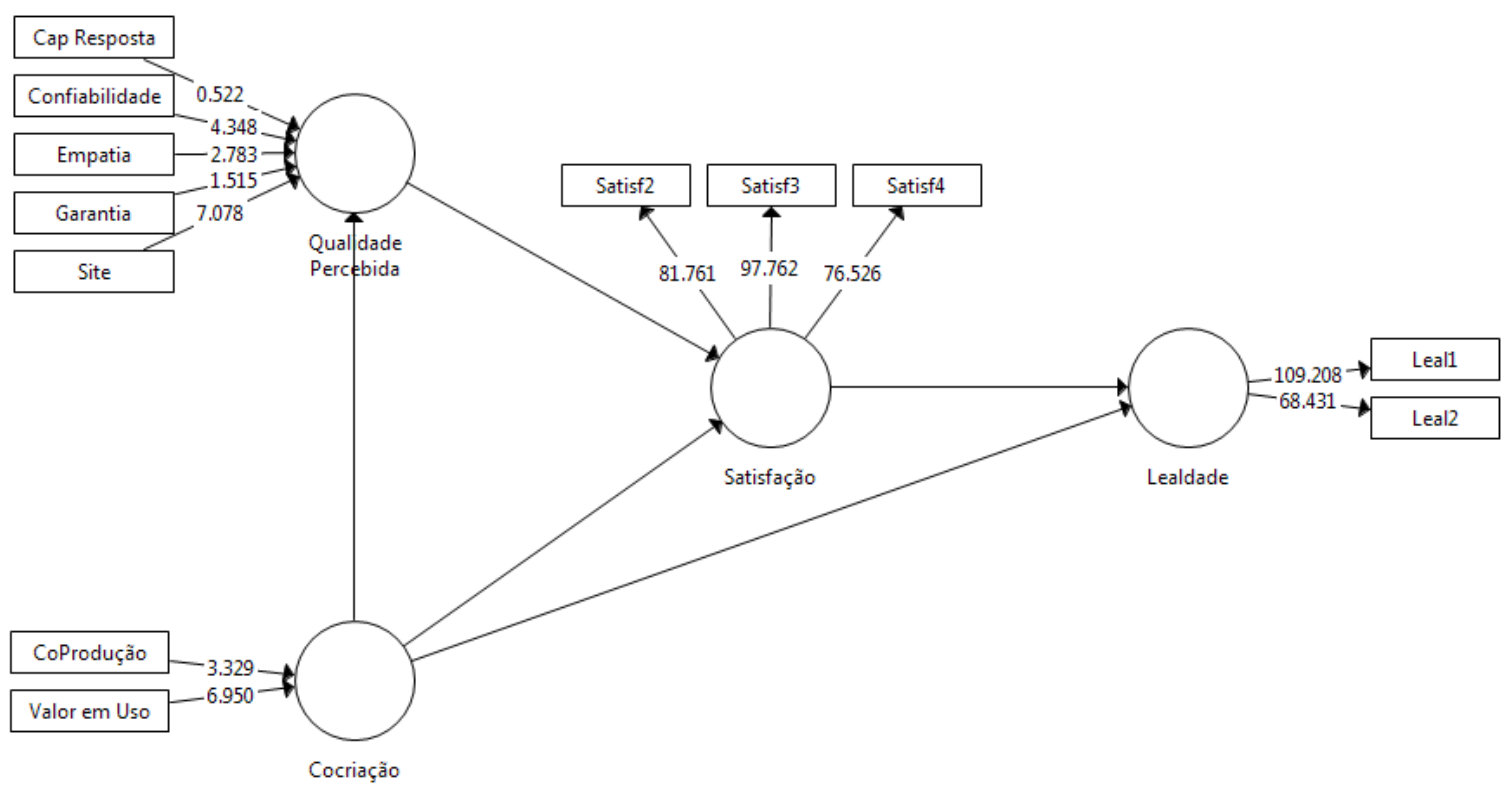

Figura 12. Avaliação do modelo de mensuração - primeira execução. $\mathrm{t}>1,96 . \mathrm{N}=400$

Observando os valores da estatística t calculada por meio da técnica de bootstrap com 5.000 reamostragens, verifica-se que as informações de Capacidade de Resposta e Garantia não são significativas ( $\mathrm{p}>5 \%$; $<1,96)$ para a obtenção da dimensão Qualidade Percebida, sendo retiradas da modelagem; primeiramente foi retirada a de menor significância (Capacidade de Resposta) e nova execução foi realizada, com Garantia mantendo-se não significativa. Houve sua retirada e outra execução foi realizada; sendo todos os coeficientes significativos, a avaliação do modelo de mensuração está finalizada (Figura 13). 


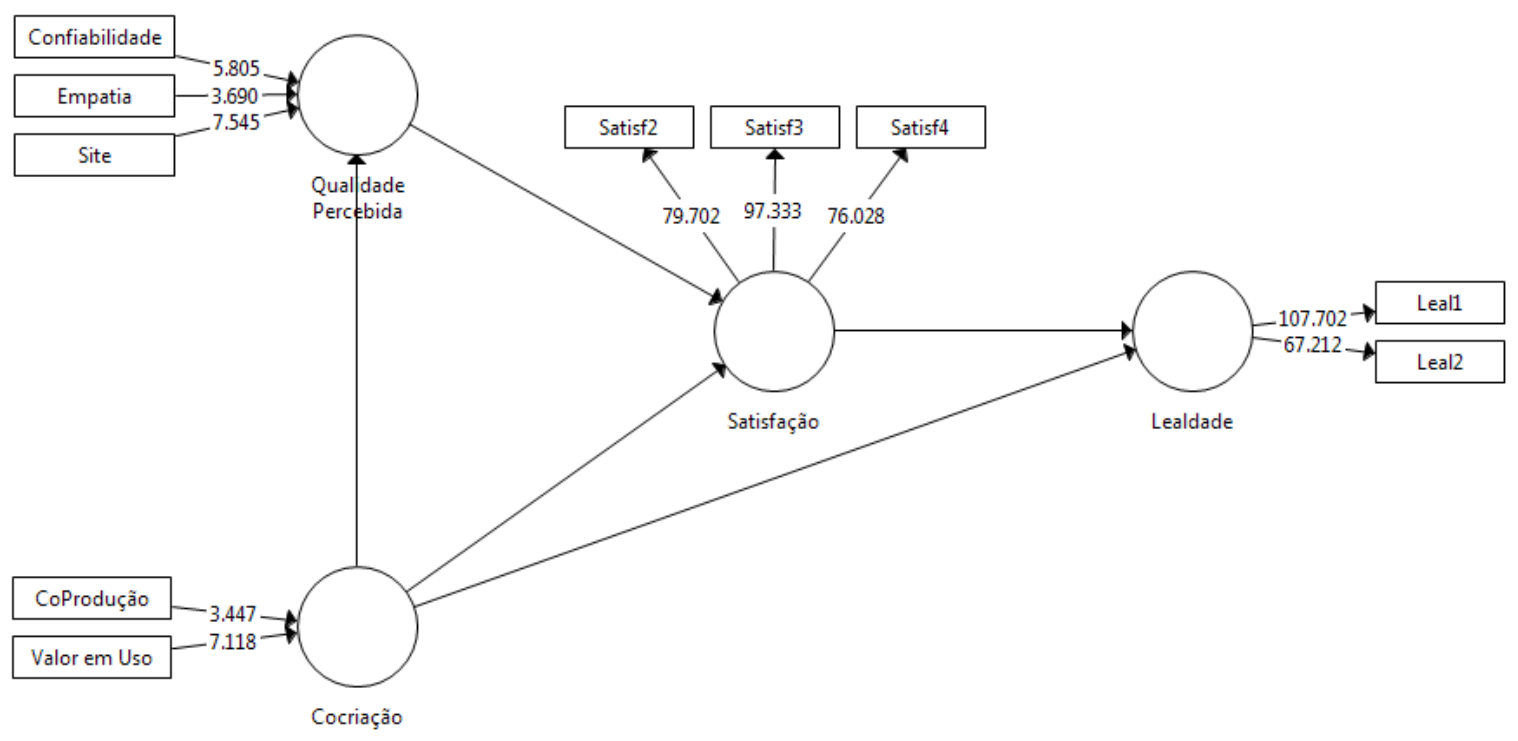

Figura 13. Avaliação do modelo de mensuração - execução final. $\mathrm{t}>1,96 . \mathrm{N}=400$

A próxima subseção traz os resultados para a análise do modelo estrutural.

\subsubsection{Modelo estrutural}

Com a confirmação do modelo de mensuração, seguiu-se para a avaliação do modelo estrutural, que apresenta as relações entre os construtos, sendo essencial para resposta aos objetivos propostos neste estudo e discussão apresentada no Capítulo 1.

Primeiramente foi avaliada a presença de multicolinearidade por meio do VIF, de forma similar ao realizado na Subseção 6.3.1. A Tabela 21 mostra que o critério de VIF $\leq 10$ é cumprido em todos os casos, seguindo-se, assim, para a avaliação das relações estruturais. 
Tabela 21

Avaliação de multicolinearidade (VIF) para o modelo proposto

\begin{tabular}{lc}
\hline \multicolumn{1}{c}{ Construtos } & VIF \\
\hline Cocriação -> Lealdade & 2,123 \\
Cocriação -> Qualidade Percebida & 1,000 \\
Cocriação -> Satisfação & 3,094 \\
Qualidade Percebida -> Satisfação & 3,094 \\
Satisfação -> Lealdade & 2,123 \\
\hline
\end{tabular}

Nota. Elaborado pela autora. $\mathrm{N}=400$

Para o teste de significância das relações estruturais foi realizado o procedimento de bootstrap com 5.000 reamostragens. Como indicado na Figura 14, todas as conexões foram significativas, confirmando, assim, as hipóteses levantadas neste estudo:

H1) Existe uma relação positiva entre cocriação de valor e qualidade percebida;

H2) Existe uma relação positiva entre qualidade percebida e satisfação;

H3) Existe uma relação positiva entre cocriação de valor e satisfação;

H4) Existe uma relação positiva entre satisfação e lealdade;

H5) Existe uma relação positiva entre cocriação de valor e lealdade. 


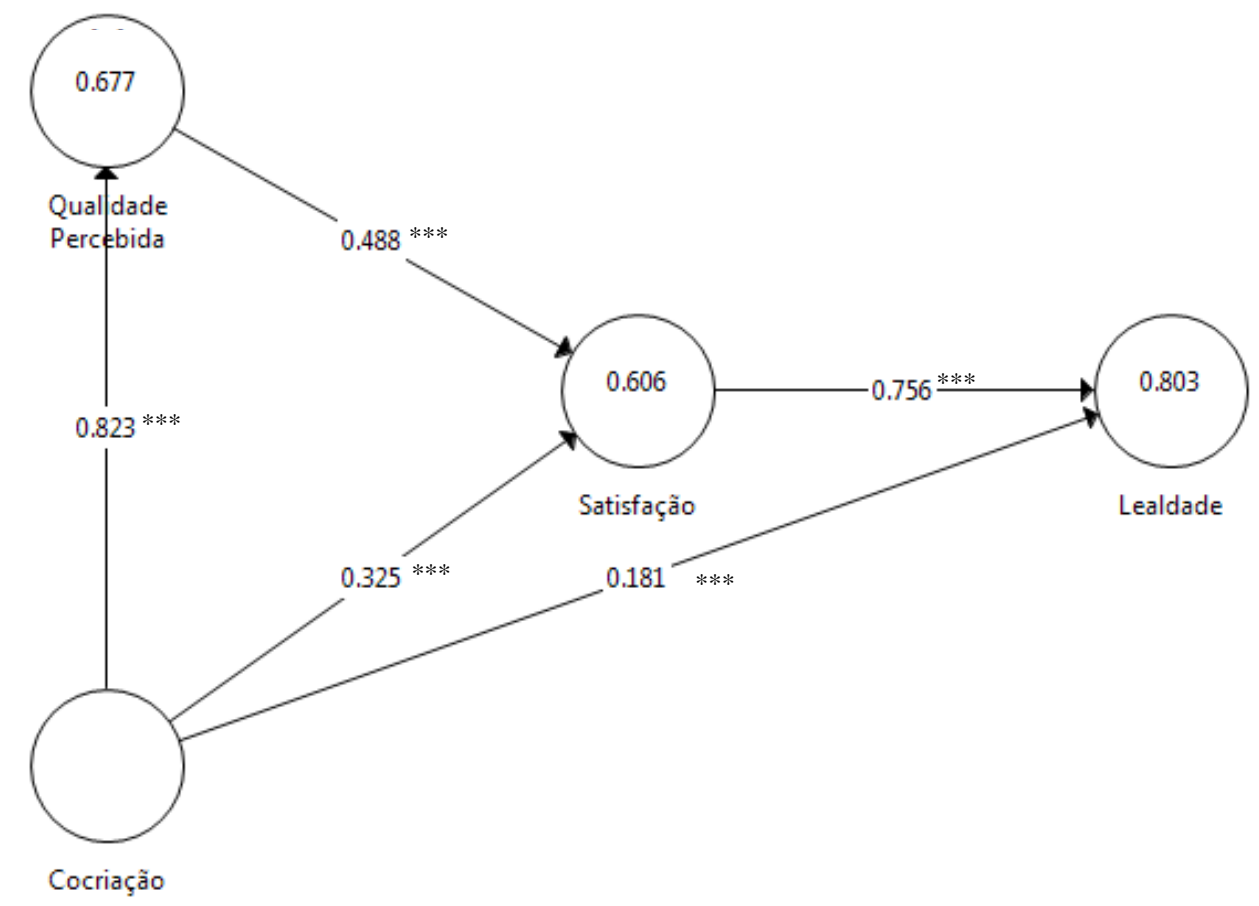

Figura 14. Análise do modelo estrutural. $* * * \mathrm{p} \leq 0,001 . \mathrm{N}=400$

Nos modelos de equações estruturais baseados em covariância, a avaliação da qualidade do ajuste do modelo ocorre por meio de estatísticas que comparam as distâncias das matrizes de covariância dos modelos teórico e empírico (Byrne, 2010; Hair et al., 2017). Uma vez que o modelo utilizado nesse trabalho utiliza o método dos mínimos quadrados parciais para as estimativas - baseando-se em variâncias para obtenção do modelo ótimo e não em diferenças de matrizes de covariâncias -, as mesmas estatísticas de qualidade de ajuste da modelagem baseada em covariância não podem ser aplicadas para avaliação da qualidade do ajuste.

Hair et al. (2017) apontam que há algumas propostas de estatística de qualidade de ajuste global para o método de PLS-SEM, mas que estão no início do desenvolvimento, não sendo assertivas. Assim, sugerem que as avaliações do modelo PLS-SEM sejam feitas por meio da significância dos coeficientes estruturais, os valores de $\mathrm{R}^{2}$, o tamanho do efeito $\mathrm{f}^{2}$, a relevância preditiva $\mathrm{Q}^{2}$ de Stone-Geisser e o tamanho do efeito $\mathrm{q}^{2}$.

Cohen (1988) aponta que, para as ciências sociais, o valor de $\mathrm{R}^{2}=0,02$ pode ser considerado pequeno, $\mathrm{R}^{2}=0,13$ é avaliado com médio e $\mathrm{R}^{2}=0,26$ é um efeito grande. Hair 
et al. (2017), por outro lado, assinalam que, apesar de os valores de referência dependerem da área de pesquisa, em geral, modelos de marketing podem seguir a regra de $\mathrm{R}^{2}=0,25$ é fraco, $\mathrm{R}^{2}=0,50$ é moderado e $\mathrm{R}^{2}=0,75$ é substancial.

$\mathrm{O}$ tamanho do efeito $\mathrm{f}^{2}$ permite avaliar qual a contribuição de cada variável latente para o ajuste do modelo. Cohen (1988) sugere que quando $\mathrm{f}^{2}$ é menor que 0,02, não há efeito da variável latente exógena, que quando $\mathrm{f}^{2}=0,02$, o efeito é pequeno, $\mathrm{f}^{2}=0,15$, o efeito é médio e $\mathrm{f}^{2}=0,35$ significa efeito grande.

A acurácia do modelo ajustado pode ser medida por meio da estatística $Q^{2}$ de StoneGeisser, sendo maior que zero quando o modelo está dentro do esperado. Para a obtenção deste valor, utiliza-se a técnica de blindfolding, algoritmo de simulação que consiste na retirada de um elemento da amostra de cada vez e tentativa de estimação deste elemento utilizando o modelo desenvolvido. A comparação entre o valor real e o estimado é usada no cálculo de $\mathrm{Q}^{2}$.

Por fim, o tamanho do efeito $\mathrm{q}^{2}$. Equivalentemente à $\mathrm{f}^{2}$, a medida $\mathrm{q}^{2}$ avalia a contribuição de cada variável latente para $\mathrm{Q}^{2}$. Valores de $\mathrm{q}^{2}$ de $0,02,0,15$ e 0,35 representam que um construto exógeno tem pequena, média ou grande relevância em um construto endógeno, respectivamente (Hair et al., 2017).

A Tabela 22 apresenta os valores de $\mathrm{R}^{2}$ e $\mathrm{Q}^{2}$ obtidos. Considerando os valores de referência apresentados anteriormente, é possível afirmar que o valor de $\mathrm{R}^{2}$ é substancial para Lealdade e moderado para Qualidade Percebida e Satisfação, indicando que a maior parte da variância dos construtos endógenos é explicada pelos demais construtos. Para as três dimensões, o valor de $\mathrm{Q}^{2}$ é maior do que zero, apontando relevância preditiva do modelo para estes construtos. 
Tabela 22

Valores de $R^{2}$ e $Q^{2}$ para variáveis latentes endógenas

\begin{tabular}{lcc}
\hline \multicolumn{1}{c}{ Construtos } & $\mathrm{R}^{2}$ & $\mathrm{Q}^{2}$ \\
\hline Lealdade & 0,802 & 0,661 \\
Qualidade Percebida & 0,676 & 0,488 \\
Satisfação & 0,604 & 0,495 \\
\hline
\end{tabular}

Nota. Elaborado pela autora. $\mathrm{N}=400$

Com o objetivo de entender o efeito que cada construto exerce na obtenção de $\mathrm{R}^{2}$ e $\mathrm{Q}^{2}$, foram avaliados os valores de $\mathrm{f}^{2} \mathrm{e}^{2}$ (Tabela 23).

Apesar de haver influência significativa de Cocriação de Valor em Lealdade (Figura 14), ela é pouco relevante para explicar a variabilidade deste construto, apresentando $\mathrm{f}^{2}$ e $\mathrm{q}^{2}$ pequenos. Seu efeito também é pequeno para Satisfação. Em contrapartida, a Cocriação de Valor mostra-se de grande relevância na determinação da Qualidade Percebida.

O construto de Satisfação possui grande efeito na Lealdade. A variabilidade da Satisfação é moderadamente explicada pela Qualidade Percebida.

Tabela 23

Valores dos efeitos $f^{2}$ e $q^{2}$

\begin{tabular}{lcc}
\hline \multicolumn{1}{c}{ Construtos } & $\mathrm{f}^{2}$ & $\mathrm{q}^{2}$ \\
\hline Cocriação -> Lealdade & 0,078 & 0,035 \\
Cocriação -> Qualidade Percebida & 2,094 & \\
Cocriação -> Satisfação & 0,087 & 0,059 \\
Qualidade Percebida -> Satisfação & 0,196 & 0,121 \\
Satisfação -> Lealdade & 1,363 & 0,398 \\
\hline
\end{tabular}

Nota. Elaborado pela autora. $\mathrm{N}=400$

Uma vez que os efeitos de Cocriação de Valor em Lealdade e Satisfação não se mostraram muito intensos, buscou-se, na literatura, uma dimensão que poderia ser utilizada como mediadora. 
Fullerton (2003) mostra que uma dimensão que represente o comprometimento influencia na Lealdade dos clientes, sendo, por vezes, indicada como mediadora da Satisfação para este construto (Mulyono, 2014). Não tendo sido encontrado nenhum estudo prévio relacionando Cocriação de Valor e Comprometimento, parece ser razoável supor que quando o cliente participa do processo de criação de valor, seu comprometimento seja alto. A questão que pode ser levantada nesta situação é se o efeito indireto da Cocriação de Valor em Lealdade (mediada por Comprometimento) é maior do que o efeito direto.

Embora tenha sido observada influência da Cocriação de Valor na Qualidade Percebida, o valor de $\mathrm{R}^{2}$ desta variável latente não se mostrou substancial considerando apenas a Cocriação de Valor. Mantovani (2012) apresentou a Imagem como sendo uma dimensão relevante para explicar a Qualidade Percebida. Dado que a Cocriação de Valor é um construto que reflete o interesse de participação do aluno e seu engajamento na criação de valor em conjunto com a faculdade, também parece ser razoável que quanto maior [melhor] a Imagem, maior será o interesse de envolvimento e participação do aluno no processo de construção do valor.

Entendendo ser possível propor um modelo alternativo - mais completo - ao proposto inicialmente, a próxima seção está inserida.

\subsection{Modelo Alternativo}

Conforme apontado nos últimos parágrafos, é interessante avaliar um modelo alternativo ao exibido no Capítulo 4. A contextualização dos elementos pertencentes a este novo modelo, bem como as hipóteses levantadas e seus resultados estão descritos de forma sucinta nesta seção.

A primeira etapa de apresentação do modelo concorrente refere-se à definição das novas dimensões incluídas. Fullerton (2003) discute o comprometimento como uma dimensão composta de uma vertente afetiva, cuja essência indica uma afeição emocional do consumidor com a empresa e outra prática, onde o apego existe por ser, de alguma forma, 
custoso mudar esse relacionamento. Usando estes conceitos, é possível entender o comprometimento como sendo um construto de segunda ordem, formativo nestas duas variáveis latentes.

Com relação à Imagem, de forma geral, pode-se dizer que representa as percepções ou impressões que o consumidor tem sobre a empresa. Mantovani (2012) utilizou-se de estudos prévios para criação de escala voltada para a educação a distância, considerada nesta pesquisa de forma adaptada.

As frases utilizadas na composição de cada um dos construtos podem ser observadas na Tabela 24, juntamente com suas estatísticas descritivas (mediana, média, desvio padrão, coeficiente de variação, assimetria e curtose). A maior concordância refere-se ao comprometimento do aluno com o curso a distância (média $=8,2$ ) e a menor - embora ainda alta - refere-se ao orgulho que o aluno sente ao estudar na instituição escolhida ( média $=7,0)$.

Tabela 24

Estatísticas descritivas dos itens de imagem e comprometimento

\begin{tabular}{|c|c|c|c|c|c|c|c|}
\hline & Construtos e respectivos itens & Med & Média & DP & $\mathrm{CV}$ & Assim & Curt \\
\hline \multirow{5}{*}{ 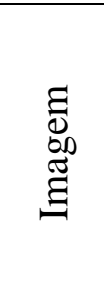 } & A faculdade é confiável & 9,0 & 8,1 & 2,3 & 0,3 & $-1,4$ & 1,4 \\
\hline & A faculdade é inovadora & 8,0 & 7,4 & 2,5 & 0,3 & $-0,9$ & 0,2 \\
\hline & $\begin{array}{l}\text { A faculdade serve de exemplo em educação a } \\
\text { distância no Brasil }\end{array}$ & 8,0 & 7,7 & 2,5 & 0,3 & $-1,2$ & 0,8 \\
\hline & A faculdade é sinônimo de qualidade de ensino & 8,0 & 7,5 & 2,4 & 0,3 & $-1,0$ & 0,5 \\
\hline & A faculdade apresenta boa reputação & 8,0 & 7,8 & 2,3 & 0,3 & $-1,2$ & 1,0 \\
\hline \multirow{3}{*}{ 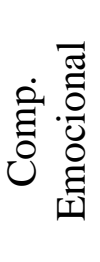 } & $\begin{array}{l}\text { Estou muito comprometido com meu curso a } \\
\text { distância }\end{array}$ & 9,0 & 8,2 & 2,4 & 0,3 & $-1,4$ & 1,8 \\
\hline & $\begin{array}{l}\text { Eu me sinto muito ligado à instituição do meu } \\
\text { curso a distância }\end{array}$ & 7,0 & 8,0 & 2,8 & 0,3 & $-1,3$ & 1,1 \\
\hline & $\begin{array}{l}\text { Eu sinto orgulho por poder estudar na instituição } \\
\text { do meu curso a distância }\end{array}$ & 8,0 & 7,0 & 2,7 & 0,4 & $-0,7$ & $-0,5$ \\
\hline \multirow{2}{*}{ 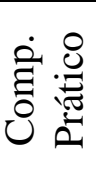 } & $\begin{array}{l}\text { Eu escolhi a instituição do meu curso a distância } \\
\text { por razões práticas }\end{array}$ & 9,0 & 7,4 & 2,2 & 0,3 & $-0,9$ & $-0,1$ \\
\hline & $\begin{array}{l}\text { Vale a pena continuar no curso, porque o custo de } \\
\text { mudança seria alto }\end{array}$ & 9,0 & 7,9 & 2,5 & 0,3 & $-1,2$ & 0,8 \\
\hline
\end{tabular}

Nota. Elaborado pela autora. $\mathrm{N}=400$ 
Estando definidos os conceitos utilizados para representar Comprometimento e Imagem, pode-se desenhar o modelo completo incorporando estes construtos ao modelo proposto anteriormente. Com o modelo constituído e após discussões levantadas nos últimos parágrafos da Seção 6.3, tem-se que as hipóteses acerca das relações entre dimensões (também ilustradas na Figura 15) são:

H6) Existe uma relação positiva entre imagem e qualidade percebida;

H7) Existe uma relação positiva entre imagem e cocriação de valor;

H8) Existe uma relação positiva entre satisfação e comprometimento;

H9) Existe uma relação positiva entre comprometimento e lealdade;

H10) Existe uma relação positiva entre cocriação de valor e comprometimento;

H11) O efeito indireto (mediado por comprometimento) entre satisfação e lealdade é maior do que seu efeito direto;

H12) O efeito indireto (mediado por comprometimento) entre cocriação de valor e lealdade é maior do que seu efeito direto.

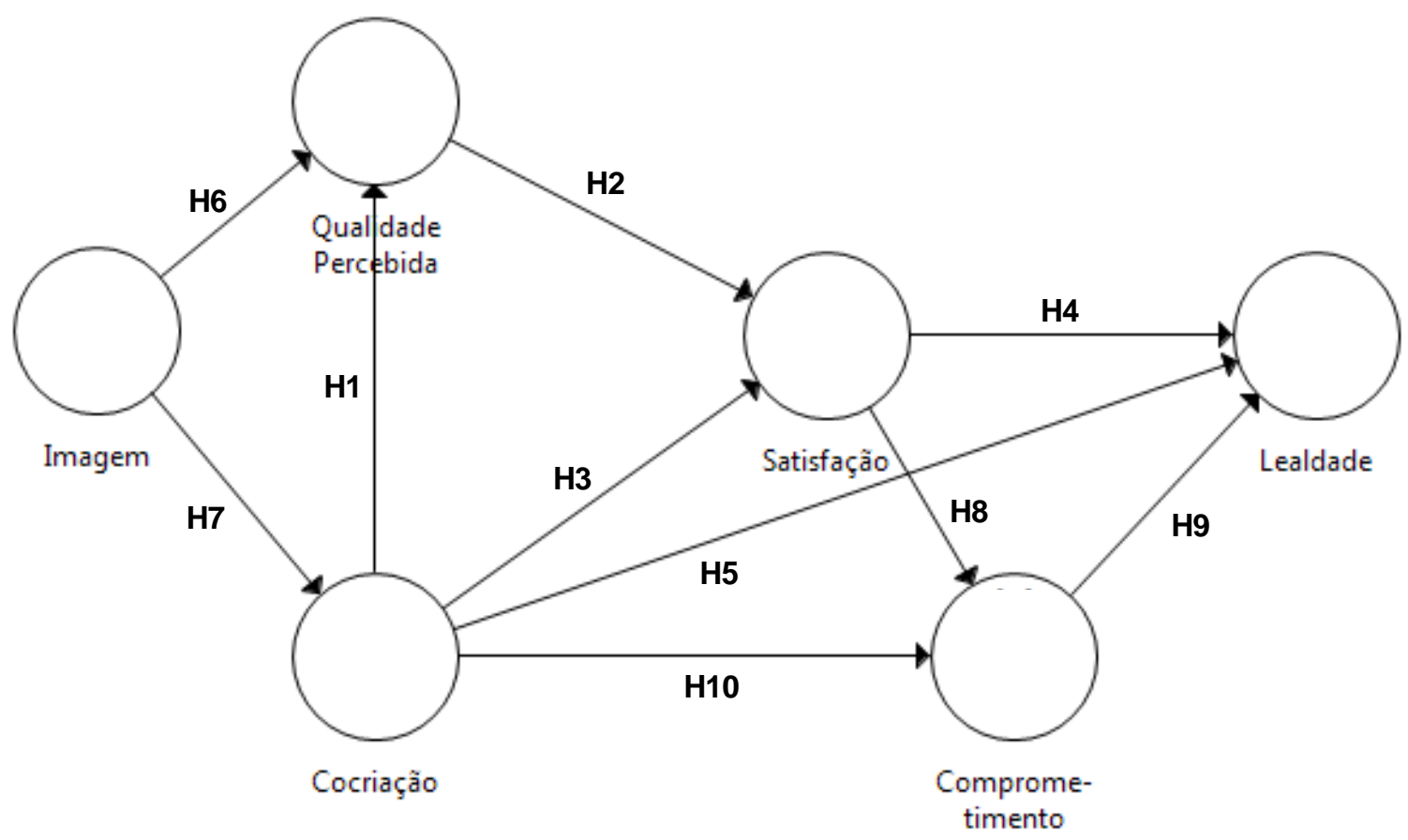

Figura 15. Modelo alternativo - visão macro. Hipóteses H1 a H5 descritas no Capítulo 4. $\mathrm{N}=400$ 
Assim como realizado na Seção 6.3, a análise dos resultados ocorreu por meio da técnica de equações estruturais, usando o software SmartPLS 3.2.6 em duas etapas: avaliação do modelo de mensuração e avaliação do modelo estrutural.

Na primeira etapa da análise, foram verificadas as validades discriminantes, convergentes e medidas de confiabilidade dos dados. Um resumo pode ser encontrado na Tabela 25.

Tabela 25

Medidas de validade convergente, discriminante e confiabilidade dos indicadores para o modelo alternativo

\begin{tabular}{|c|c|c|c|c|}
\hline & $\begin{array}{l}\text { Alpha de } \\
\text { Cronbach }\end{array}$ & $\begin{array}{c}\text { Confiabilidade } \\
\text { Composta }\end{array}$ & AVE & $\begin{array}{c}\text { Validade } \\
\text { Discriminante }^{\mathrm{a}}\end{array}$ \\
\hline Confiabilidade & 0,904 & 0,940 & 0,838 & Sim \\
\hline Empatia & 0,885 & 0,945 & 0,896 & Sim \\
\hline Site & 0,928 & 0,949 & 0,822 & Sim \\
\hline Conhecimento & 0,858 & 0,914 & 0,779 & Sim \\
\hline Interação & 0,895 & 0,935 & 0,827 & Sim \\
\hline Transparência & 0,859 & 0,914 & 0,781 & Sim \\
\hline Experiência & 0,870 & 0,920 & 0,794 & Sim \\
\hline Personalização & 0,808 & 0,886 & 0,723 & Sim \\
\hline Relacionamento & 0,920 & 0,944 & 0,807 & Sim \\
\hline Satisfação & 0,925 & 0,952 & 0,870 & Sim \\
\hline Lealdade & 0,845 & 0,928 & 0,866 & Sim \\
\hline Imagem & 0,959 & 0,968 & 0,860 & Sim \\
\hline Comprometimento Emocional & 0,894 & 0,934 & 0,826 & Sim \\
\hline Comprometimento Prático & 0,649 & 0,850 & 0,740 & Sim \\
\hline
\end{tabular}

Nota. Elaborado pela autora. ${ }^{a}$ Validade Discriminante verificada por meio de critério de Fornell-Larcker, avaliação das cargas fatoriais e estatística HTMT. $\mathrm{N}=400$

Observando redundância no construto de Imagem, adotou-se o mesmo procedimento apontado anteriormente, desconsiderando-se as frases com maior correlação entre as demais e que pouco [menos] afetavam o valor do alpha de Cronbach.

O valor de alpha de Cronbach para o pilar prático do comprometimento não satisfaz o critério estabelecido porém, Hair et al. (2017) ressaltam que ele é muito sensível ao 
número de variáveis do construto, sendo possível considerá-lo admissível quando está entre 0,6 e 0,7; no presente estudo, ele está no limiar dessa medida $(0,65)$ e apresenta confiabilidade composta (CC) acima do valor de referência de 0,7 , sendo aceita a condição de confiabilidade do construto.

Com relação ao Comprometimento, foi utilizada mesma metodologia - two stages realizada para a Qualidade Percebida para que as medidas de avaliação pudessem ser analisadas no modelo como um todo. A Figura 16 contempla as imagens referentes a este processo.

(a)

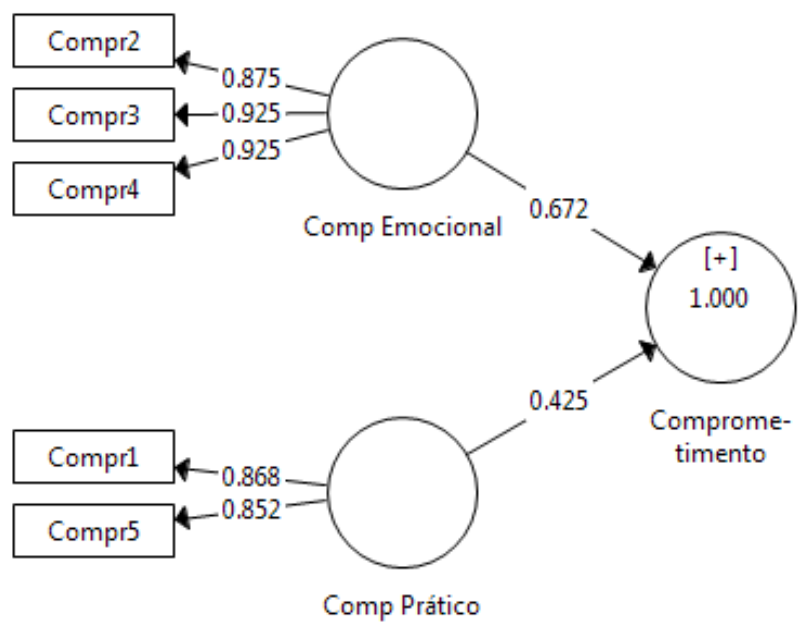

(b)

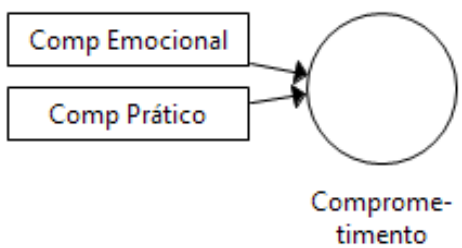

Figura 16. Modelo de mensuração para comprometimento. (a) Comprometimento como construto de segunda ordem. (b) Comprometimento como construto de primeira ordem. $\mathrm{N}=400$

Por fim, com o modelo de mensuração validado, tem-se o modelo completo para a avaliação das relações estruturais (Figura 17, já apresentando o Comprometimento como construto de primeira ordem). 


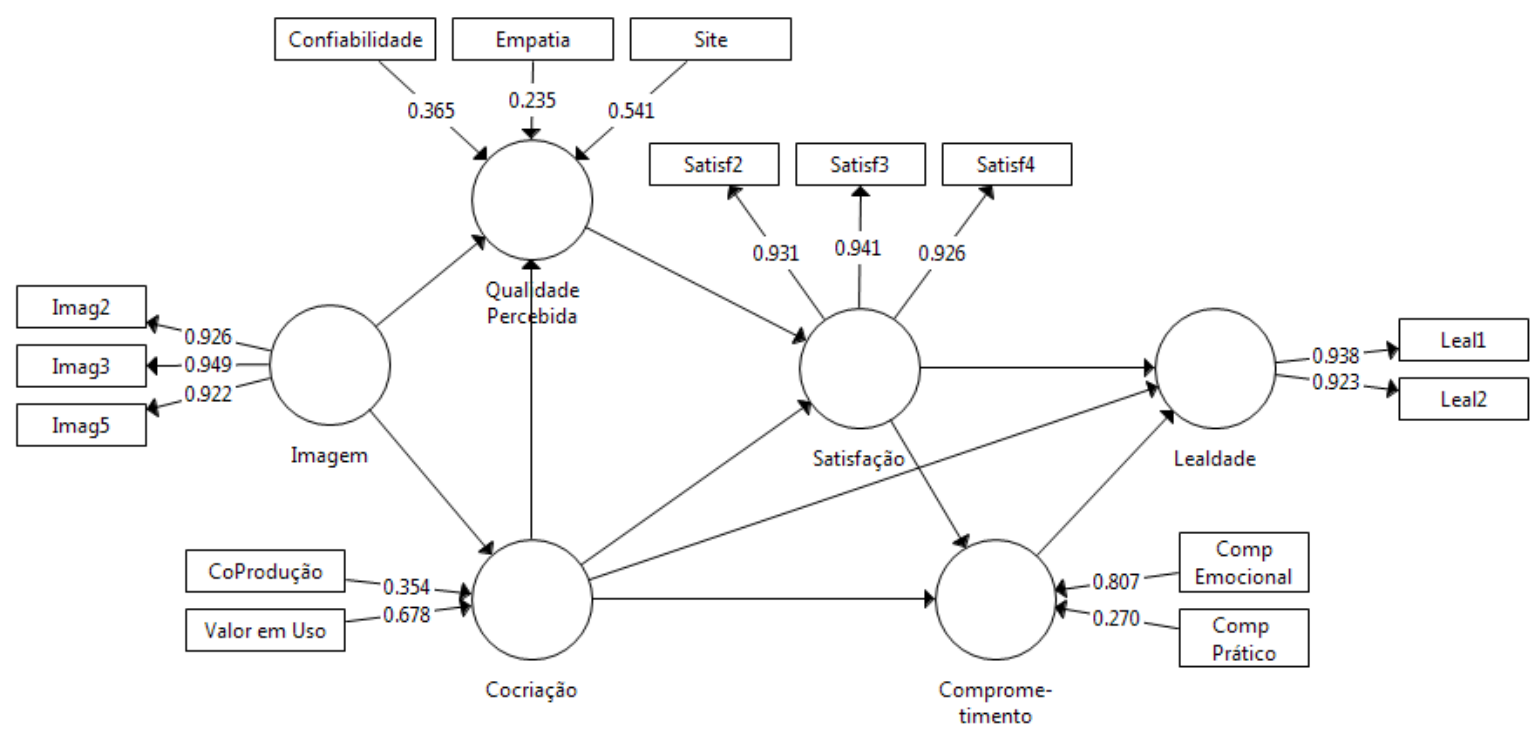

Figura 17. Avaliação do modelo de mensuração alternativo. $\mathrm{t}>1,96 . \mathrm{N}=400$

Para a avaliação do modelo estrutural, iniciou-se pela análise de multicolinearidade dos dados por meio dos fatores de inflação de variância (VIF), que como podem ser vistos na Tabela 26, se apresentam menores do que 10.

Tabela 26

Avaliação de multicolinearidade (VIF) para modelo alternativo

\begin{tabular}{lc}
\hline \multicolumn{1}{c}{ Construtos } & VIF \\
\hline Cocriação -> Lealdade & 2,424 \\
Cocriação -> Qualidade Percebida & 3,285 \\
Cocriação -> Satisfação & 3,030 \\
Cocriação -> Comprometimento & 2,122 \\
Qualidade Percebida -> Satisfação & 3,030 \\
Satisfação -> Lealdade & 4,641 \\
Satisfação -> Comprometimento & 2,122 \\
Imagem -> Cocriação & 1,000 \\
Imagem -> Qualidade Percebida & 3,285 \\
Comprometimento -> Lealdade & 5,085 \\
\hline
\end{tabular}

Nota. Elaborado pela autora. $\mathrm{N}=400$

Com a inexistência de multicolinearidade confirmada, o próximo passo é quantificar as relações e entender o efeito de cada construto na variabilidade total explicada pelo modelo. 
A Figura 18 traz os resultados obtidos por meio do método de bootstrap com 5.000 reamostragens.

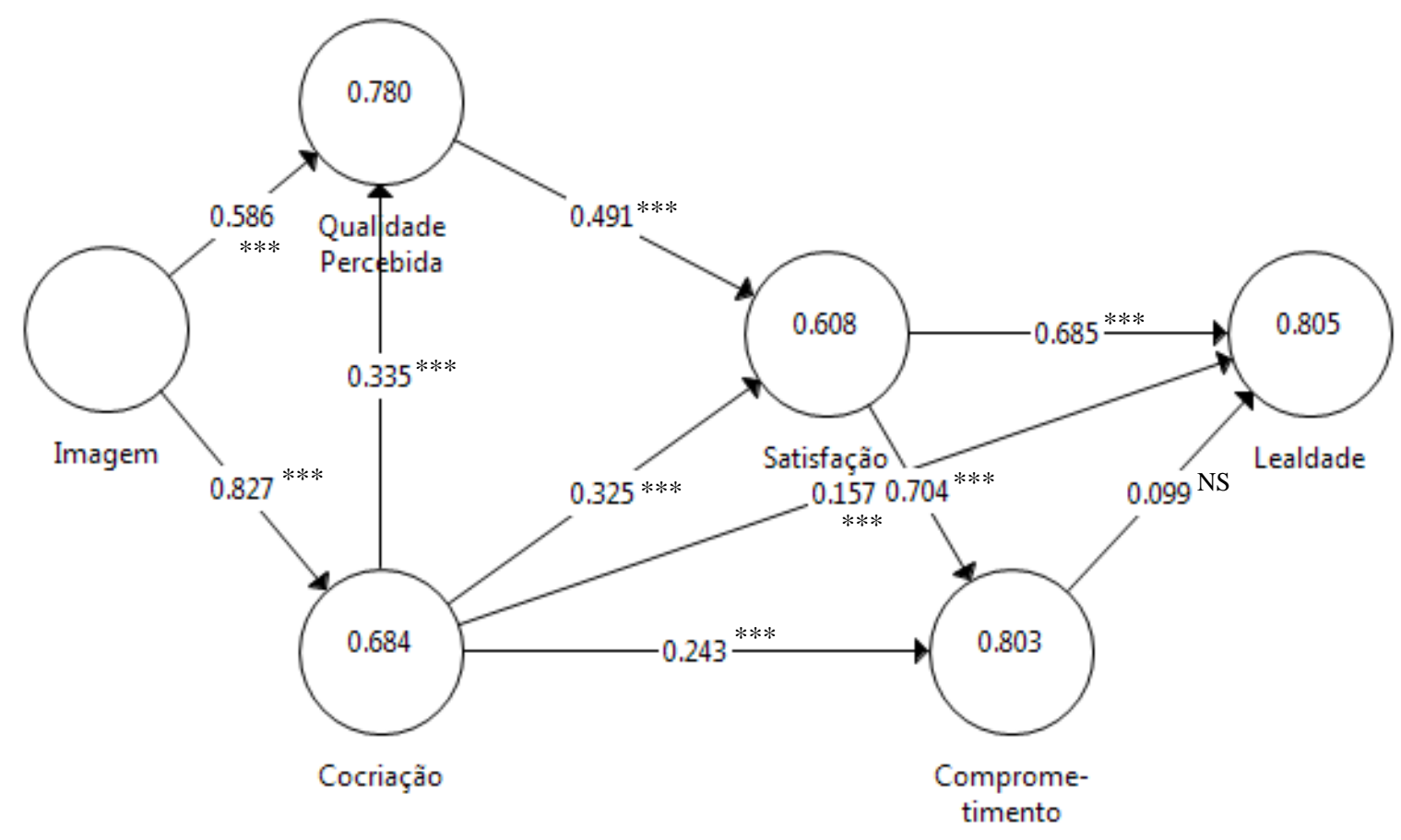

Figura 18. Análise do modelo estrutural alternativo. ${ }^{* * *} \mathrm{p} \leq 0,001{ }^{\mathrm{NS}}$ Não Significativo. $\mathrm{N}=400$

Usando como ponto de partida as hipóteses levantadas, tem-se a confirmação de que a imagem apresenta relação positiva tanto com qualidade percebida quanto com cocriação de valor (H6 e H7) e as hipóteses H8 e H10 também são sustentadas com as relações positivas entre satisfação e comprometimento e entre cocriação de valor e comprometimento. No entanto, a relação entre comprometimento e lealdade não se mostrou significativa. Este resultado contraria o que se esperava, sendo motivo de uma investigação mais detalhada.

Quando se examina apenas a relação entre comprometimento e lealdade, de forma direta, ela é significativa e positiva. O mesmo ocorre quando observados os efeitos diretos entre satisfação e lealdade e entre cocriação de valor e lealdade (Figura 19). 
(a)

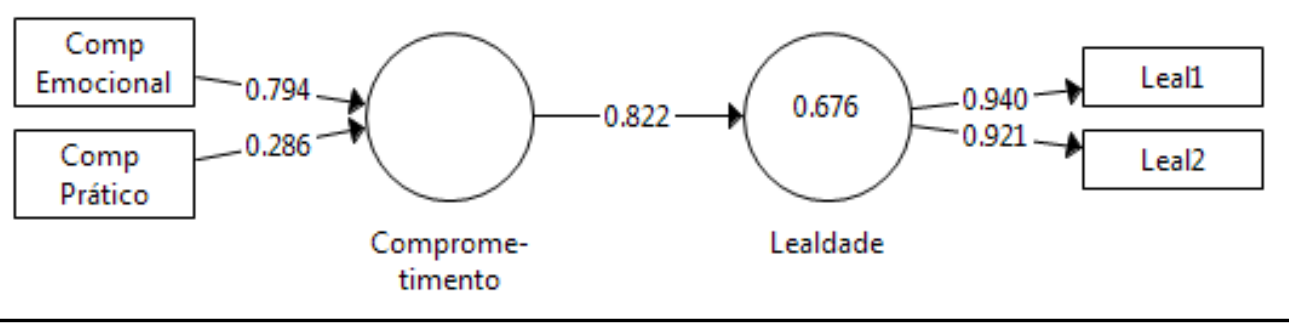

(b)

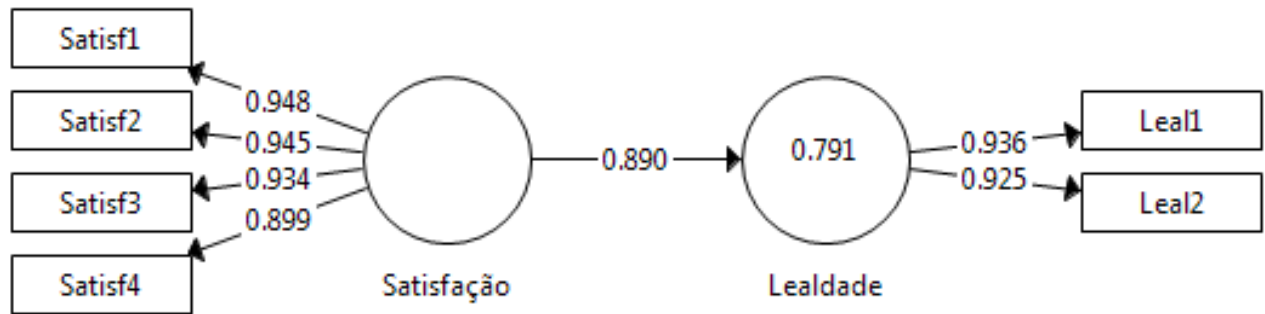

(c)

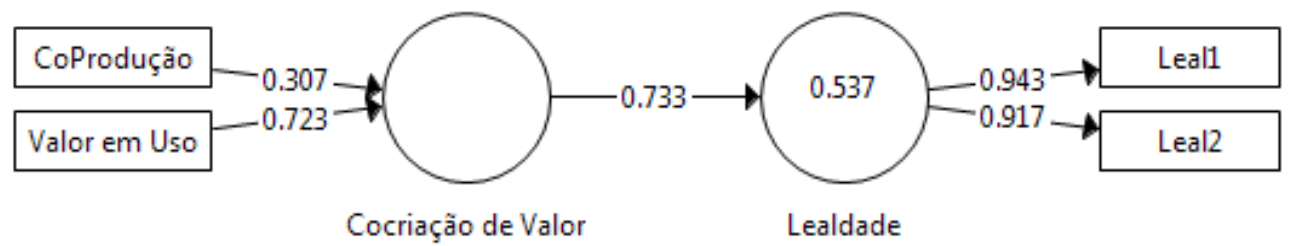

Figura 19. Lealdade como construto consequente. (a) Comprometimento e Lealdade. (b) Satisfação e Lealdade. (c) Cocriação de Valor e Lealdade. $N=400$

Na primeira edição de seu livro, Hair et al. (2017) sugerem a medida de Variance Accounted For (VAF) para a avaliação do grau de mediação, apontando que quando o efeito indireto representa menos de $20 \%$ do efeito total não há mediação, quando este valor encontra-se entre $20 \%$ e $80 \%$, a mediação é parcial e quando o efeito indireto é maior do que $80 \%$ do efeito total, a mediação é completa.

Observando comprometimento como mediadora entre cocriação de valor e lealdade, temse que todas as relações são significativas e o VAF é de $65 \%$, representando uma mediação parcial e, como hipótese H12 levantada, o efeito indireto da cocriação de valor mediada por comprometimento $(0,476)$ é maior do que o efeito direto $(0,256)$, conforme ilustrado na Figura 20. 


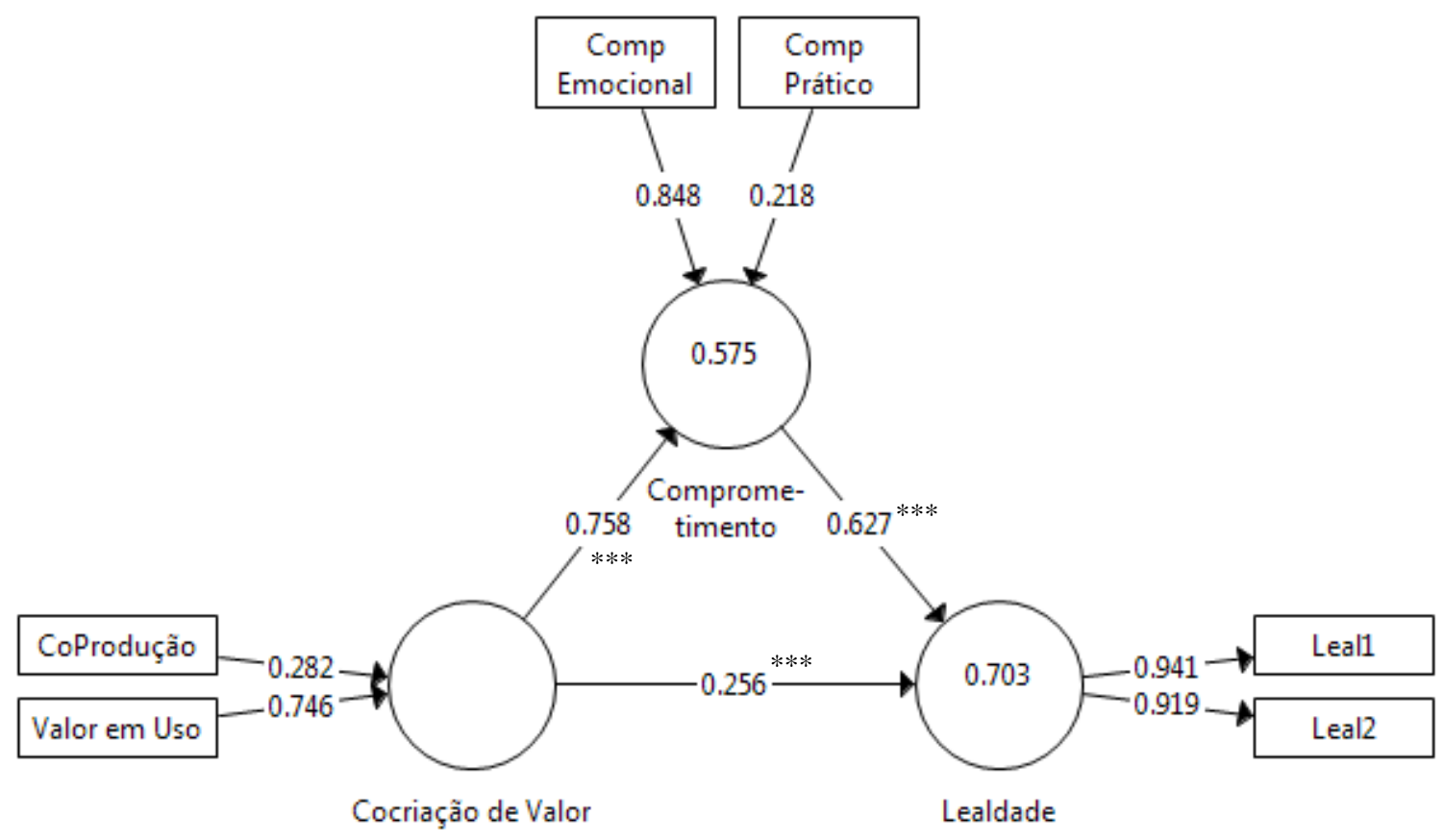

Figura 20. Modelo estrutural cocriação de valor e lealdade, mediado por comprometimento. $* * * \mathrm{p} \leq 0,001 . \mathrm{N}=400$

Fazendo a mesma análise para a satisfação em relação à mediação do comprometimento em seu efeito na lealdade - vista por Mulyono (2014) como única forma de relacionamento entre satisfação e lealdade - observa-se um efeito pouco significativo entre comprometimento e lealdade (Figura 21). Neste caso, o efeito direto representa mais de $82 \%$ do efeito total, indicando uma não mediação. 


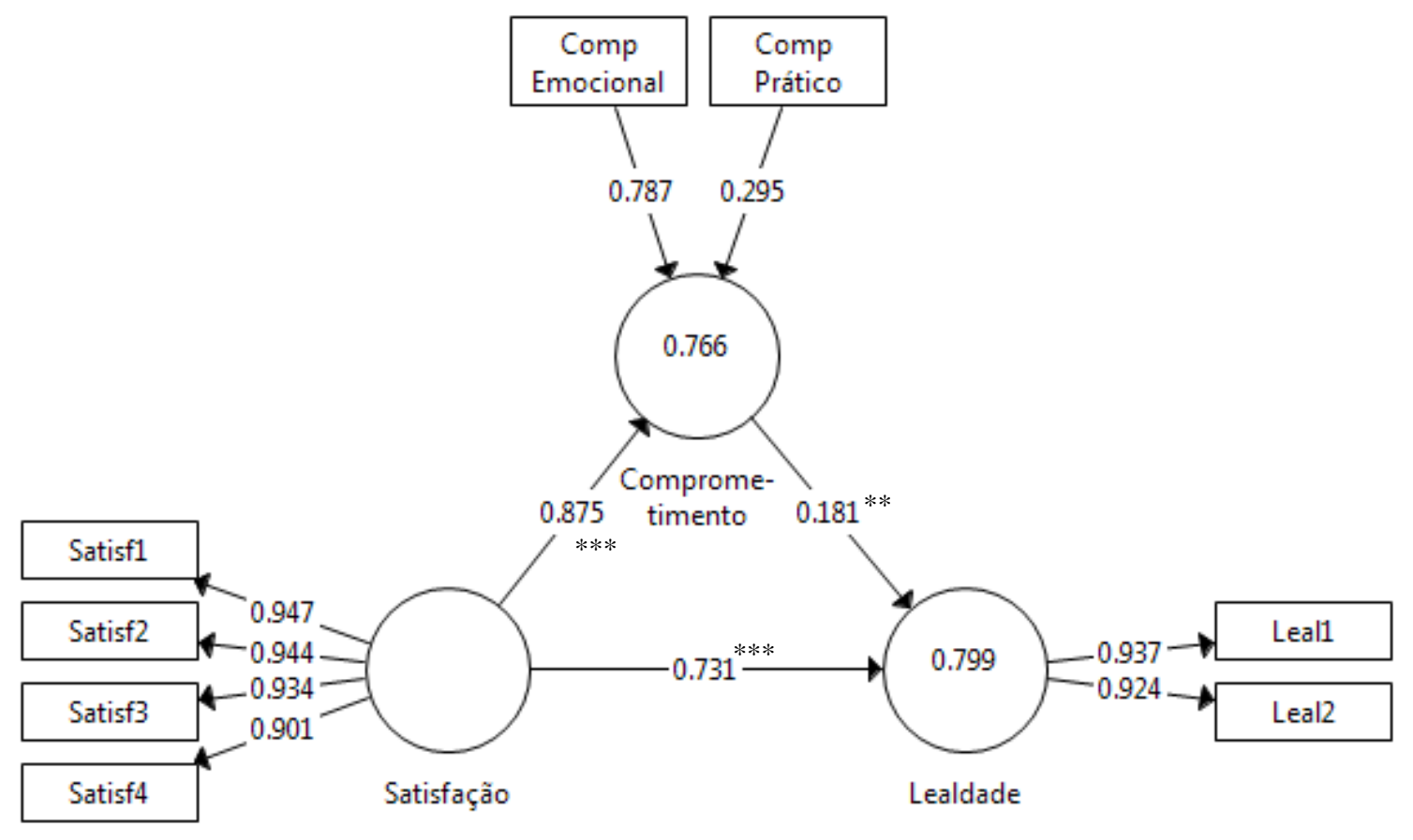

Figura 21. Modelo estrutural satisfação e lealdade, mediado por comprometimento. $* * * \mathrm{p} \leq 0,001 \mid * * \mathrm{p} \leq 0,05 . \mathrm{N}=400$

Este último resultado indica a não confirmação da hipótese H11, sendo o efeito direto de satisfação em lealdade maior do que o mediado por comprometimento.

Embora pareçam contraditórios os resultados obtidos antes da investigação dos efeitos da mediação para cocriação de valor e satisfação separadamente e aqueles obtidos individualmente, eles não são. A técnica de equações estruturais com estimação por variância, usando mínimos quadrados parciais (PLS-SEM) apresenta, como principal objetivo, otimizar a previsão de uma variável latente por meio de um conjunto de outras variáveis e suas relações. Neste sentido, tem-se que a lealdade - variável final a ter sua previsão realizada - já é suficientemente explicada diretamente pela satisfação, anulando o efeito indireto de cocriação de valor em lealdade.

Do ponto de vista dos objetivos primários deste estudo, pode-se considerar como modelo final estimado aquele representado na Figura 22, com a inclusão da Imagem, mas exclusão do comprometimento por não indicar ganho na estimativa da lealdade. 


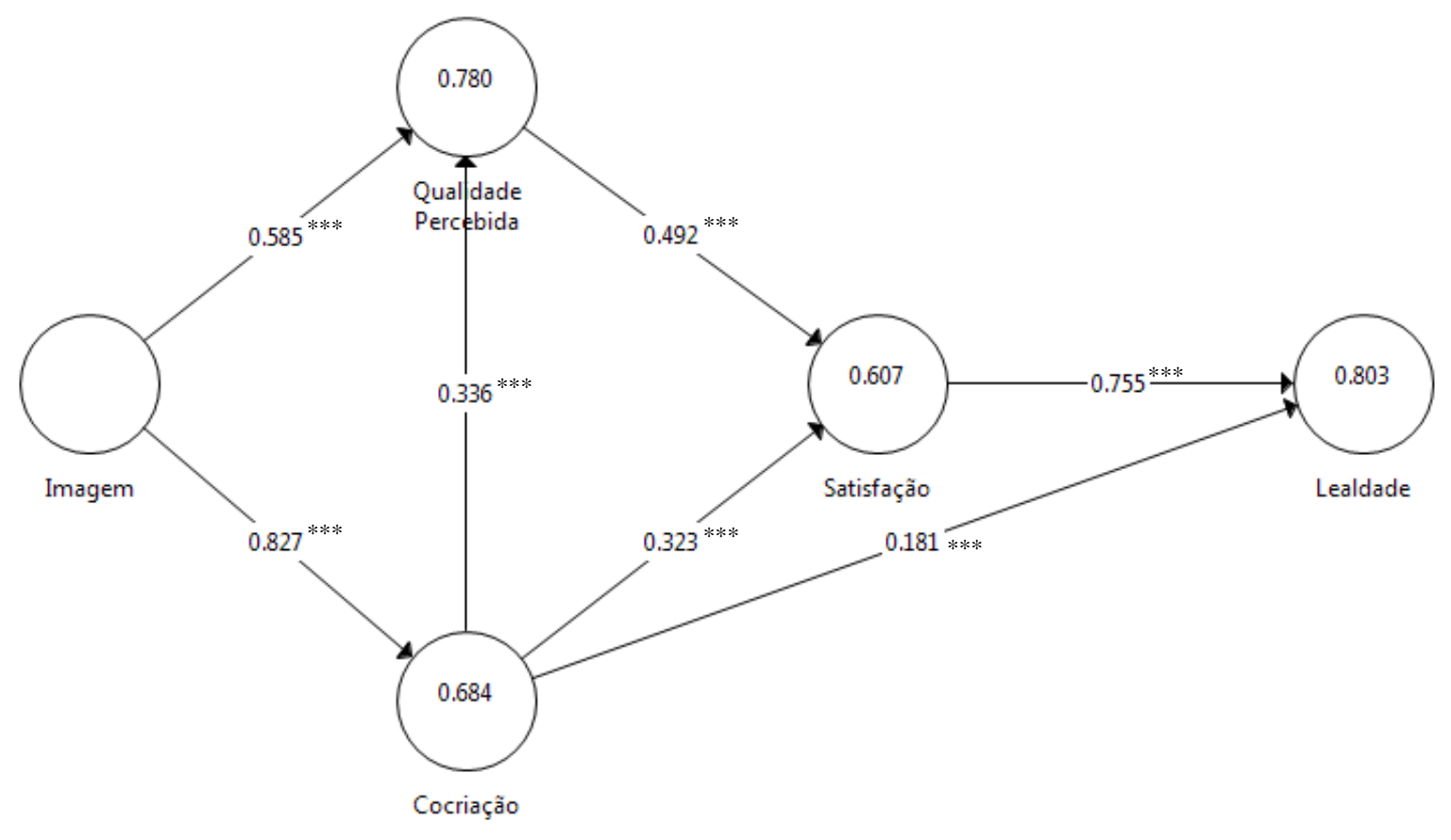

Figura 22. Modelo estrutural final. $* * * \mathrm{p} \leq 0,001 . \mathrm{N}=400$

Estatísticas finais de qualidade do modelo, juntamente com a informação dos efeitos totais, podem ser encontradas na Tabela 27. Comparando os resultados com aqueles obtidos no modelo anterior, observa-se uma leve melhora na predição e acurácia dos construtos com a inclusão de Imagem. Cocriação de Valor, porém, ainda apresenta efeito mediano nos construtos de Satisfação e Lealdade.

Tabela 27

Medidas de avaliação do modelo estrutural alternativo

\begin{tabular}{lcccc}
\hline \multicolumn{1}{c}{ Construtos } & $\mathrm{R}^{2}$ & $\mathrm{Q}^{2}$ & $\mathrm{f}^{2}$ & $\mathrm{q}^{2}$ \\
\hline Cocriação de Valor & 0,684 & 0,606 & & \\
Lealdade & 0,803 & 0,661 & & \\
Qualidade Percebida & 0,780 & 0,551 & & \\
Satisfação & 0,607 & 0,496 & & \\
\hline Cocriação -> Lealdade & & & 0,079 & 0,034 \\
Cocriação -> Qualidade Percebida & & 0,162 & 0,067 \\
Cocriação -> Satisfação & & 0,087 & 0,054 \\
Imagem -> Cocriação & & 2,168 & \\
Imagem -> Qualidade Percebida & & & 0,490 & 0,140 \\
Qualidade Percebida -> Satisfação & & & 0,203 & 0,125 \\
Satisfação -> Lealdade & & & 1,366 & 0,466 \\
\hline
\end{tabular}

Nota. Elaborado pela autora. $\mathrm{N}=400$ 
Com o modelo final estabelecido, tem-se que a última etapa para que todos os objetivos apresentados na Seção 1.1 estejam contemplados no trabalho é a verificação do comportamento do modelo, em especial as relações (efeitos) encontradas segundo perfil do aluno respondente. A próxima seção, última deste capítulo de resultados, detalha os principais achados desta análise.

\subsection{Diferenças por Tipologia de Aluno}

O objetivo específico (e) indicado na Seção 1.1 é analisar a intensidade das relações entre dimensões considerando características dos estudantes e cursos frequentados por estes.

Durante etapa qualitativa da pesquisa, os três entrevistados disseram acreditar, levando em conta os problemas relatados e soluções adotadas nos polos de suas faculdades durante o dia-a-dia, que a forma de lidar com a satisfação e a lealdade difere segundo as características regionais do aluno (local de moradia), etapa do curso (início ou fim do curso), área de estudo e tipologia do curso. Não é possível, porém, tentar prever, de antemão, onde e como as diferenças ocorrerão.

Além dos pontos levantados pelos entrevistados, acredita-se que a idade do aluno, além da posse de filhos, pode trazer alguma diferença em função de possíveis expectativas, propósitos e facilidade (ou dificuldade) de pagamento existentes.

Para que fosse possível avaliar as diferenças de cada uma das tipologias de alunos, foi executada análise multigrupo (PLS-MGA), que consiste em separar os dados nos grupos de interesse e comparar os coeficientes do modelo estrutural. Para todas as execuções, foram avaliadas as validades discriminantes, convergentes e medidas de confiabilidade como realizado anteriormente, sem que houvesse nenhuma situação de não conformidade.

É importante ressaltar que o tamanho da amostra de cada grupo deve manter um valor mínimo para que se possa afirmar que as diferenças encontradas não são devidas ao baixo poder do teste, sendo, por vezes, necessária a junção de categorias. Na Seção 5.3 foram 
discutidos detalhes acerca deste tema, com a conclusão de uma amostra ideal de, pelo menos, 138 casos se considerado efeito médio, poder do teste de $95 \%$ e significância de $5 \%$ (cálculo realizado via software G*Power) ou 92 casos para um poder de $80 \%$.

Com base nas quantidades de respondentes presentes na amostra (ver Seção 6.2), foram considerados os seguintes agrupamentos para avaliação do modelo estrutural:

- Localização do polo: Sudeste/Nordeste | Demais;

- Ciclo do aluno: Calouro ( $1^{\circ}$ ano $) \mid$ Veterano/Formado;

- Área de conhecimento: Exatas/Biológicas |Humanas;

- Tipologia do curso: Licenciatura | Bacharelado/Tecnólogo;

- Faixa etária: Até 29 anos | 30 anos ou mais;

- Posse de filhos: Sim | Não.

Os resultados das análises comparativas são apresentados na Tabela 28. 
Tabela 28

Comparação das relações estruturais segundo grupos de interesse

\begin{tabular}{|c|c|c|c|c|c|c|c|c|}
\hline & & 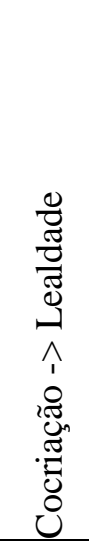 & 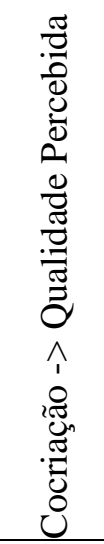 & 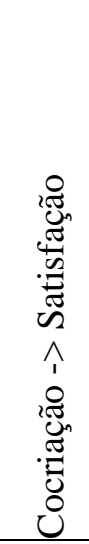 & 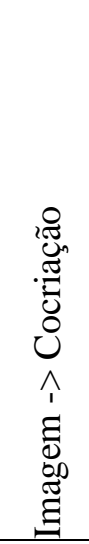 & 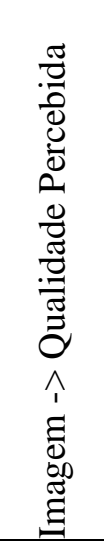 & 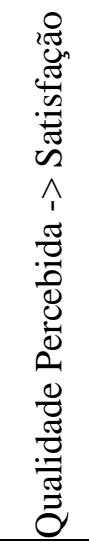 & 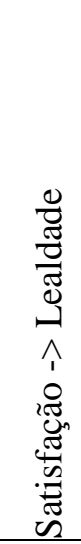 \\
\hline \multirow{3}{*}{$\begin{array}{l}\text { Localização do } \\
\text { polo }\end{array}$} & SE/NE & 0,21 & 0,39 & 0,44 & 0,86 & 0,49 & 0,40 & 0,74 \\
\hline & Demais & 0,17 & 0,34 & 0,24 & 0,81 & 0,61 & 0,56 & 0,76 \\
\hline & Há diferença? & Não & Não & $*$ & Não & Não & Não & Não \\
\hline \multirow{3}{*}{$\begin{array}{c}\text { Área de } \\
\text { conhecimento }\end{array}$} & Exatas/Biológicas & 0,25 & 0,26 & 0,32 & 0,86 & 0,65 & 0,46 & 0,68 \\
\hline & Humanas & 0,10 & 0,40 & 0,31 & 0,79 & 0,53 & 0,54 & 0,84 \\
\hline & Há diferença? & $*$ & Não & Não & $* *$ & Não & Não & Não \\
\hline \multirow{3}{*}{ Ciclo do aluno } & Calouro (1o ano) & 0,14 & 0,32 & 0,37 & 0,81 & 0,61 & 0,49 & 0,80 \\
\hline & Veterano/Formado & 0,23 & 0,28 & 0,31 & 0,85 & 0,63 & 0,48 & 0,69 \\
\hline & Há diferença? & Não & Não & Não & Não & Não & Não & Não \\
\hline \multirow{3}{*}{$\begin{array}{l}\text { Tipologia do } \\
\text { curso }\end{array}$} & Licenciatura & 0,20 & 0,28 & 0,31 & 0,85 & 0,61 & 0,55 & 0,73 \\
\hline & Bacharelado/Tecnólogo & 0,17 & 0,39 & 0,33 & 0,81 & 0,56 & 0,45 & 0,77 \\
\hline & Há diferença? & Não & Não & Não & Não & Não & Não & Não \\
\hline \multirow{3}{*}{ Idade } & Até 29 anos & 0,15 & 0,46 & 0,49 & 0,80 & 0,45 & 0,37 & 0,78 \\
\hline & 30 anos ou mais & 0,18 & 0,20 & 0,19 & 0,86 & 0,72 & 0,62 & 0,75 \\
\hline & Há diferença? & Não & $* * *$ & $* * *$ & Não & Não & Não & Não \\
\hline \multirow{3}{*}{ Posse de filhos } & Sim & 0,22 & 0,26 & 0,20 & 0,83 & 0,64 & 0,60 & 0,69 \\
\hline & Não & 0,15 & 0,40 & 0,42 & 0,84 & 0,54 & 0,41 & 0,81 \\
\hline & Há diferença? & Não & Não & Não & Não & Não & Não & Não \\
\hline
\end{tabular}

De forma geral, não são observadas diferenças significativas quando analisadas as relações estruturais para subgrupos da amostra, porém, alguns resultados interessantes podem ser ressaltados: 
Regionalidade (localização do polo)

A relevância da cocriação de valor na explicação da satisfação apresenta maior intensidade nos polos presentes no Sudeste ou Nordeste frente às demais regiões $(p \leq 0,1)$.

\section{Área de conhecimento}

Para alunos pertencentes aos cursos da área de Humanas, a lealdade é primordialmente regida pela satisfação com o curso e, sendo a cocriação de valor de menor relevância para identificar a lealdade do aluno do que nos cursos de Exatas ou Biológicas ( $p \leq 0,1)$.

Alunos de Exatas ou Biológicas apresentam maior interesse na participação da criação do valor quanto melhor a percepção de imagem da faculdade quando comparados com alunos de Humanas. Apesar de estes últimos também entenderem a imagem como relevante para o engajamento na criação de valor, sua intensidade é menor $(\mathrm{p} \leq 0,05)$.

\section{Faixa etária}

Para o grupo dos alunos mais novos, pertencentes à chamada Geração Y, primeiros indivíduos que cresceram com a presença de Internet, a cocriação de valor apresenta maior peso na explicação da qualidade percebida e da satisfação do que para alunos de outras idades $(\mathrm{p} \leq 0,01)$.

Apesar de não ter apresentado diferença significativa, é possível dizer que há indícios de que, para os alunos mais velhos, a imagem da faculdade tem maior interferência em sua percepção de qualidade do que para os mais jovens. 
Com a avaliação do modelo segundo tipologia do aluno, tem-se o cumprimento dos objetivos propostos inicialmente. O próximo capítulo sintetiza todos os pontos apresentados ao longo do texto, além de indicar limitações observadas e sugestões de estudos futuros de forma a dar continuidade na exploração do tema de pesquisa apresentado. 


\section{CONSIDERAÇÕES FINAIS}

A pergunta problema que desencadeou esta pesquisa referia-se ao levantamento dos aspectos da cocriação de valor considerados determinantes no impacto dos elementos de qualidade percebida, satisfação e lealdade, com foco na educação a distância. Como resposta, foi composta uma dimensão que englobasse os aspectos teóricos da cocriação de valor e desenvolvidas hipóteses acerca das relações entre as dimensões de interesse.

No que tange a cocriação de valor, os dois principais aspectos para a sua caracterização dizem respeito à coprodução e ao valor obtido durante o uso do serviço, sendo especialmente relevante a identificação do aluno com a transparência da instituição e seu relacionamento com a própria faculdade, seus colegas de curso e envolvimento de amigos e familiares.

No convite para as respostas, foi disponibilizado endereço de $e$-mail para o caso de dúvidas ou solicitações de mais informações sobre a pesquisa realizada (Apêndice B). Dentre as mensagens enviadas pelos alunos, algumas foram sobre questionamentos e pedidos de confirmação sobre a validade da pesquisa e outras foram de alunos que quiseram relatar suas experiências com o curso a distância, sendo muito interessante notar a importância do curso na vida das pessoas.

Embora não tenha sido este o propósito deste estudo, os relatos vão ao encontro do apontado na fase qualitativa da pesquisa e trazem uma visão mais ampla sobre o EaD. Um estudante de licenciatura em educação física disse ser sua primeira experiência com a modalidade $\mathrm{EaD}$, destacando que, afinal, está conseguindo realizar o sonho de obter diploma de curso superior e aponta a modalidade como um avanço para a melhoria da educação nacional. Já outro aluno ressaltou, como ponto positivo da modalidade, a adequação do curso à vida do estudante. E outra, que está em seu segundo curso a distância, acredita ser o EaD uma boa oportunidade para todos que buscam uma chance de estudar. 
Alguns alunos também apontaram suas frustrações com o curso. As principais delas referem-se à necessidade de autodisciplina por parte do aluno e à falta de interesse que sentem pela faculdade em seu aprendizado. Nos resultados da pesquisa, estes pontos foram capturados nas [menores] notas relativas às frases que tratavam do reconhecimento do aluno no mercado de trabalho apenas em função do nome da instituição ou aquelas com viés de individualização do ensino, como a de atendimento às necessidades individuais ou a que questiona se a faculdade é aberta para ideias ou sugestões.

Tendo sido visto como algo relevante especialmente para a percepção de qualidade, a instituição deve conseguir mesclar a facilidade - e massificação - do acesso, sem perder o foco da importância de perceber o aluno como indivíduo único, com características únicas.

Com relação às hipóteses levantadas para a avaliação dos objetivos específicos propostos, com exceção da que apontava o comprometimento como mediadora para a relação entre satisfação e lealdade, todas foram confirmadas, indicando que a participação do estudante na criação de valor tem efeito não apenas na percepção de qualidade, como dito anteriormente, mas também na satisfação e lealdade - sendo cada vez mais importante para as novas gerações.

As próximas seções apresentam a conclusão geral obtida com a pesquisa, com o apontamento de implicações, além de limitações deste projeto e propostas de estudos futuros.

\subsection{Conclusões}

Desde o início da década de 2000, a educação superior tem apresentado altas taxas de crescimento como resultado, principalmente, de estímulos do mercado de trabalho e em função da facilidade de acesso, tanto físico, com maior abertura de unidades, quanto financeiro, consequência de políticas de crédito estudantil. 
Com a massificação do acesso à Internet e reconhecimento do formato da educação a distância pelo Ministério da Educação, o crescimento observado na graduação EaD foi ainda mais intenso do que no tradicional. Com um curso que permite certa flexibilização ao promover o estudo independente da ida ao prédio da faculdade e com menor encargo financeiro, esta modalidade viu suas matrículas mais que decuplicarem entre 2005 e 2015.

A rápida evolução, a mitificação a respeito da qualidade do ensino que rompe com o tradicional e a aparente falta de amarras do aluno com o curso, trouxe à tona preocupações com a percepção da qualidade, nível de satisfação do aluno e, principalmente, as taxas de evasão.

Nesta pesquisa foi possível identificar que o aluno da modalidade $\mathrm{EaD}$ percebe ser tão responsável quanto a faculdade por sua formação e quão benéfico é manter envolvimento nas atividades sugeridas pela instituição; porém, acredita que a faculdade não reconhece sua individualidade nem é aberta às sugestões e ideias para melhoria dos processos - e cada vez mais, os indivíduos desejam "fazer parte" no sentido mais amplo da expressão; desejam trocar experiências e levar suas opiniões para construção conjunta do valor do que estão consumindo.

Quando crê ser peça chave na criação de valor do sistema educacional, em paridade com o papel da faculdade, o estudante eleva sua percepção sobre a qualidade do curso, além da satisfação e, como consequência, torna-se mais leal - resultando, no longo prazo, em menores taxas de evasão.

Essa cocriação de valor ocorre por meio de duas vertentes, a coprodução e o valor percebido durante o uso. A primeira solidifica-se por meio do compartilhamento de conhecimento, da interação entre aluno e faculdade e da transparência da faculdade ao transmitir seus valores e interesses com os alunos. O valor em uso reflete as experiências dos alunos no curso, seu relacionamento com a faculdade e colegas e a avaliação de personalização do aprendizado levando em conta as necessidades individuais de cada um.

No modelo estrutural, o pilar do uso foi o mais relevante na composição da cocriação de valor, tornando fundamental que as faculdades aprimorem esta dimensão, em especial os 
atributos que abrangem o relacionamento. Ao encontro deste resultado, as instituições pesquisadas apontaram iniciativas de criação de áreas responsáveis pelo monitoramento das experiências do aluno, em conformidade com a tendência de outros setores de Serviços.

A pesquisa mostrou que a imagem da faculdade exerce importante influência sobre o interesse na cocriação de valor, principalmente para alunos de cursos de exatas e biológicas. Outro achado importante refere-se aos efeitos da cocriação de valor sobre satisfação e lealdade, maior para alunos mais novos, pertencentes à chamada Geração Y. Estes estudantes fazem parte do primeiro grupo a crescer tendo a facilidade do uso da Internet nas comunicações e, pode-se supor que representem o comportamento das gerações seguintes.

Entre os censos da educação superior de 2013 e 2015, a participação de alunos em EaD com idade até 24 anos foi de 19,2\% para 20,4\% (aumento de 6,25\%). Apesar de ainda longe da participação desta idade na educação presencial, esta variação em tão pouco tempo sugere uma escolha do jovem pelo EaD ao invés do presencial - seja pelo custo ou familiaridade com o meio eletrônico -, refutando a imagem de que a opção pelo ensino a distância ocorre por pressão da obtenção do diploma após anos do fim do ensino médio. Com essa movimentação, estimular a cocriação de valor é ainda mais relevante.

\subsection{Limitações do Estudo}

A principal limitação deste estudo refere-se à generalização dos resultados. Apesar de a amostra ter contemplado todas as regiões do país, ela ficou restrita às faculdades privadas e àqueles alunos que se interessaram em responder à pesquisa online.

A disponibilização dos e-mails de alunos foi realizada por meio de parceria com faculdades privadas e empresa de pesquisa da área de educação, sendo solicitada igual distribuição de alunos segundo região, área de conhecimento e ciclo do aluno no curso. Apesar disto, o retorno de alunos da região Sul e dos primeiros semestres ocorreu em 
maior número, indicando maior interesse na pesquisa - ou menor desconfiança deste público com o meio eletrônico. É importante ressaltar que, no convite de participação da pesquisa, não foi identificada a fonte de obtenção dos e-mails nem havia referência à faculdade nem oferecido prêmio/brinde para que houvesse estímulo à resposta.

\subsection{Estudos Futuros}

A área de educação apresenta diversas possibilidades de pesquisa com objetivos variados, tanto para o ensino superior - segmento estudado - quanto para os demais níveis. Entender, por exemplo, os aspectos que levam os pais a matricularem os filhos na escola básica e o quanto as crianças identificam-se com estes aspectos pode ser de grande relevância para melhorar o aproveitamento dos estudantes.

Quando o foco é a cocriação de valor, comparar os resultados obtidos nesta pesquisa com a percepção dos alunos da modalidade presencial é bastante relevante. O censo da educação superior mostrou que os alunos dos cursos presenciais ainda são, em sua maioria, mais novos do que os do $\mathrm{EaD}$ e o presente estudo indicou que são estes os indivíduos que mais sentem a necessidade de participação do processo de criação de valor. Quando o curso é presencial, a expectativa dos alunos com relação a determinados pontos e relacionamento com a faculdade, colegas e professores deve ser distinta da desenvolvida por alunos do $\mathrm{EaD}$, sendo razoável supor que os pesos dados aos elementos que compõem a cocriação de valor e a implicação desta na percepção de qualidade, satisfação e lealdade também sejam distintos.

Saindo do âmbito educacional, uma vez que se entende que não há prestação de serviço sem que haja envolvimento do consumidor - pelo menos no momento do uso -, tendo a área de serviços a importância cada vez maior na economia das nações desenvolvidas e o acesso cada vez maior de populações a meios de comunicação, como celulares, tablets e Internet, que permitem trocas de experiências entre indivíduos de lugares distantes do globo, faz sentido entender a criação conjunta de valor para outros segmentos, como saúde. 
Por fim, conforme apontado nas limitações do estudo, desenvolver uma pesquisa equivalente a esta, mas com foco em faculdades públicas, pode ser interessante como forma de ampliar políticas de acesso à educação superior com contenção da evasão. 


\section{REFERÊNCIAS BIBLIOGRÁFICAS}

ABED. (2014). Censo EaD.br: relatório analítico da aprendizagem a distância no Brasil 2013. Curitiba: Ibpex.

Aksoy, L., Keiningham, T. L., \& Oliver, R. L. (2014). Loyalty: its many sources and variations. In: Handbook of Service Marketing Research (pp. 37-51). Cheltenham: Edward Elgar Publishing, Inc.

Alreck, P. L., \& Settle, R. B. (1995). The Survey Research Handbook (2 ed.). Boston: Irwin McGraw-Hill.

Ballantyne, D., \& Varey, R. J. (2006). Introducing a dialogical orientation to the servicedominant logic of marketing. In: R. F. Lusch, \& S. L. Vargo, The service-dominant logic of marketing: Dialog, debate and directions (pp. 224-235). Armonk: ME Sharpe.

Barker, B., Friesbie, A., \& Patrick, K. (1989). Broadening the definition of distance education in the light of the new telecommunications technologies. The American Journal of Distance Education, 3(1), 20-29.

Barroso, C. L., \& Mello, G. N. (1975). O acesso da mulher ao ensino superior brasileiro. Cadernos de Pesquisa, 15, 47-77.

Barton, A. H., \& Lazarsfeld, P. F. (1955). Some functions of qualitative analysis in social research. Bobbs Merrill.

Becker, J.-M., Klein, K., \& Wetzels, M. (2012). Hierarchical latent variable models in PLS-SEM: guidelines for using reflective-formative type models. Long Range Planning, 45, pp. 359-394.

Bennet, R. (2003). Determinants of undergaduate student drop out in a university business studies department. Journal of Further and Higher Education, 27(2), 123-139.

Blalock, H. M. (1979). Social Statistics. New York: McGraw-Hill.

Bowden, J. L.-H., \& D'Alessandro, S. (2011). Co-creating value in higher education: the role of interactive classroom response technologies. Asian Social Science, 7(11), pp. 35-49.

Brambilla, F. R. (2010). Abordagem etnometodológica acerca da co-craição de valor na graduação em administração do ensino superior privado. Tese de Doutorado, Universidade do Vale do Rio dos Sinos, Departamento de Administração, São Leopoldo. 
Brambilla, F. R., \& Damacena, C. (2012). Estudo etnometodológico da cocriação de valor no ensino superior privado de administração com base na lógica dominante do serviço em marketing. REMark - Revista Brasileira de Marketing, 11(3), pp. 123152.

Bussab, W. O., \& Morettin, P. A. (2013). Estatística Básica (8 ed.). São Paulo: Saraiva.

Byrne, B. M. (2010). Structural equation modeling with AMOS: basic concepts, applications, and programming (2a. ed.). New York: Routledge.

Chan, K. W., Yim, C. K., \& Lam, S. S. (2010). Is customer participation in value creation a double-edged sword? Evidence from professional financial services across cultures. Journal of Marketing, 74(3), 48-64.

Chen, S.-C. (2015). Customer value and customer loyalty: is competition a missing link? Journal of Retailing and Consumer Services, 22, pp. 107-116.

Clayson, D. E., \& Haley, D. A. (2005). Marketing models in education: students as customers, products or partners. Marketing Education Review, 15(1), 1-10.

Cochran, W. (1977). Sampling Techniques (3 ed.). New York: John Wiley \& Sons.

Cohen, J. (1988). Statistical power analysis for the behavioral sciences (2 ed.). New York: Psychology Press.

Correio Braziliense. (07 de Outubro de 2016). Corte de verba do Fies derrubou matrículas. Correio Braziliense. Acesso em 01 de Fevereiro de 2017, disponível em http://bit.ly/2jZ4eck

Couper, M. P. (2000). Web-based surveys: a review of issues and approaches. Public Opinion Quartely, 64(4), 464-494.

Creswell, J. W. (1994). Research design: qualitative \& quantitative approaches. Thousand Oaks: SAGE.

Cronin Jr., J. J., \& Taylor, S. A. (1992). Measuring service quality: a reexamination and extension. Journal of Marketing, 56(3), pp. 55-68.

Day, G. (1999). The market driven organization: understanding, attracting and keeping valuable customers. New York: The Free Press.

DeVellis, R. F. (2012). Scale Development: Theory and Applications. Thousand Oaks: SAGE. 
Diamantopoulos, A., \& Siguaw, J. A. (2006). Formative versus reflective indicators in organizational measure development: a comparison and empirical illustration. British Journal of Management, 17(4), pp. 263-282.

Dohmen, G. (1967). Das Fernstudium. Ein neues pädagigusches Forschungs-und Arbeitsfeld. Tübingen: DIFF.

Eagle, L., \& Brennan, R. (2007). Are students customers? TQM and marketing perspectives. Quality Assurance in Education, 15(1), 44-60.

Edvardsson, B., Tronvoll, B., \& Gruber, T. (2011). Expanding undestanding of service exchange and value co-creation: a social construction apporach. Journal of the Academy of Marketing Science, 39(2), 327-339.

Emery, C., Kramer, T., \& Tian, R. (2001). Customers vs products: adopting an effective approach to business students. Quality Assurance in Education, 9(2), 110-115.

Faria, A. C., \& Costa, M. d. (2005). Gestão de custos logísticos: custeio baseado em atividades $(A B C)$, balanced scorecard (BSC) e valor econômico agregado (EVA). São Paulo: Atlas.

Faul, F., Erdfelder, E., Lang, A.-G., \& Buchner, A. (2007). G*Power: A flexible statistical power analysis program for the social, behavioral, and biomedical sciences. Behavior Research Methods, 39(2), pp. 175-191.

Flick, U. (2009). An introduction to qualitative research (4 ed.). Thousand Oaks: SAGE.

Folha de São Paulo. (30 de Setembro de 2015). Matrículas no ensino superior privado caem 30\%, com crise econômica e Fies. Folha de São Paulo. Acesso em 01 de Fevereiro de 2017, disponível em http://folha.com/no1688562

Fornell, C., Johnson, M. D., Anderson, E. W., Cha, J., \& Bryant, B. E. (1996). The american customer satisfaction index: nature, purpose, and findings. Journal of Marketing, 60(4), pp. 7-18.

Fuegen, S. (2012). The impact of mobile technologies on distance education. TechTrends, 56(6), pp. 49-53.

Fullerton, G. (2003). When does commitment lead to loyalty? Journal of Service Research, 5(4), pp. 333-344.

Galvagno, M., \& Dalli, D. (2014). Theory of value co-creation: a systematic literature review. Managing Service Quality, 24(6), 643-683. 
Garrison, D., \& Shale, D. (1987). Mapping the boundaries of distance education: problems in defining the field. The American Journal of Distance Education, 1(1), 4-13.

Gianesi, I., \& Correa, H. (1996). Administração estratégica de serviços: operações para a satisfação do cliente. São Paulo: Atlas.

Gil, A. C. (2002). Como elaborar projetos de pesquisa. São Paulo: Atlas.

Grewal, D., Iyer, G. R., Krishnan, R., \& Sharma, A. (2003). The Internet and the pricevalue-loyalty chain. Journal of Business Research, 56(5), pp. 391-398.

Grönroos, C. (2008). Service logic revisited: who creates value? And who co-creates? European Business Review, 20(4), 298-314.

Grönroos, C. (2011). Value co-creation in service logic: A critical analysis. Marketing Theory, 11(3), 279-301.

Grönroos, C., \& Gummerus, J. (2014). The service revolution and its marketing implications: service logic vs service-dominant logic. Managing Service Quality, 24(3), 206-229.

Gruber, T., FuB, S., Voss, R., \& Gläser-Zikuda, M. (2010). Examining student satisfaction with higher education services. International Journal of Public Sector Management, 23(2), pp. 105-123.

Gummesson, E. (1998). Implementation requires a relationship marketing paradigm. Journal of the Academy of Marketing Science, 242-249.

Gummesson, E. (2007). Exit services marketing - enter service marketing. Journal of Customer Behavior, 6(2), 113-141.

Gupta, S., \& Lehman, D. R. (2005). Managing customers as investments. Philadelphia: Wharton School Publishing.

Haeckel, S. H. (1999). Adaptative enterprise: creating and leading sense-and-respond organizations. Boston: Harvard School of Business.

Hair, J. F., Black, W. C., Babin, B. J., Anderson, R. E., \& Tatham, R. L. (2006). Multivariate data analysis (6 ed.). Upper Saddle River: Prentice Hall.

Hair, J. F., Hult, G. T., Ringle, C. M., \& Sarstedt, M. (2017). A primer on partial least squares structural equation modeling (PLS-SEM) (2 ed.). Newcastle, Australia: Sage. 
Halbesleben, J. R., Becker, J. A., \& Buckley, M. R. (2003). Considering the labor contributions of students: an alternative to student-as-customer metaphor. Journal of Education for Business, 78(5), 255-257.

Holmberg, B. (1977). Distance Education: A Survey and Bibliography. London: Kogan Page.

Hunt, S. D. (2000). A general theory of competition: resources, competences, productivity and economic growth. Thousand Oaks: Sage Publications.

IBGE. (2013). Projeção da População. Acesso em 03 de Fevereiro de 2017, disponível em http://www.ibge.gov.br/home/estatistica/populacao/projecao_da_populacao/2013/d efault_tab.shtm

IBGE. (2016). Contas Nacionais Trimestrais. Acesso em 15 de Maio de 2015, disponível em http://www.ibge.gov.br/home/estatistica/indicadores/pib/pib-volval_201603_8.shtm

IBGE. (2017). Pesquisa Nacional por Amostra de Domicílios Contínua - Mensal. Acesso em 12 de Fevereiro de 2017, disponível em http://www.ibge.gov.br/home/ estatistica/indicadores/trabalhoerendimento/pnad_continua_mensal/default.shtm

INEP. (2016). Sinopses Estatísticas da Educação Superior - Graduação. Acesso em 14 de Novembro de 2016, disponível em http://portal.inep.gov.br/superior-censosuperiorsinopse

Jarvis, C. B., Mackenzie, S. B., \& Podsakoff, P. M. (2003). A cirtical review of construct indicators and measurement model misspecification on marketing and consumer research. Journal of Consumer Reasearch, 30, 199-218.

Jones, T. O., \& Sasser, W. E. (1995). Why satisfied customers defect. Harvard Business Review, 73(6), pp. 89-99.

Judd, R. C. (1964). The case for redefining services. Journal of Marketing, 28(1), 58-59.

Kanji, G. K., \& Tambi, M. A. (1999). Total quality management in UK higher education institutions. Total Quality Management, 10(1), 129-153.

Keegan, D. (1996). Foundation of distance education (3 ${ }^{\text {a }}$ Edição ed.). Oxon: Routledge.

Keller, K. L. (2003). Brand synthesis: the multidimensionality of brand knowledge. Journal of Consumer Research, 29, 595-600.

Kleinbaum, D. G., Kupper, L. L., Muller, K. E., \& Nizam, A. (1998). Applied regression analysis and other multivariable methods (3 ed.). Pacific Grove: Duxbury Press. 
Koike, B. (26 de Outubro de 2015). Carlyle e Vinci usarão Uniasselvi como plataforma de expansão no setor. Valor Econômico. Acesso em 03 de Fevereiro de 2017, disponível em http://bit.ly/210UfFt

Kotler, P., \& Keller, K. L. (2006). Administração de marketing (12 ed.). São Paulo: Pearson Prentice Hall.

Ledden, L., \& Anderson, J. E. (2015). Consumer value co-creation in higher education. Am2015 - The magic in marketing (pp. 1-10). Universidade de Limerick, Irlanda: Academy of Marketing.

Levine, F., Locke, C., Searls, D., \& Weinberger, D. (2001). The cluetrain manifesto: the end of business as usual. Cambridge: Basic Books.

Lovelock, C. (1991). Services marketing. Englewood Cliffs: Prentice-Hall.

Maglio, P. P., Vargo, S. L., Caswell, N., \& Spohrer, J. (2009). The service system is the basic abstraction of service science. Information Systems and e-Business Management, 7(4), 395-406.

Mantovani, D. M. (2012). Distance education on the stakeholders' perspectives: student's, instructor's and administrator's percceptions. Tese de Doutorado, Universidade de São Paulo, Faculdade de Economia, Administração e Contabilidade, São Paulo.

Marconi, M. A., \& Lakatos, E. M. (2008). Técnicas de Pesquisa (7 ed.). São Paulo: Atlas.

Maroto, M. L. (1995). Educação a distância: aspectos conceituais. CEAD(8).

Marshall, A. (2014). Principles of economics (8 ed.). Hampshire: Palgrave Macmillan.

Masano, A. C. (2006). Expectativas e percepções do mercado bancário de pessoas físicas de alta renda no município de São Paulo. Dissertação de Mestrado, Universidade de São Paulo, Faculdade de Economia, Administração e Contabilidade, São Paulo.

MEB. (2011). Acesso em 22 de Janeiro de 2015, disponível em www.meb.org.br

Ministério da Educação. (2015). Universidade Aberta do Brasil. Acesso em 22 de Janeiro de 2015, disponível em http://portal.mec.gov.br/index.php?option=com_ content $\&$ view $=$ article $\&$ id=12265: universidade-aberta-do-brasiluab\&catid=248:uab-universidade-aberta-do-brasil \&Itemid=510

Mokyr, J. (2002). The gifts of Athena: historical origins of the knowledge economy. Princeton: Princeton University Press. 
Moore, M. (1973). Toward a theory of independent learning and teaching. Journal of Higher Education, 44, 661-679.

Moran, J. (2002). A educação superior a distância no Brasil. In: M. S. Soares, A Educação Superior no Brasil (pp. 251-274). Brasília: CAPES - UNESCO.

Mulyono, H. (2014). Mediating effect of trust and commitment on student loyalty. Business and Entrepreneurial Review, 14(1), pp. 57-76.

Normann, R. (2001). Reframing business: when the map changes the landscape. Chichester: Wiley.

Normann, R., \& Ramírez, R. (2005). Da cadeia de valor à constelação de valor: a criação da estratégia interativa. In: M. V. Rodrigues e Rodriguez, Harvard business review: gestão estratégica (pp. 53-82). Rio de Janeiro: Elsevier.

Nunes, I. B. (1993). Noções de educação a distância. Revista educação à distância, 4(5), 725.

Oliveira, D. M. (2009). Educação a distância e formação de professores em nível superior no Brasil. 32 ${ }^{a}$ Reunião Anual da Associação de Pós Graduação e Pesquisa em Educação - Anped, Caxambu. Timbaúba: Espaço Livre.

Parasuraman, A., Zeithaml, V. A., \& Berry, L. L. (1988). SERVQUAL: a multiple-item scale for measuring consumer perception of service quality. Journal of Retailing, 64(1), pp. 12-40.

Payne, A. F., Storbacka, K., \& Frow, P. (2008). Managing the co-creation of value. Journal of the Academy of Marketing Science, 36(1), 83-96.

Payne, A., \& Frow, P. (2014). Developing superior value propositions: a strategic marketing imperative. Journal of Service Marketing, 25(2), 213-227.

Payne, A., Storbacka, K., Frow, P., \& Knox, S. (2009). Co-creating brands: diagnosing and designing the relationship experience. Journal of Business Research, 62, pp. 379389.

Peters, O. (1973). Die didaktische Struktur des Fernunterrichts. Weinheim: Beltz.

Plé, L., \& Cáceres, R. C. (2010). Not always co-creation: introducing interactional codestruction of value in service-dominant logic. Journal of Services Marketing, $24(6), 430-437$.

Porter, M. E. (1980). Competitive strategy: techniques for analyzing industries and competitors. New York: Free Press. 
Porter, M. E. (1985). Competitive advantage: creating and sustaining superior performance. New York: Free Press.

Prahalad, C. K., \& Ramaswamy, V. (2000). Co-opting customer competence. Harvard Business Review, 78(1), 79-87.

Prahalad, C. K., \& Ramaswamy, V. (2003). The new frontier of experience innovation. Sloan Management Review, 12-18.

Prahalad, C. K., \& Ramaswamy, V. (2004a). Co-creating unique value with customers. Strategy and Leadership, 32(3), 4-9.

Prahalad, C. K., \& Ramaswamy, V. (2004b). Co-creation experiences: the next practice in value creation. Journal of Interactive Marketing, 18(3), 5-14.

Preti, O. (1996). Educação a distância: uma prática educativa mediadora e mediatizada. In: O. Preti, Educação a distância: inícios e indícios de um percurso (pp. 15-56). Cuiabá: Editora da Universidade Federal de Mato Grosso.

Ranjan, K. R., \& Read, S. (2016). Value co-creation: concept and measurement. Journal of the Academy of Marketing Science, 44(3), 290-315.

Rathmell, J. M. (1966). What is meant by services? Journal of Marketing, 30(4), 32-36.

Ravald, A., \& Grönroos, C. (1996). The value concept and relationship marketing. European Journal of Marketing, 30(2), 19-30.

Ringle, C., Sarstedt, M., \& Straub, D. (2012). Editor's comments: A critical look at use of PLS-SEM in MIS Quarterly. MIS Quarterly, 36(1), pp. iii-xiv.

Rosemberg, F., \& Amado, T. (1992). Mulheres na escola. Cadernos de Pesquisa, 80, 6274.

Saarijärvi, H., Kannan, P. K., \& Kuusela, H. (2013). Value co-creation: theoretical approaches and practical implications. European Business Review, 25(1), 6-19.

Saboia, J., Viva, M. A., \& Vargas, P. L. (2013). O uso dos dispositivos móveis no processo de ensino e aprendizagem no meio virtual. Revista Cesuca Virtual: Conhecimento sem Fronteiras, 1(1), pp. 1-13.

Salomi, G. G., Miguel, P. A., \& Abackerli, A. J. (2005). SERVQUAL x SERVPERF: Comparação entre instrumentos para avaliação da qualidade de serviços internos. Gestão \& Produção, 12(2), pp. 279-293. 
Shaw, A. W. (1912). Some problems in market distribution. The Quarterly Journal of Economics, 26(4), 703-765.

Sheth, J., Sisodia, R. S., \& Sharma, A. (2000). The antecedents and consequences of customer-centric marketing. Journal of the Academy of Marketing Science, 28, 5566.

Silva, A. S. (2014). Um modelo de antecedentes para a cocriação de valores em serviços de geriatria na cidade de São Paulo: uma aplicação da modelagem de equações estruturais. Dissertação de Mestrado, Universidade Municipal de São Caetano do Sul, Programa de Pós-Graduação em Administração, São Caetano do Sul.

Singh, J. (2000). Performance productivity and quality of frontline employees in service organizations. Journal of Marketing, 64(2), 15-34.

Sirdeshmukh, D., Singh, J., \& Sabol, B. (2002). Consumer trust, value and loyalty in relational exchanges. Journal of Marketing, 66(1), 15-37.

Sirvanci, M. (1996). Are students the true customers of higher education? Quality Progress, 29(10), 99-102.

Smith, A. (1998). An inquiry into the nature and causes of the wealth of nations. (K. Sutherland, Ed.) Oxford: Oxford University Press.

Solomon, M. R., Surprenant, C., Czepiel, J. A., \& Gutman, E. G. (1985). A role theory perspective on dyadic interactions: the service encounter. Journal of Marketing, 49(1), 99-111.

Sparks, L., Moutinho, L., \& Grönroos, C. (2015). Consumer dominant value creation. European Journal of Marketing, 49, 532-560.

Spohrer, J., Maglio, P. P., Bailey, J., \& Gruhl, D. (2007). Steps toward a science of service systems. Computer, 40, 71-77.

Storbacka, K., \& Lehtinen, J. R. (2001). Customer relationship management: creating competitive advantage through win-win relationship strategies. Cingapura: McGraw-Hill.

Svensson, G., \& Wood, G. (2007). Are university students really customers? When illusion may lead to delusion for all! International Journal of Education Management, 21(1), 17-28.

Taylor, S. A., \& Hunter, G. (2003). An exploratory investigation into the antecedents of satisfaction, brand attitude and loyalty within the (B2B) eCRM industry. Journal of Consumer Satisfaction, Dissatisfaction and Complaining Behavior, 16, pp. 19-35. 
Taylor, S. A., \& Hunter, G. (2014). Value, satisfaction and loyalty: an evolving conceptualization. Journal of Consumer Satisfaction, Dissatisfaction \& Complaining Behavior, 27, pp. 19-23.

Tien, J. M., \& Berg, D. (2006). On services research and education. Journal of Systems Science and Systems Engineering, 15(3), 257-283.

Tull, D. S., \& Hawkins, D. I. (1984). Marketing Reasearch: Measurement and Method (3 ed.). New York: Macmillan Publishing Co., Inc.

Udo, G. J., Bagchi, K. K., \& Kirs, P. J. (2011). Using SERQUAL to assess the quality of elearning experience. Computers in Human Behavior, 27, pp. 1272-1283.

Vargo, S. L., \& Lusch, R. F. (2004). Evolving to a new dominant logic for marketing. Journal of Marketing, 68(1), 1-17.

Vargo, S. L., \& Lusch, R. F. (2006). Service-dominant logic: What it is, what it is not, what it might be. In: R. F. Lusch, \& S. L. Vargo, The service-dominant logic of marketing: Dialog, debate and directions (pp. 43-56). Armonk: ME Sharpe.

Vargo, S. L., \& Lusch, R. F. (2008). Service-dominant logic: continuing the evolution. Journal of the Academy of Marketing Science, 36(1), 1-10.

Vargo, S. L., \& Lusch, R. F. (2011). It's all B2B ... and beyond: toward a systems perspective of the market. Industrial Marketing Management, 40(1), 181-187.

Velázquez, B. M., Saura, I. G., \& Molina, M. E. (2011). Conceptualizing and measuring loyalty: Towards a conceptual model of tourist loyalty antecedents. Journal of Vacation Marketing, 17(1), pp. 65-81.

Villas Bôas, B., \& Patu, G. (03 de Março de 2016). PIB do Brasil cai 3,8\% em 2015, o pior resultado desde 1990. Folha de São Paulo. Acesso em 31 de Janeiro de 2017, disponível em Folha de São Paulo: http://folha.com/no1745810

Wetzels, M., Odekerken-Schröder, G., \& van Oppen, C. (2009). Using PLS path modeling ofr assessing hierarchical construct models: guidelines and empirical illustration. MIS Quarterly, 33(1), pp. 177-195.

Wikstrom, S. (1996). Value creation by company-consumer interaction. Journal of Marketing Management, 12, 359-374.

Wright, K. B. (2005). Researching internet-based populations: advantages and disadvantages of online survey research, online questionnaire authoring software packages and web survey services. Journal of Computer-Mediated Communication, $10(3)$. 
Zeithaml, V. (1988). Consumer perception of price, quality and value: a means-ends-model and synthesis of evidence. Journal of Marketing, 52, 2-22.

Zeithaml, V. A., Parasuraman, A., \& Berry, L. L. (1985). Problems and strategies in service marketing. Journal of Marketing, 49, 33-46.

Zuboff, S., \& Maxmin, J. (2002). The support economy. NewYork: Penguin. 


\section{APÊNDICES}

\section{Apêndice A - Roteiro de Pesquisa Qualitativa}

Para a entrevista qualitativa foi formulado roteiro de perguntas, para direcionamento da conversa, sem que houvesse, porém, a necessidade de manutenção estrita das perguntas relacionadas; o roteiro pode ser visto como uma pauta de reunião, com os principais pontos a serem levantados durante a entrevista.

A pesquisa qualitativa tinha como principais objetivos:

- Levantamento de atributos para a definição de cocriação de valor com contexto $\mathrm{EaD}$;

- Avaliação dos demais construtos da pesquisa na visão dos entrevistados, de forma que houvesse validação ou necessidade de inclusão de novos itens;

- Entendimento da dinâmica dos cursos e dos alunos EaD da faculdade representada pelo entrevistado.

O início da pesquisa ocorreu com a pesquisadora apresentando os conceitos teóricos de cocriação de valor, inserindo os entrevistados no contexto geral do modelo estudado. Não foram detalhados os elementos que compunham cada um dos construtos, porém, foram ditos os nomes das dimensões a serem pesquisadas - Qualidade Percebida, Satisfação e Lealdade, além da própria Cocriação de Valor - e suas relações esperadas.

Foram, então, os itens abordados, separados por dois assuntos:

\section{Modelo}

- Após análise do modelo geral, sente falta de algo? Faz sentido esperar estas relações? 
- Quais os pontos mais relevantes para um aluno de EaD na decisão de fazer um curso deste tipo?

- Como ocorre a valoração do curso e da faculdade por um aluno de EaD?

- O aluno sente-se importante no curso e/ou para a faculdade?

- O aluno gosta de se relacionar com a faculdade, dando sugestões ou participando de eventos organizados por ela?

- Como ocorre a percepção de qualidade para um aluno de $\mathrm{EaD}$ ?

- Como ocorre a percepção de satisfação para um aluno de EaD?

- Qual a definição de lealdade para um aluno de EaD?

- Há alguma dimensão que deveria estar contemplada para a obtenção da lealdade?

- Como ocorre a taxa de evasão? Qual o motivo alegado para desistência?

- Há diferenciação das expectativas dos alunos segundo idade ou tipo de curso ou região?

- Qual a principal razão para o aluno escolher a faculdade A e não a B?

- Há algum tipo de preconceito pelo curso EaD?

\section{Faculdade e Alunos}

- Quantos alunos a faculdade possui na modalidade EaD?

- Como ocorre a distribuição dos alunos segundo tipologia de curso e regiões?

- Como é o aluno de um curso de EaD? Perfil

- Qual a relação do aluno com o professor? Periodicidade, facilidade de acesso

- Existe a imagem de um monitor ou tutor para cada turma?

- Qual a relação do aluno com os colegas? A faculdade disponibiliza espaços para interação?

- Como é a infraestrutura da faculdade para suportar os alunos de EaD com relação aos aspectos burocráticos ou de tecnologia (computacionais)?

- Há entrega de listas de exercícios? Tarefa de casa?

- Como é a dinâmica dos alunos no dia a dia? Todos os cursos apresentam a mesma carga presencial? Há sempre um período presencial?

- Fazem pesquisas periódicas com alunos? Como é a receptividade/aderência? 


\section{Apêndice B - Instrumento de Coleta de Dados}

Olá

Você está convidado(a) a participar da pesquisa de uma tese de doutorado da Faculdade de Economia e Administração da Universidade de São Paulo para entender o ensino a distância na visão do aluno. Mesmo que não esteja fazendo nenhum curso a distância atualmente, você pode participar.

O tempo total desta pesquisa será de 15 minutos.

As respostas são confidenciais e sempre serão avaliadas de forma agregada, sem a possibilidade de identificação do(a) respondente em nenhum momento.

Caso tenha alguma dúvida ou questionamento sobre a pesquisa, fique à vontade para entrar em contato com Profa. Danielle Daffre pelo email danidafc@usp.br.

Obrigada pelo seu tempo e contribuição. Suas respostas são muito importantes.

Q1. Atualmente você é aluno(a) de um curso de graduação a distância?

1. Sim (IR PARA Q5)

2. Não, mas já fui aluno(a) de graduação a distância

3. Não, nunca fui aluno(a) de graduação a distância (SAIR DA PESQUISA)

Q2. Qual das frases abaixo reflete a sua situação sobre o curso de graduação a distância? (Considere a graduação a distância mais recente em que se matriculou)

1. Já me formei através de uma graduação a distância (IR PARA Q3)

2. Tranquei a matrícula de uma graduação a distância (IR PARA Q4)

3. Cancelei a matrícula de uma graduação a distância (IR PARA Q4)

4. Outro motivo (SAIR DA PESQUISA) 
Q3. Há quanto tempo você se formou em um curso de graduação a distância?

1. Menos de 1 ano (IR PARA A Q6)

2. Entre 1 e 5 anos (IR PARA A Q6)

3. Mais de 5 anos (IR PARA A Q6)

Q4. Há quanto tempo você trancou ou cancelou a matrícula um curso de graduação a distância?

1. Menos de 1 mês (IR PARA A Q6)

2. Entre 1 e 3 meses (IR PARA A Q6)

3. Entre 4 e 6 meses (IR PARA A Q6)

4. Entre 7 meses e 1 ano (IR PARA A Q6)

5. Mais de 1 ano (IR PARA A Q6)

Q5. Em qual período você está? (Caso esteja cursando matérias de mais de um período, considere aquele de maior número de matérias)

1. $1^{\mathrm{o}}$ semestre

2. $2^{\mathrm{o}}$ semestre

3. $2^{\circ}$ ano

4. $3^{\circ}$ ano

5. $4^{\circ}$ ano

6. $5^{\circ}$ ano

7. Outro

Todas as perguntas a seguir devem ser respondidas pensando em seu curso de graduação a distância atual (caso esteja cursando) ou aquele que cursou há menos tempo.

Se você faz ou fez mais de uma graduação a distância, considere aquela que cursa atualmente ou a que cursou há menos tempo. 
Q6. Qual a faculdade do seu curso de graduação a distância?

1. Anhanguera

2. Anhembi Morumbi

3. Estácio

4. Unip

5. Unopar

6. Outra

Q7. Qual a localização de seu polo presencial?

(SELEÇÃO DE UF)

(SELEÇÃO DA CAPITAL DA UF APONTADA ou “OUTRA CIDADE”)

Q8. Qual a tipologia do seu curso de graduação a distância?

1. Bacharelado

2. Licenciatura

3. Tecnólogo

4. Outra (SAIR DA PESQUISA)

Q9. Qual a área de seu curso de graduação a distância?

1. Biológicas/Saúde (IR PARA Q9a)

2. Exatas (IR PARA Q9b)

3. Humanas (IR PARA Q9c)

Q9a. Qual o seu curso de graduação a distância?

1. Biologia/Ciências Biológicas

2. Ciências Agrárias

3. Ciências Naturais

4. Educação Física

5. Enfermagem

6. Outro 
Q9b. Qual o seu curso de graduação a distância?

1. Análise de Sistemas

2. Ciência da Computação

3. Engenharia

4. Física

5. Matemática

6. Química

7. Outro

Q9c. Qual o seu curso de graduação a distância?

1. Administração

2. Ciências Contábeis/Contabilidade

3. Direito

4. Letras

5. Pedagogia

6. Outro

Dê uma nota de 1 a 10 para cada uma das afirmações a seguir, conforme seu grau de concordância. Considere como referência:

- Baixa concordância: 1 a 4

- Média concordância: 5 e 6

- Alta concordância: 7 a 10

Você pode escolher qualquer número de 1 a 10, de acordo com sua opinião sobre o curso. (ALEATORIZAÇÃO DE PERGUNTAS)

\begin{tabular}{|l|l|l|l|l|l|l|l|l|l|l|l|}
\hline & \multicolumn{1}{|l|}{} & 1 & 2 & 3 & 4 & 5 & 6 & 7 & 8 & 9 & 10 \\
\hline 1 & $\begin{array}{l}\text { A faculdade é aberta às ideias e sugestões dos alunos } \\
\text { para melhoria dos cursos existentes }\end{array}$ & & & & & & & & & \\
\hline 2 & $\begin{array}{l}\text { A faculdade é aberta às ideias e sugestões dos alunos } \\
\text { para criação de novos cursos/turmas }\end{array}$ & & & & & & & & & \\
\hline 3 & $\begin{array}{l}\text { A faculdade fornece informações suficientes para o } \\
\text { bom andamento do curso }\end{array}$ & & & & & & & & & & \\
\hline 4 & $\begin{array}{l}\text { Eu gastaria tempo esforço para compartilhar com a } \\
\text { faculdade minhas ideias e sugestões }\end{array}$ & & & & & & & & & & \\
\hline 5 & $\begin{array}{l}\text { A faculdade fornece ambiente favorável para que eu } \\
\text { possa expressar minhas opiniões e sugestões }\end{array}$ & & & & & & & & \\
\hline
\end{tabular}




\begin{tabular}{|c|c|c|c|c|c|c|c|c|c|c|c|}
\hline & & 1 & 2 & 3 & 4 & 5 & 6 & 7 & 8 & 9 & 10 \\
\hline 6 & $\begin{array}{l}\text { As experiências vividas no curso ficarão em minha } \\
\text { lembrança por um longo tempo }\end{array}$ & & & & & & & & & & \\
\hline 7 & $\begin{array}{l}\text { As experiências e seus resultados são diferentes } \\
\text { dependendo do aluno }\end{array}$ & & & & & & & & & & \\
\hline 8 & $\begin{array}{l}\text { Os alunos têm a oportunidade da experimentação e da } \\
\text { prática para ampliar seu conhecimento }\end{array}$ & & & & & & & & & & \\
\hline 9 & $\begin{array}{l}\text { Durante o curso é permitido que os alunos expressem } \\
\text { suas necessidades individuais }\end{array}$ & & & & & & & & & & \\
\hline 10 & $\begin{array}{l}\text { A faculdade transmite aos alunos informações } \\
\text { relevantes acerca do processo de ensino a distância }\end{array}$ & & & & & & & & & & \\
\hline 11 & $\begin{array}{l}\text { A faculdade permite a completa interação dos alunos } \\
\text { com a instituição }\end{array}$ & & & & & & & & & & \\
\hline 12 & $\begin{array}{l}\text { Espera-se que os alunos sejam proativos na interação } \\
\text { com a faculdade }\end{array}$ & & & & & & & & & & \\
\hline 13 & $\begin{array}{l}\text { Os benefícios do curso dependem do estudante e de } \\
\text { seu envolvimento nas atividades sugeridas pela } \\
\text { faculdade }\end{array}$ & & & & & & & & & & \\
\hline 14 & $\begin{array}{l}\text { A faculdade atende às necessidades individuais de } \\
\text { cada aluno }\end{array}$ & & & & & & & & & & \\
\hline 15 & $\begin{array}{l}\text { As necessidades individuais dos alunos são decisivas } \\
\text { no grau de envolvimento com a faculdade }\end{array}$ & & & & & & & & & & \\
\hline 16 & $\begin{array}{l}\text { A faculdade fornece boas experiências, além do } \\
\text { benefício de se obter o diploma }\end{array}$ & & & & & & & & & & \\
\hline 18 & $\begin{array}{l}\text { Mantenho relacionamento com colegas além das aulas } \\
\text { presenciais }\end{array}$ & & & & & & & & & & \\
\hline 19 & $\begin{array}{l}\text { A faculdade prepara para desafios do mercado de } \\
\text { trabalho }\end{array}$ & & & & & & & & & & \\
\hline & $\begin{array}{l}\text { A faculdade dispõe de infraestrutura física que } \\
\text { permite ao aluno desfrutar completamente da vida } \\
\text { universitária }\end{array}$ & & & & & & & & & & \\
\hline 21 & Tenho um relacionamento próximo com a faculdade & & & & & & & & & & \\
\hline 22 & $\begin{array}{l}\text { A faculdade possui bom desempenho em avaliações } \\
\text { do governo (ENADE, CAPES) }\end{array}$ & & & & & & & & & & \\
\hline 23 & $\begin{array}{l}\text { Os alunos escrevem positivamente sobre a faculdade } \\
\text { em redes sociais/mídia }\end{array}$ & & & & & & & & & & \\
\hline 24 & Minha família e amigos consideram a faculdade boa & & & & & & & & & & \\
\hline 25 & $\begin{array}{l}\text { A faculdade dispõe de atendimento para apoio aos } \\
\text { problemas técnicos ou administrativos dos alunos }\end{array}$ & & & & & & & & & & \\
\hline 26 & A faculdade busca saber minhas preferências & & & & & & & & & & \\
\hline 27 & $\begin{array}{l}\text { A missão e os valores da faculdade estão em linha } \\
\text { com os meus valores }\end{array}$ & & & & & & & & & & \\
\hline & $\begin{array}{l}\text { A faculdade considera que os alunos exercem um } \\
\text { papel tão importante quanto o dela para andamento do } \\
\text { curso }\end{array}$ & & & & & & & & & & \\
\hline 29 & $\begin{array}{l}\text { O papel do aluno e o da faculdade são igualmente } \\
\text { importantes para a formação do aluno }\end{array}$ & & & & & & & & & & \\
\hline 30 & $\begin{array}{l}\text { O nome da faculdade abre portas no mercado de } \\
\text { trabalho independente do desempenho do aluno no } \\
\text { curso }\end{array}$ & & & & & & & & & & \\
\hline 31 & Considero as aulas muito boas & & & & & & & & & & \\
\hline 32 & Os instrutores inspiram segurança & & & & & & & & & & \\
\hline
\end{tabular}




\begin{tabular}{|c|c|c|c|c|c|c|c|c|c|c|c|}
\hline \multirow{3}{*}{\multicolumn{2}{|c|}{\begin{tabular}{|l|l}
33 & Os instrutores dão retorno sobre as tarefas solicitadas \\
34 & Os instrutores preocupam-se com os alunos
\end{tabular}}} & 1 & 2 & 3 & 4 & 5 & 6 & 7 & 8 & 9 & 10 \\
\hline & & & & & & & & & & & \\
\hline & & & & & & & & & & & \\
\hline & $\begin{array}{l}\text { Os instrutores compreendem as necessidades } \\
\text { individuais dos alunos }\end{array}$ & & & & & & & & & & \\
\hline 36 & $\begin{array}{l}\text { Os instrutores pensam nos interesses de longo prazo } \\
\text { dos alunos }\end{array}$ & & & & & & & & & & \\
\hline & $\begin{array}{l}\text { Os instrutores motivam e estimulam os alunos a } \\
\text { darem o seu melhor no curso }\end{array}$ & & & & & & & & & & \\
\hline 38 & $\begin{array}{l}\text { Os instrutores (professores e tutores) conhecem } \\
\text { profundamente a sua área }\end{array}$ & & & & & & & & & & \\
\hline 39 & $\begin{array}{l}\text { Os instrutores são justos e imparciais ao atribuir notas } \\
\text { aos trabalhos e provas }\end{array}$ & & & & & & & & & & \\
\hline 40 & $\begin{array}{l}\text { Os instrutores respondem as dúvidas a eles enviadas } \\
\text { de forma completa e cuidadosa }\end{array}$ & & & & & & & & & & \\
\hline 41 & $\begin{array}{l}\text { Os instrutores conhecem profundamente os materiais } \\
\text { do curso }\end{array}$ & & & & & & & & & & \\
\hline 42 & A faculdade é confiável & & & & & & & & & & \\
\hline 43 & A faculdade é inovadora & & & & & & & & & & \\
\hline 44 & $\begin{array}{l}\text { A faculdade serve de exemplo em educação a } \\
\text { distância no Brasil }\end{array}$ & & & & & & & & & & \\
\hline 45 & A faculdade é sinônimo de qualidade de ensino & & & & & & & & & & \\
\hline 46 & A faculdade apresenta boa reputação & & & & & & & & & & \\
\hline & $\begin{array}{l}\text { Os instrutores são acessíveis fora dos momentos de } \\
\text { encontro }\end{array}$ & & & & & & & & & & \\
\hline & $\begin{array}{l}\text { Os instrutores dão retorno às solicitações dos alunos } \\
\text { rapidamente }\end{array}$ & & & & & & & & & & \\
\hline $49:$ & $\begin{array}{l}\text { Os instrutores fazem tudo o que podem para ajudar os } \\
\text { alunos, mesmo que isso vá além de suas } \\
\text { responsabilidades }\end{array}$ & & & & & & & & & & \\
\hline & $\begin{array}{l}\text { Os instrutores valorizam perguntas e comentários dos } \\
\text { alunos }\end{array}$ & & & & & & & & & & \\
\hline & $\begin{array}{l}\text { Os recursos de áudio utilizados nos cursos são } \\
\text { apropriados }\end{array}$ & & & & & & & & & & \\
\hline & $\begin{array}{l}\text { Os recursos de vídeo utilizados nos cursos são } \\
\text { apropriados }\end{array}$ & & & & & & & & & & \\
\hline 53 & $\begin{array}{l}\text { O curso utiliza adequadamente ferramentas } \\
\text { multimídia (áudio, vídeo, animações, gráficos) }\end{array}$ & & & & & & & & & & \\
\hline 54 & O ambiente virtual apresenta informações confiáveis & & & & & & & & & & \\
\hline 55 & O conteúdo disponibilizado é de alta qualidade & & & & & & & & & & \\
\hline 56 & $\begin{array}{l}\text { O conteúdo apresentado no ambiente virtual é } \\
\text { relevante para mim }\end{array}$ & & & & & & & & & & \\
\hline 57 & $\begin{array}{l}\text { Há flexibilidade de horário para realização das } \\
\text { atividades }\end{array}$ & & & & & & & & & & \\
\hline 58 & $\begin{array}{l}\text { O ambiente virtual de aprendizagem é interativo e } \\
\text { dinâmico }\end{array}$ & & & & & & & & & & \\
\hline 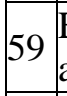 & $\begin{array}{l}\text { Eu recomendaria este curso a distancia aos meus } \\
\text { amigos e familiares }\end{array}$ & & & & & & & & & & \\
\hline 60 & $\begin{array}{l}\text { Eu certamente faria outro curso de graduação ou uma } \\
\text { pós-graduação a distância }\end{array}$ & & & & & & & & & & \\
\hline $61 \mathrm{II}$ & Pretendo chegar ao final do curso & & & & & & & & & & \\
\hline
\end{tabular}




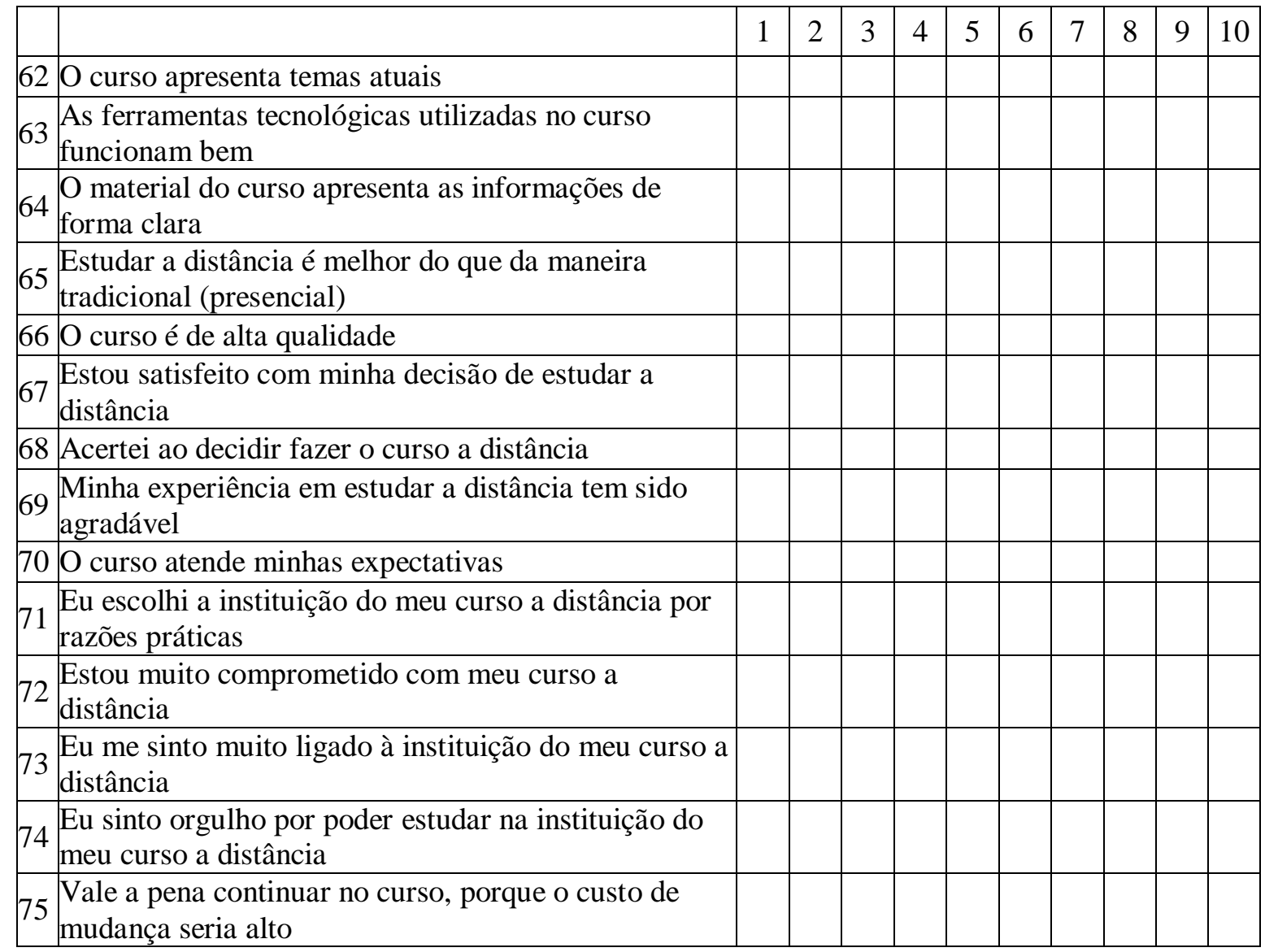

Q10. Pensando em todos os atributos que você avaliou até agora, dê uma nota geral de 1 a 10 para o seu curso a distância.

\begin{tabular}{|l|l|l|l|l|l|l|l|l|l|}
\hline 1 & 2 & 3 & 4 & 5 & 6 & 7 & 8 & 9 & 10 \\
\hline & & & & & & & & & \\
\hline
\end{tabular}

Está quase acabando! Gostaríamos de saber um pouco mais sobre você.

\section{Q11. Idade}

1. Até 16 anos

2. 17 a 24 anos

3. 25 a 29 anos

4. 30 a 34 anos

5. 35 a 39 anos

6. 40 a 49 anos

7. 50 anos ou mais 
Q12. Gênero

1. Feminino

2. Masculino

Q13. Estado Civil

1. Solteiro

2. Casado/União estável

3. Separado/Divorciado

4. Viúvo

5. Outro

Q14. Possui filhos(as)?

1. Sim (IR PARA Q15)

2. Não

Q15. Qual a idade do(a) seu(sua) filho(a) mais novo(a)?

1. Até 2 anos

2. Entre 2 e 5 anos

3. Entre 6 e 15 anos

4. Entre 16 e 18 anos

5. 19 anos ou mais

Q16. Atualmente, seu trabalho é

1. Remunerado

2. Voluntário

3. No lar

4. Não trabalho, mas estou procurando emprego

5. Não trabalho e não estou procurando emprego

6. Outro

Obrigada por responder a essa pesquisa! 
Apêndice C - Tabelas de Validade Discriminante, Convergente e Medidas de Confiabilidade para Modelo Final

Tabela 29

Avaliação do critério de Fornell-Larcker para o modelo final

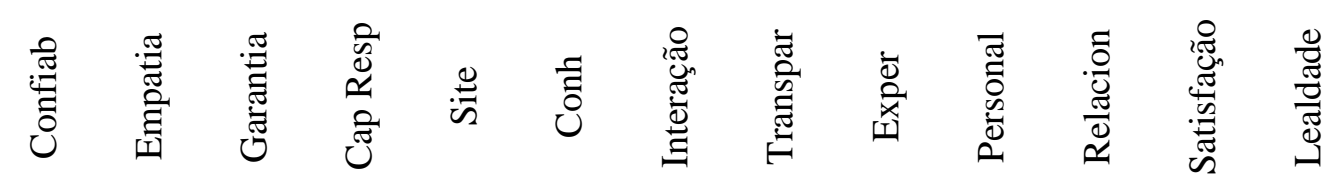

\begin{tabular}{l|l|llllllllllll}
\hline Confiab & $\mathbf{0 , 9 2}$ & 0,86 & 0,88 & 0,84 & 0,77 & 0,73 & 0,73 & 0,73 & 0,74 & 0,74 & 0,78 & 0,72 & 0,71 \\
Empatia & 0,86 & $\mathbf{0 , 9 5}$ & 0,84 & 0,87 & 0,68 & 0,67 & 0,69 & 0,70 & 0,70 & 0,69 & 0,72 & 0,65 & 0,65 \\
Garantia & 0,88 & 0,84 & $\mathbf{0 , 8 9}$ & 0,84 & 0,72 & 0,68 & 0,68 & 0,67 & 0,69 & 0,69 & 0,71 & 0,69 & 0,67 \\
Cap Resp & 0,84 & 0,87 & 0,84 & $\mathbf{0 , 9 3}$ & 0,70 & 0,68 & 0,70 & 0,68 & 0,70 & 0,69 & 0,71 & 0,64 & 0,65 \\
Site & 0,77 & 0,68 & 0,72 & 0,70 & $\mathbf{0 , 9 1}$ & 0,72 & 0,77 & 0,76 & 0,76 & 0,78 & 0,80 & 0,77 & 0,78 \\
Conh & 0,73 & 0,67 & 0,68 & 0,68 & 0,72 & $\mathbf{0 , 8 8}$ & 0,85 & 0,86 & 0,81 & 0,80 & 0,83 & 0,66 & 0,65 \\
Interação & 0,73 & 0,69 & 0,68 & 0,70 & 0,77 & 0,85 & $\mathbf{0 , 9 1}$ & 0,86 & 0,82 & 0,82 & 0,83 & 0,68 & 0,69 \\
Transpar & 0,73 & 0,70 & 0,67 & 0,68 & 0,76 & 0,86 & 0,86 & $\mathbf{0 , 8 8}$ & 0,83 & 0,84 & 0,87 & 0,69 & 0,70 \\
Exper & 0,74 & 0,70 & 0,69 & 0,70 & 0,76 & 0,81 & 0,82 & 0,83 & $\mathbf{0 , 8 9}$ & 0,81 & 0,88 & 0,71 & 0,71 \\
Personal & 0,74 & 0,69 & 0,69 & 0,69 & 0,78 & 0,80 & 0,82 & 0,84 & 0,81 & $\mathbf{0 , 8 5}$ & 0,83 & 0,70 & 0,68 \\
Relacion & 0,78 & 0,72 & 0,71 & 0,71 & 0,80 & 0,83 & 0,83 & 0,87 & 0,88 & 0,83 & $\mathbf{0 , 9 0}$ & 0,73 & 0,73 \\
Satisfaçãon & 0,72 & 0,65 & 0,69 & 0,64 & 0,77 & 0,66 & 0,68 & 0,69 & 0,71 & 0,70 & 0,73 & $\mathbf{0 , 9 3}$ & 0,89 \\
Lealdade & 0,71 & 0,65 & 0,67 & 0,65 & 0,78 & 0,65 & 0,69 & 0,70 & 0,71 & 0,68 & 0,73 & 0,89 & $\mathbf{0 , 9 3}$ \\
\hline
\end{tabular}

Nota. Elaborado pela autora. Na diagonal (destacada com borda) encontra-se a raiz quadrada do AVE e nos demais campos, as correlações entre construtos. Números em negrito representam o maior valor observado para cada construto. $\mathrm{N}=400$ 
Tabela 30

Cargas fatoriais do modelo final

\begin{tabular}{|c|c|c|c|c|c|c|c|c|c|c|c|c|c|}
\hline & 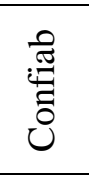 & 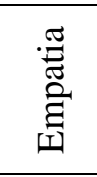 & 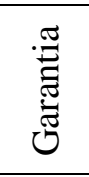 & 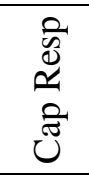 & $\stackrel{\mathscr{V}}{5}$ & हี & 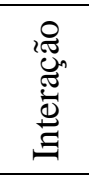 & 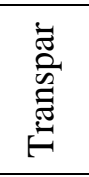 & 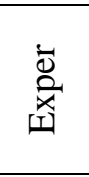 & 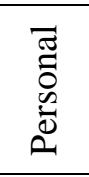 & 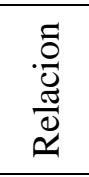 & 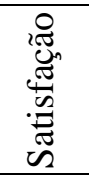 & 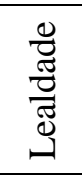 \\
\hline Confiab1 & 0,92 & 0,75 & 0,78 & 0,74 & 0,79 & 0,70 & 0,71 & 0,72 & 0,73 & 0,71 & 0,77 & 0,73 & 0,71 \\
\hline Confiab2 & 0,94 & 0,81 & 0,84 & 0,75 & 0,68 & 0,66 & 0,64 & 0,64 & 0,68 & 0,65 & 0,70 & 0,64 & 0,62 \\
\hline Confiab3 & $\mathbf{0 , 8 9}$ & 0,81 & 0,81 & 0,82 & 0,62 & 0,65 & 0,66 & 0,65 & 0,63 & 0,65 & 0,66 & 0,59 & 0,60 \\
\hline Empat1 & 0,83 & 0,94 & 0,78 & 0,82 & 0,63 & 0,65 & 0,66 & 0,67 & 0,66 & 0,67 & 0,69 & 0,60 & 0,58 \\
\hline Empat4 & 0,80 & 0,95 & 0,82 & 0,82 & 0,67 & 0,63 & 0,66 & 0,65 & 0,67 & 0,63 & 0,68 & 0,64 & 0,64 \\
\hline Garant1 & 0,79 & 0,74 & $\mathbf{0 , 9 0}$ & 0,73 & 0,64 & 0,58 & 0,56 & 0,56 & 0,62 & 0,61 & 0,63 & 0,61 & 0,61 \\
\hline Garant2 & 0,73 & 0,74 & 0,86 & 0,70 & 0,62 & 0,57 & 0,59 & 0,60 & 0,57 & 0,60 & 0,60 & 0,61 & 0,60 \\
\hline Garant3 & 0,81 & 0,78 & 0,88 & 0,83 & 0,63 & 0,64 & 0,68 & 0,63 & 0,62 & 0,64 & 0,65 & 0,62 & 0,58 \\
\hline Garant4 & 0,80 & 0,72 & 0,92 & 0,73 & 0,65 & 0,61 & 0,59 & 0,59 & 0,63 & 0,61 & 0,65 & 0,60 & 0,59 \\
\hline Resp1 & 0,78 & 0,79 & 0,75 & 0,93 & 0,66 & 0,63 & 0,65 & 0,64 & 0,67 & 0,64 & 0,68 & 0,61 & 0,61 \\
\hline Resp2 & 0,76 & 0,79 & 0,77 & 0,93 & 0,63 & 0,62 & 0,63 & 0,62 & 0,62 & 0,64 & 0,65 & 0,61 & 0,61 \\
\hline Resp4 & 0,78 & 0,82 & 0,81 & 0,92 & 0,66 & 0,63 & 0,66 & 0,64 & 0,64 & 0,63 & 0,65 & 0,57 & 0,58 \\
\hline Site2 & 0,67 & 0,59 & 0,62 & 0,61 & 0,90 & 0,61 & 0,66 & 0,65 & 0,63 & 0,66 & 0,67 & 0,64 & 0,67 \\
\hline Site4 & 0,67 & 0,62 & 0,67 & 0,62 & $\mathbf{0 , 9 1}$ & 0,62 & 0,68 & 0,67 & 0,66 & 0,70 & 0,70 & 0,68 & 0,69 \\
\hline Site5 & 0,75 & 0,66 & 0,70 & 0,68 & 0,93 & 0,68 & 0,70 & 0,71 & 0,73 & 0,74 & 0,78 & 0,73 & 0,74 \\
\hline Site8 & 0,67 & 0,61 & 0,60 & 0,63 & 0,90 & 0,68 & 0,73 & 0,71 & 0,72 & 0,72 & 0,73 & 0,73 & 0,73 \\
\hline Conh1 & 0,63 & 0,58 & 0,58 & 0,58 & 0,62 & 0,91 & 0,75 & 0,77 & 0,71 & 0,71 & 0,72 & 0,55 & 0,54 \\
\hline Conh2 & 0,58 & 0,59 & 0,53 & 0,57 & 0,53 & 0,87 & 0,67 & 0,71 & 0,65 & 0,64 & 0,68 & 0,51 & 0,51 \\
\hline Conh3 & 0,71 & 0,62 & 0,66 & 0,64 & 0,72 & $\mathbf{0 , 8 7}$ & 0,81 & 0,78 & 0,78 & 0,76 & 0,80 & 0,66 & 0,67 \\
\hline Inter1 & 0,63 & 0,64 & 0,60 & 0,62 & 0,68 & 0,76 & 0,90 & 0,77 & 0,74 & 0,73 & 0,74 & 0,62 & 0,61 \\
\hline Inter2 & 0,69 & 0,62 & 0,66 & 0,64 & 0,73 & 0,75 & 0,92 & 0,76 & 0,74 & 0,76 & 0,74 & 0,65 & 0,65 \\
\hline Inter3 & 0,67 & 0,64 & 0,60 & 0,65 & 0,69 & 0,81 & 0,92 & 0,82 & 0,76 & 0,76 & 0,78 & 0,59 & 0,60 \\
\hline Transp1 & 0,66 & 0,64 & 0,58 & 0,61 & 0,63 & 0,78 & 0,76 & 0,87 & 0,73 & 0,73 & 0,78 & 0,59 & 0,59 \\
\hline Transp2 & 0,65 & 0,58 & 0,60 & 0,54 & 0,68 & 0,72 & 0,73 & 0,88 & 0,71 & 0,74 & 0,76 & 0,63 & 0,65 \\
\hline Transp3 & 0,63 & 0,63 & 0,60 & 0,66 & 0,69 & 0,77 & 0,79 & 0,90 & 0,75 & 0,76 & 0,77 & 0,60 & 0,63 \\
\hline Exp1 & 0,65 & 0,61 & 0,61 & 0,59 & 0,66 & 0,69 & 0,71 & 0,70 & $\mathbf{0 , 8 8}$ & 0,67 & 0,75 & 0,65 & 0,64 \\
\hline Exp3 & 0,65 & 0,63 & 0,58 & 0,61 & 0,64 & 0,71 & 0,72 & 0,73 & $\mathbf{0 , 8 7}$ & 0,71 & 0,77 & 0,60 & 0,59 \\
\hline Exp4 & 0,69 & 0,63 & 0,65 & 0,67 & 0,73 & 0,76 & 0,77 & 0,78 & 0,92 & 0,80 & 0,84 & 0,65 & 0,67 \\
\hline Person1 & 0,53 & 0,48 & 0,55 & 0,49 & 0,60 & 0,58 & 0,58 & 0,58 & 0,60 & 0,79 & 0,59 & 0,53 & 0,51 \\
\hline Person2 & 0,71 & 0,64 & 0,64 & 0,65 & 0,75 & 0,77 & 0,81 & 0,81 & 0,80 & $\mathbf{0 , 8 9}$ & 0,83 & 0,69 & 0,67 \\
\hline Person3 & 0,62 & 0,62 & 0,57 & 0,61 & 0,61 & 0,68 & 0,69 & 0,73 & 0,67 & 0,87 & 0,69 & 0,55 & 0,54 \\
\hline Relac2 & 0,70 & 0,67 & 0,65 & 0,66 & 0,70 & 0,76 & 0,76 & 0,77 & 0,83 & 0,76 & $\mathbf{0 , 8 9}$ & 0,64 & 0,63 \\
\hline Relac4 & 0,68 & 0,64 & 0,62 & 0,63 & 0,66 & 0,73 & 0,72 & 0,77 & 0,77 & 0,70 & $\mathbf{0 , 8 9}$ & 0,64 & 0,62 \\
\hline Relac6 & 0,67 & 0,62 & 0,63 & 0,61 & 0,73 & 0,74 & 0,75 & 0,80 & 0,75 & 0,76 & $\mathbf{0 , 8 9}$ & 0,65 & 0,67 \\
\hline Relac7 & 0,74 & 0,66 & 0,67 & 0,66 & 0,77 & 0,77 & 0,75 & 0,79 & 0,82 & 0,78 & $\mathbf{0 , 9 2}$ & 0,70 & 0,72 \\
\hline Satisf2 & 0,62 & 0,55 & 0,60 & 0,54 & 0,67 & 0,56 & 0,58 & 0,58 & 0,60 & 0,60 & 0,60 & 0,93 & 0,83 \\
\hline Satisf3 & 0,68 & 0,62 & 0,64 & 0,61 & 0,73 & 0,62 & 0,66 & 0,65 & 0,69 & 0,67 & 0,71 & 0,94 & 0,86 \\
\hline Satisf4 & 0,71 & 0,65 & 0,68 & 0,64 & 0,75 & 0,65 & 0,67 & 0,69 & 0,69 & 0,69 & 0,74 & 0,93 & 0,80 \\
\hline Leal1 & 0,73 & 0,68 & 0,70 & 0,67 & 0,79 & 0,67 & 0,70 & 0,70 & 0,72 & 0,69 & 0,75 & 0,86 & 0,94 \\
\hline Leal2 & 0,57 & 0,52 & 0,53 & 0,52 & 0,66 & 0,53 & 0,57 & 0,60 & 0,60 & 0,57 & 0,61 & 0,79 & 0,92 \\
\hline
\end{tabular}


Tabela 31

Estatística HTMT para o modelo final

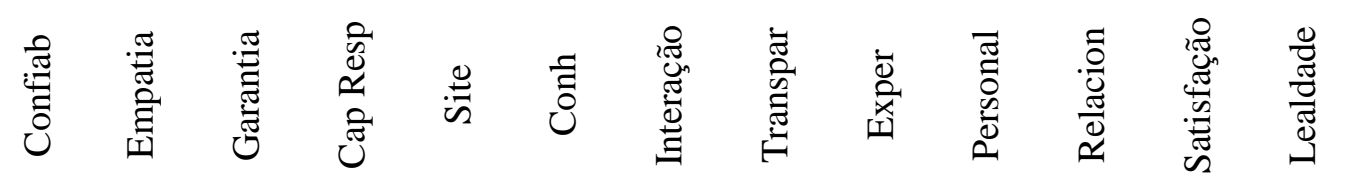

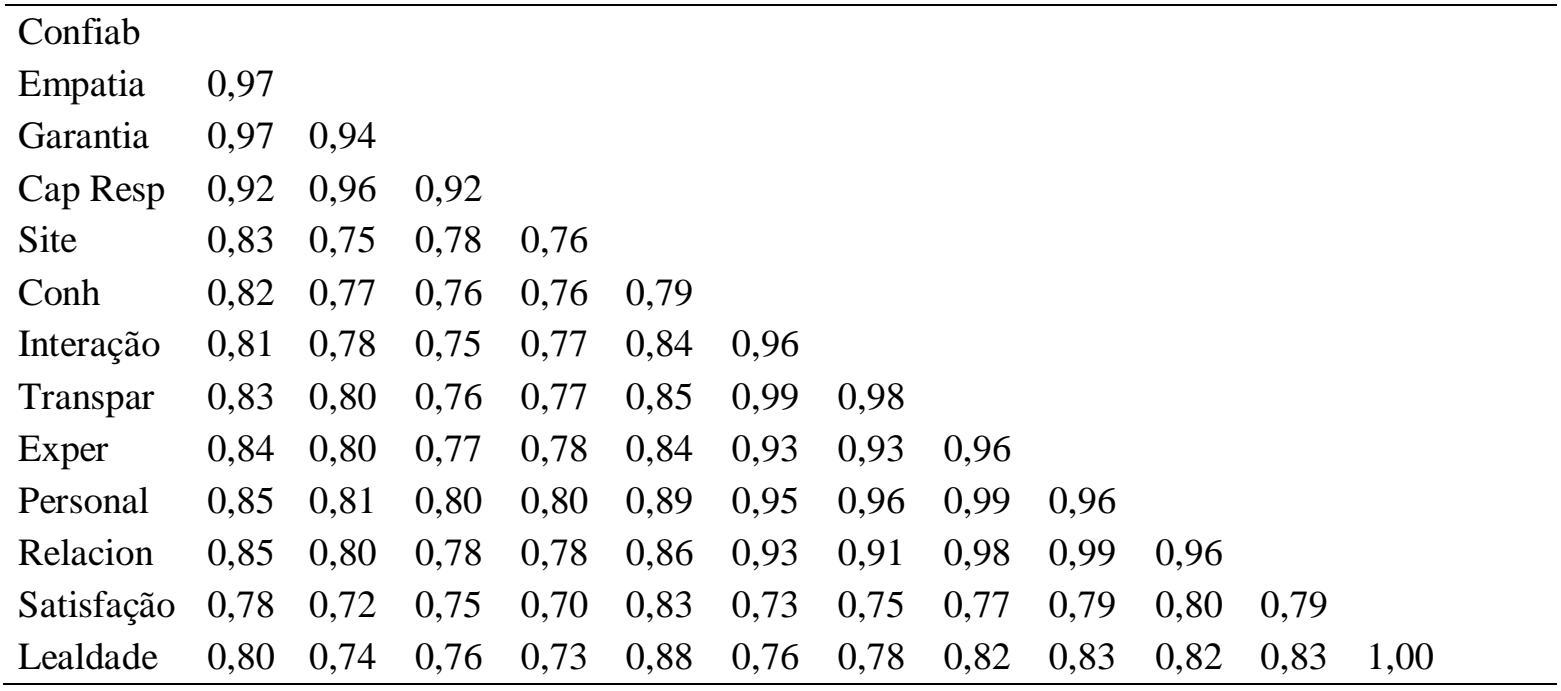

Nota. Elaborado pela autora. $\mathrm{N}=400$

Tabela 32

Medidas de validade convergente e confiabilidade dos indicadores para o modelo final

\begin{tabular}{lccc}
\hline & Alpha de Cronbach & $\begin{array}{c}\text { Confiabilidade } \\
\text { Composta }\end{array}$ & AVE \\
\hline Confiabilidade & 0,904 & 0,940 & 0,838 \\
Empatia & 0,885 & 0,945 & 0,896 \\
Garantia & 0,911 & 0,937 & 0,789 \\
Capacidade de Resposta & 0,916 & 0,947 & 0,857 \\
Site & 0,928 & 0,949 & 0,822 \\
Conhecimento & 0,858 & 0,914 & 0,779 \\
Interação & 0,895 & 0,935 & 0,827 \\
Transparência & 0,859 & 0,914 & 0,781 \\
Experiência & 0,870 & 0,920 & 0,794 \\
Personalização & 0,808 & 0,886 & 0,723 \\
Relacionamento & 0,920 & 0,944 & 0,807 \\
Satisfação & 0,925 & 0,952 & 0,870 \\
Lealdade & 0,845 & 0,928 & 0,866 \\
\hline
\end{tabular}

Nota. Elaborado pela autora. $\mathrm{N}=400$ 
